UNIVERSIDADE ESTADUAL PAULISTA “JÚLIO DE MESQUITA FILHO” FACULDADE DE CIÊNCIAS AGRONÔMICAS

CAMPUS DE BOTUCATU

\title{
ESCOAMENTO SUPERFICIAL E RISCO DE EROSÃO DO SOLO NA SUB-BACIA JARDIM NOVO HORIZONTE, MUNICÍPIO DE ILHA SOLTEIRA-SP
}

\author{
CARLA DEISIANE DE OLIVEIRA COSTA
}

Dissertação apresentada à Faculdade de Ciências Agronômicas da UNESP - Campus de Botucatu, para obtenção do título de Mestre em Agronomia (Irrigação e Drenagem).

BOTUCATU - SP

Fevereiro - 2010 
UNIVERSIDADE ESTADUAL PAULISTA “JÚLIO DE MESQUITA FILHO” FACULDADE DE CIÊNCIAS AGRONÔMICAS

CAMPUS DE BOTUCATU

\section{ESCOAMENTO SUPERFICIAL E RISCO DE EROSÃO DO SOLO NA SUB-BACIA JARDIM NOVO HORIZONTE, MUNICÍPIO DE ILHA SOLTEIRA-SP}

\section{CARLA DEISIANE DE OLIVEIRA COSTA}

Engenheira Agrônoma

Orientador: Prof. Dr. Antônio de Pádua Sousa

Co-Orientadora: $\operatorname{Prof}^{\mathrm{a}}$. Dr ${ }^{\mathrm{a}}$. Marlene Cristina Alves

Dissertação apresentada à Faculdade de Ciências Agronômicas da UNESP - Campus de Botucatu, para obtenção do título de Mestre em Agronomia (Irrigação e Drenagem).

BOTUCATU - SP

Fevereiro - 2010 


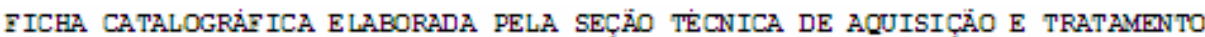
DA INEORMAÇÄO - SERVIÇO TÉCNICO DE BIBLIOTECA E DOCUMENTAÇẢ́ UNNESP - FCA LAGEADO - BOTUCATU (SP)

Costa, Carla Deisiane de Oliveira, 1984-

C837e Escoamento superficial e risco de erosão do solo na subbacia Jardim Novo Horizonte, Município de I Lha Solteira-SP / Carla Deisiane de Oliveira Costa. - Botucatu, [s.n.], 2010.

v, 88 f.: il., color., grafs., tabs.

Dissertação (Mestrado) -Universidade Estadual Paulista, Faculdade de Ciências Agronômicas, Botucatu, 2010

Orientador: Antônio de Pádua Sousa

Co-orientador: Marlene Cristina Alves

Inclui bibliografia

1. Uso e manejo do solo. 2. Propriedades físicas. 3. Degradação do solo. 4. Suscetibilidade à erosão. I. Sousa, Antônio de Pádua. II. Alves, Marlene Cristina, III. Universidade Estadual Paulista "Júlio de Mesquita Filho " (Campus de Botucatu). Faculdade de Ciências Agronômicas. TV. Título. 


\section{UNIVERSIDADE ESTADUAL PAULISTA "JÚLIO DE MESQUITA FILHO"}

FACULDADE DE CIÊNCIAS AGRONÔMICAS

CAMPUS DE BOTUCATU

\section{CERTIFICADO DE APROVAÇÃO}

TíTULO: "ESCOAMENTO SUPERFICIAL B RISCO DE BROSÃo DO SOLO NA SUB-BACIA JARDIM NOVO HORIZONTE, MUNICf́PIO DE ILHA SOLTEIRA-SP"

ALUNA: CARLA DEISIANE DE OLIVEIRA COSTA

ORIENTADOR: PROF. DR. ANTÔNIO DE PÁDUA SOUSA

CO-ORIENTADORA: PROF DRa MARLENE CRISTINA ALVES

Aprovado pela Comissão Examinadora

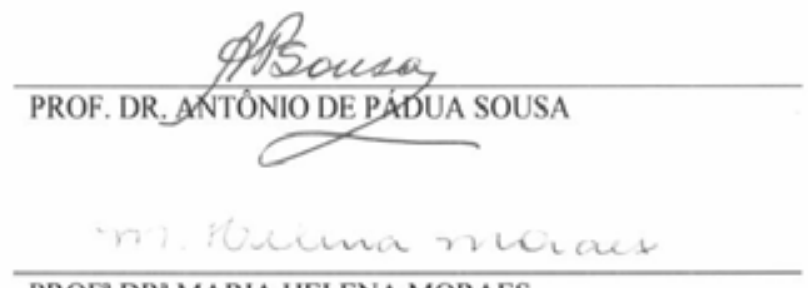

PROF DR" MARIA HELENA MORAES

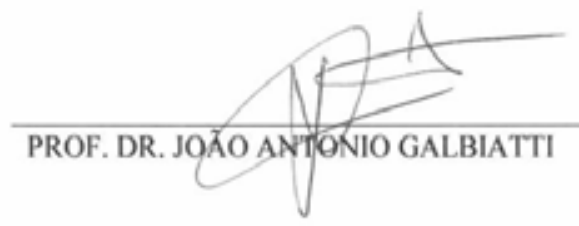

Data da Realização: 05 de Fevereiro de 2010. 
Senhor...

"A terra é vasta e pode sustentar a todos.

O próprio deserto, cuja aridez parece,

implacavelmente, estéril, pode fazer brotar a vida.

Basta que o domemos, carinhosamente.

Mas não basta, Senhor, tratar a terra,

preservá-la da erosão,

que corrói suas entranhas,

cicatrizar seus ferimentos,

para que ela produza mais frutos,

se a colheita é feita por aqueles

que jamais semearam.

Milhares de homens padecem de fome.

Será que a terra lhe nega o pão, mostrando-se insensível aos seus desesperados apelos?

Senhor, dai-me a necessária flexibilidade

de sentimentos para que eu seja generoso

como a seiva que sobe

e alimenta a planta.

E que a semente depositada

sobre meu coração germine,

cresça e frutifique abundantemente".

Oração do Agrônomo

(Eng. M. A. Manfio) 
A Deus pela presença constante em minha vida, sempre me auxiliando e me dando força nas horas mais difícies.

OFEREÇO

Aos meus queridos...

Pais, Dinorá e José Carlos, por mostrar que tudo é possível desde que tenhamos garra e determinação para vencer os obstáculos.

Às minhas irmãs, Cristiane e Juliane, por estarem sempre ao meu lado torcendo por mim. 


\section{AGRADECIMENTOS}

A toda minha família, pelo apoio e incentivo constantes, por acreditar e torcer por mim durante todo este tempo.

Ao Prof. Dr. Antônio de Pádua Sousa, pela orientação prestada no desenvolvimento deste trabalho, e pela confiança e amizade doada durante o curso.

À Prof ${ }^{\mathrm{a}}$. Dr ${ }^{\mathrm{a}}$. Marlene Cristina Alves, pela co-orientação e preciosas sugestões para a realização deste trabalho, e acima de tudo pela sua amizade a mim presenteada, e pelo incentivo para prosseguir em busca de meus objetivos.

À Prof ${ }^{\mathrm{a}}$. Dr ${ }^{\mathrm{a}}$. Martha M. Mischan pelo auxilio na análise estatística dos dados.

Ao Prof. Dr. Eduardo L. Díaz da Universidad Nacional de Entre Rios (UNER-Argentina), pela atenção e apoio dispensados na utilização do programa computacional SIMHUNER.

A Capes pela concessão da bolsa de estudos.

À Faculdade de Ciências Agronômicas de Botucatu - UNESP, bem como aos docentes da mesma, pela possibilidade de realização do curso de Mestrado.

À Faculdade de Engenharia de Ilha Solteira - UNESP nas pessoas de Valdivino dos Santos e Jean Fernando dos Santos Sousa, técnicos do Laboratório de Física do Solo, pelo auxílio no laboratório e nas coletas de campo, possibilitando a realização desta pesquisa.

A todos os amigos da pós-graduação, em especial à Angélica Cristina Fernandes Deus e Deise Paula da Silva, pelo convívio, apoio, companheirismo e amizade. Às amigas, Michele Cláudia da Silva e Adriana Avelino Santos, pela carinhosa recepção em sua casa durante a realização deste trabalho.

A todos aqueles que me ajudaram, de alguma forma, a realizar este sonho. Não é possível citar todos os nomes, mas essas pessoas sabem o quanto são especiais. 


\section{SUMÁRIO}

Página

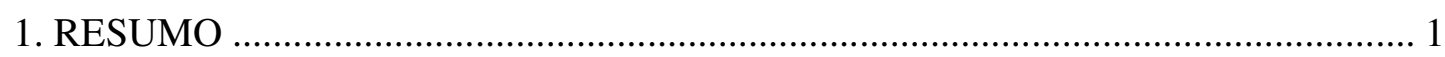

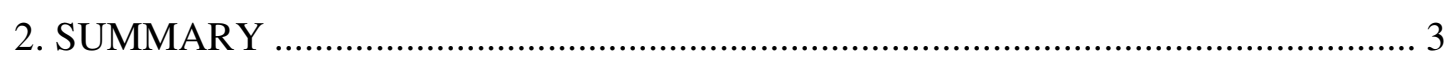

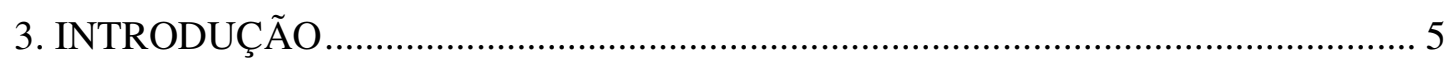

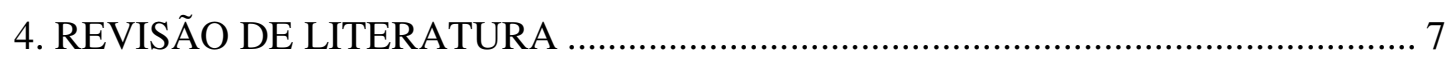

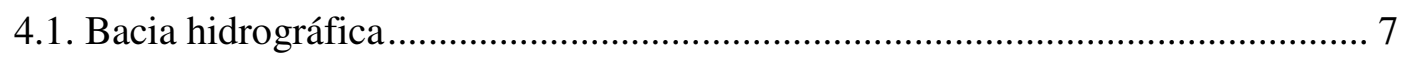

4.2. Propriedades do solo e a suscetibilidade à erosão ............................................. 8

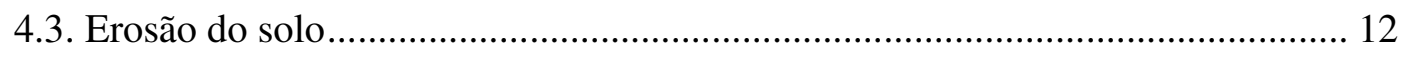

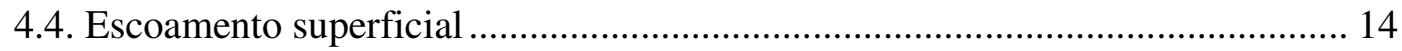

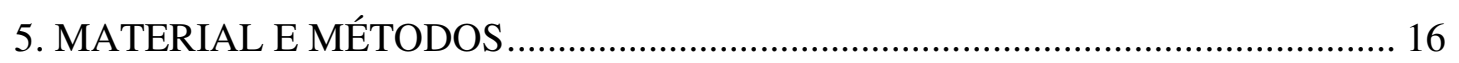

5.1. Localização e caracterização da área ................................................................ 16

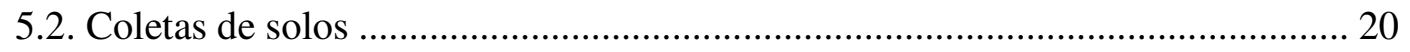

5.3. Descrição dos usos e ocupações do solo............................................................... 24

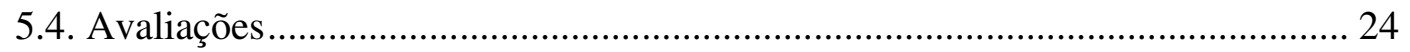

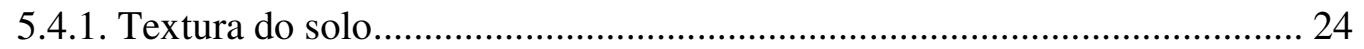

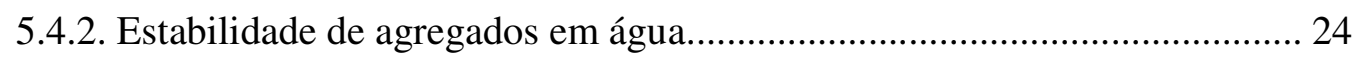

5.4.3. Porosidade total, macroporosidade e microporosidade............................. 25

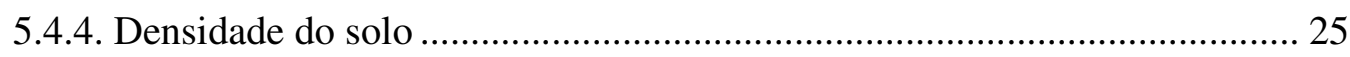

5.4.5. Infiltração e condutividade hidráulica do solo ......................................... 25

5.4.6. Variação de armazenamento de água no solo ............................................ 28

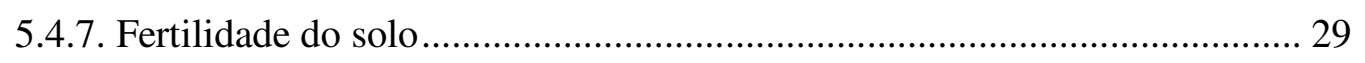

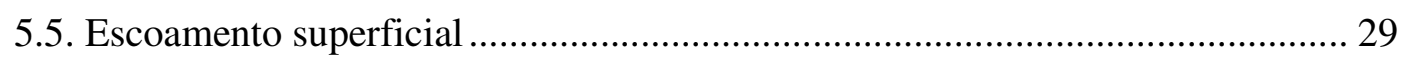

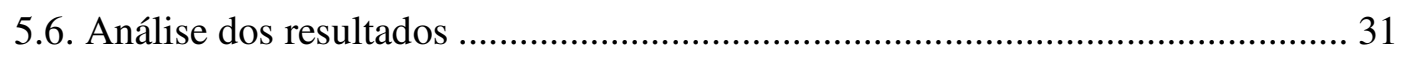

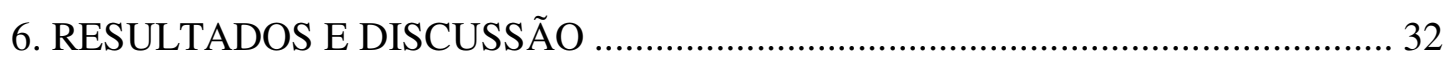

6.1. Propriedades físicas e químicas dos solos ........................................................ 32

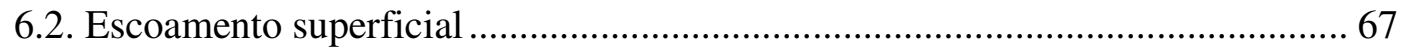

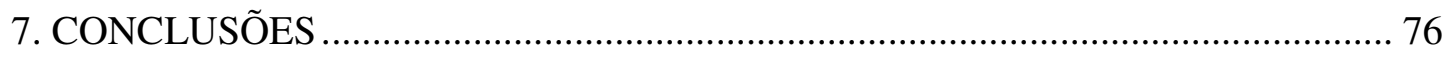

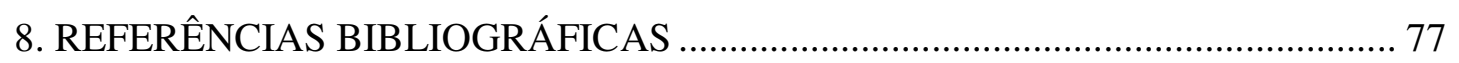

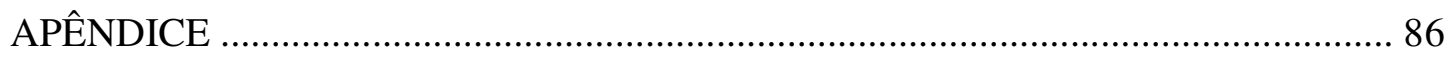




\section{RESUMO}

A Sub-Bacia Jardim Novo Horizonte está localizada no município de Ilha Solteira, noroeste do Estado de São Paulo. Esta região apresenta graves problemas ambientais, como erosão do solo e assoreamento dos rios, além da escassez de vegetação nativa. As classes de solos presentes na Sub-Bacia são o Latossolo Vermelho e o Argissolo Vermelho-Amarelo. A presente pesquisa foi realizada com o objetivo de estudar algumas propriedades físicas que interferem na dinâmica da água nos solos da Sub-Bacia Jardim Novo Horizonte, a capacidade de drenagem da Sub-bacia e o escoamento superficial, para o conhecimento dos locais de risco de erosão e de degradação do solo. Foram realizadas análises físicas e químicas dos solos sob diferentes usos e manejos. A coleta de solo foi realizada em dez locais ao longo da Sub-Bacia, sendo sete localizados no Latossolo e três no Argissolo, cada local amostrado constou de cinco repetições. No Latossolo foram amostrados os usos: cultura da manga, quatro locais com pastagem, cultura anual e vegetação degradada com pequenos fragmentos de vegetação nativa em área de transição entre o Latossolo e o Argissolo. No Argissolo foram amostrados os usos: dois locais com pastagem e cultura anual. Os resultados das propriedades físicas, químicas e relacionadas à dinâmica da água nos solos foram submetidos à análise conjunta para cada classe de solo e teste de Tukey, sendo utilizado o programa computacional SAS. A simulação do escoamento superficial foi realizada utilizando-se o programa computacional SIMHUNER. Constatou-se a partir dos dados obtidos que a degradação de algumas propriedades físicas e químicas do Latossolo pelo uso e manejo causa maior risco de erosão para a Sub-bacia Jardim 
Novo Horizonte. As taxas de infiltração da água nos solos moderadas e rápidas promovem baixo escoamento superficial. A Sub-Bacia estudada apresentou boa capacidade de drenagem e baixo escoamento superficial, porém devido à degradação de algumas propriedades dos solos que afetam a dinâmica da água neste, sobretudo no Latossolo, algumas áreas apresentam risco de erosão.

Palavras-chave: Uso e manejo do solo, propriedades físicas, degradação do solo, suscetibilidade à erosão. 
SURFACE RUNOFF AND SOIL EROSION RISK IN THE SUB-WATERSHED JARDIM NOVO HORIZONTE, ILHA SOLTEIRA-SP, BRAZIL. Botucatu, 2010. 88 p. Dissertação (Mestrado em Agronomia/Irrigação e Drenagem) - Faculdade de Ciências Agronômicas, Universidade Estadual Paulista.

Author: CARLA DEISIANE DE OLIVEIRA COSTA

Adviser: ANTÔNIO DE PÁDUA SOUSA

Co-Adviser: MARLENE CRISTINA ALVES

\section{SUMMARY}

The sub-watershed Jardim Novo Horizonte is located in Ilha Solteira-SP, Brazil, in the northeast of São Paulo State. This region shows grave environment problems, such as soil erosion and river sedimentation, as well as few native forests. Soils in the sub-watershed are classified as Red Oxisol and Red-Yellow Alfisol. This research had the objective of studying soil physical attributes that affect water dynamics, drainage capacity of the sub-watershed and surface runoff in the sub-watershed Jardim Novo Horizonte, contributing to identify areas of erosion risk and soil degradation. Soil physical and chemical properties were evaluated under different cropping systems. Sampling took place in ten spots along the sub-watershed. Seven and three samples were taken from the Oxisol and Alfisol, respectively. Five replications were evaluated for each place. The following systems were sampled from the Oxisol: area cropped with mango, four areas under pasture, area with annual crop and degraded area with fragments of native forest in a transition between the Oxisol and the Alfisol. Two places under pasture and annual crop were sampled in the Alfisol. Results of physical and chemical attributes, as well as water dynamics in soil, were submitted to combined analysis for each soil class and to the Tukey test, using the SAS program. The simulation of surface runoff was carried through using the SIMHUNER program. Physical and chemical degradation of the Oxisol, caused by soil use and management, lead to higher erosion risk in the sub-watershed Jardim Novo Horizonte. Moderate and higher rates of water infiltration in soil cause low surface runoff. The sub-watershed showed good drainage capacity and low surface runoff. However, some regions 
were more susceptible to erosion due to degradation of some soil attributes that affect water dynamics, mostly in the Oxisol.

Keywords: Soil use and management, physical properties, soil degradation, susceptibility to erosion. 


\section{INTRODUÇÃO}

A falta de planejamento ambiental e a ocupação inadequada de bacias hidrográficas vem causando a degradação dos recursos naturais, principalmente do solo e da água. Com o problema da escassez de água, associado à falta de planejamento ambiental, a bacia hidrográfica tem se tornado uma importante unidade de estudo.

É considerada por muitos autores como sendo uma das melhores unidades para o planejamento e o desenvolvimento sócio-econômico. A escolha por uma bacia hidrográfica como local de estudo deve-se ao fato de ser esta uma unidade onde se tem diferentes características. Apresentam regiões altas, onde estão ligadas as nascentes dos riachos e dos córregos, áreas de encosta onde as águas correm com maior velocidade, e as áreas de baixadas onde são observadas as consequências do manejo inadequado.

Um dos principais aspectos de uma bacia hidrográfica é a inter-relação existente entre os seus vários componentes, como o solo, a água, a cobertura vegetal e a atmosfera, sendo que uma ação qualquer sobre um deles certamente reflete-se nos outros. A ação antrópica rompe o equilíbrio existente entre estes componentes, causando principalmente, o aumento do escoamento superficial e da erosão, o transporte e o acúmulo de sedimentos nos cursos de água, e o assoreamento e a contaminação dos cursos de água.

É importante compreender os fatores que integram o processo de erosão do solo, pois serve como parâmetro na elaboração de medidas que visem maximizar o 
uso dos recursos naturais disponíveis e evitar os efeitos negativos decorrentes da produção, transporte e deposição de sedimentos.

Estes fatores dependem da natureza dos solos, ou seja, das suas propriedades, e principalmente do manejo, do uso e da ocupação dos mesmos. Dentre estas propriedades do solo que podem ser alteradas, estão suas propriedades físicas. O reconhecimento, a caracterização e o estudo destas propriedades são de grande importância para o equacionamento do uso do solo e para a compreensão dos fenômenos que possam ameaçar o ambiente, desta forma, colaborando para a sustentabilidade do sistema.

Dentre as propriedades do solo que sofrem tais modificações, está a estrutura, e consequentemente, a infiltração, a condutividade hidráulica e o armazenamento de água no solo. Os fatores que influenciam na movimentação e na retenção da água no solo interferem também no escoamento superficial resultante, uma vez que determina maior ou menor escoamento.

A Sub-Bacia Jardim Novo Horizonte, localizada no município de Ilha Solteira no noroeste do Estado de São Paulo, apresenta grande importância, pois está localizada nas proximidades da Usina Hidrelétrica de Ilha Solteira. Esta região apresenta graves problemas ambientais, como erosão do solo e assoreamento dos rios, além da escassez de vegetação nativa. Todos estes problemas foram ocasionados pela falta de planejamento ambiental e pelo manejo inadequado dos recursos naturais.

O presente trabalho foi realizado com o objetivo de estudar algumas propriedades físicas que interferem na dinâmica da água nos solos da Sub-Bacia Jardim Novo Horizonte, a capacidade de drenagem da Sub-bacia e o escoamento superficial, para o conhecimento dos locais de risco de erosão e de degradação do solo. 


\section{REVISÃO DE LITERATURA}

\subsection{Bacia hidrográfica}

Uma bacia hidrográfica é definida como uma área fisiográfica drenada por um curso ou cursos de água conectados, que convergem direta ou indiretamente para um leito ou espelho de água. Uma bacia hidrográfica é separada uma da outra por uma linha divisória, chamada de divisor de água, cada chuva que cai a partir desse ponto se dirige ao curso de água principal.

A dinâmica da água em uma bacia hidrográfica é marcada por vários componentes, sendo a precipitação o componente de entrada do ciclo hidrológico (SILVEIRA, 2001). A chuva ao atingir a superfície do solo, sofre dissipação, com uma parcela sendo retida pela cobertura vegetal (interceptação), outra parcela infiltrando-se no solo e o excedente escoando pela superfície (escoamento superficial). As plantas, juntamente com a própria superfície do solo, lagos e rios, transferem para a atmosfera grandes volumes de água na forma de vapor, sendo este um componente de saída do ciclo hidrológico conhecido como evapotranspiração (RIGHETTO, 1998).

As bacias hidrográficas constituem ecossistemas adequados para avaliação dos impactos causados pela atividade antrópica, que pode ocasionar sérios riscos ao seu equilíbrio (RANZINI, 2006). Os estudos em bacias são fundamentais para o entendimento da dinâmica da água e suas consequências ambientais, por constituírem elementos que 
proporcionam uma completa visão do ambiente solo, água e vegetação, e os efeitos do uso e manejo do solo na sustentabilidade do sistema e do ciclo hidrológico (AVANZINI, 2005).

O comportamento do ciclo hidrológico em uma bacia é definido por certas condições, como precipitação, tipos de solos, características geomorfológicas e geológicas. As atividades humanas que ocorrem em bacias hidrográficas (rurais ou urbanas) provocam a longo prazo alterações expressivas na dinâmica da água, levando à redução dos níveis dos corpos de água pelo assoreamento, que é gerado pela combinação de chuvas de elevada intensidade e manejo inadequado dos solos, que facilita a ação erosiva. Uma série de outros problemas advindos desta cadeia de atividades mal planejadas pode levar ao secamento completo de algumas sub-bacias (MELLO, 2003).

Uma bacia hidrográfica pode ser constituída por mais de um tipo de solo e de atividades agrícolas. A variação do solo, quando existir, tem como consequência, segundo Filizola et al. (2006), um funcionamento diferenciado dentro da mesma. Como unidade de estudo, tem proporcionado a percepção das diferenças nas concentrações e nos tipos de poluentes nas distintas formas de ocupação e de manejo do solo (GONÇALVES et al., 2005).

Nas áreas agrícolas, os solos e as plantas recebem agroquímicos, seja na forma de nutrientes ou de defensivos agrícolas, que podem permanecer no solo, serem absorvidos pelas plantas, serem carreados pelas águas superficiais, ou, ainda, lixiviados, atingindo as águas subterrâneas. As águas provenientes de pastos, além da contribuição da carga orgânica, tendem a aumentar o índice de coliformes fecais e de nutrientes nos cursos de água. Os despejos industriais, que podem ser encontrados tanto em áreas rurais como urbanas, também são considerados como fonte de contaminação dessas águas (FILIZOLA et al., 2006).

A preservação da qualidade ambiental em uma bacia hidrográfica é altamente desejável, não só ao bem estar e segurança do homem, como de todos os seres vivos que vivem em parceria naquela área (MAGRINI e SANTOS, 2001).

\subsection{Propriedades do solo e a suscetibilidade à erosão}

Nas últimas décadas, o aumento da produção agrícola e da produtividade, e as consequentes intensificações do uso do solo, trouxeram preocupações 
relacionadas aos impactos ambientais e à conservação dos recursos naturais a curto, médio e longo prazo (DUARTE et al., 2004).

$\mathrm{O}$ uso incorreto, pelo homem, dos recursos naturais, modificando o solo, cria condições para que o processo erosivo se intensifique. As condições mais favoráveis estão presentes em solos desprovidos de cobertura vegetal, compactados e recentemente movimentados por cultivos intensivos, trazendo como efeitos o aumento na desagregação desses solos, diminuição na capacidade de infiltração de água e, consequentemente, aumento do escoamento superficial (AVANZINI, 2005).

As propriedades do solo podem influenciar o processo erosivo, para Bertoni e Lombardi Neto (1990), o conhecimento destas propriedades é de grande importância na orientação dos trabalhos de manejo de solo e controle da erosão.

Dentre as propriedades físicas do solo, a textura é uma das mais importantes para o estudo da dinâmica da água no mesmo. A proporção entre as frações areia, silte e argila, que compõem a massa de um solo, se refere à textura do solo. As relações texturais entre camadas são importantes para caracterizar a dinâmica da água no seu perfil.

A textura exerce grande influência no volume de água que pode ser armazenado no solo, pois ela determina o tamanho, a quantidade e a continuidade dos poros. Geralmente solos com poros menores apresentam maior capacidade de armazenamento e retenção de água. Além disso, a textura influencia a movimentação de água no solo, para Brandão et al. (2009), ela é de extrema importância na condutividade hidráulica do mesmo. Em solos de textura grossa, com maior quantidade de poros grandes, apresentam maiores valores de condutividade hidráulica e taxa de infiltração.

Outra propriedade do solo que deve ser analisada para estudos diagnósticos de suscetibilidade a erosão, é a estabilidade de agregados em água. A estabilidade dos agregados caracteriza a resistência do solo à ruptura causada por agentes externos. Baixos índices de estabilidade de agregados podem aumentar a tendência de dispersão do solo, aumentando o escoamento superficial e o risco de erosão.

O uso intensivo do solo causa redução da estabilidade dos agregados, deixando-os mais suscetíveis aos processos erosivos. Para uma mesma classe de solo, diferentes práticas de manejo podem afetar distintamente as propriedades, incluindo os processos de agregação. $\mathrm{O}$ cultivo intensivo, aliado à alta taxa de revolvimento, é responsável 
pela redução do conteúdo de matéria orgânica do solo, que é um dos principais agentes de formação e estabilização dos agregados. Quanto maior for o agregado, maior será o seu diâmetro médio ponderado (DMP) e os espaços porosos entre agregados, aumentando a infiltração de água no mesmo e diminuindo a erosão (CASTRO FILHO et al., 1998).

Salton et al. (2008) ao estudarem a influência de diferentes sistemas de manejo sobre a estabilidade de agregados, observaram que os solos sob pastagens apresentaram agregados maiores que os solos com culturas anuais. Silva e Mielniczuk (1998) também obtiveram os mesmos resultados ao avaliarem a estabilidade de agregados sob diferentes sistemas de cultivo.

A porosidade do solo é uma propriedade que também deve ser analisada, pois exerce grande influência em outras propriedades, como a infiltração, a condutividade hidráulica, e o armazenamento de água no solo.

Curi et al. (1993) definem a porosidade total do solo como a porcentagem do volume do solo não ocupado por partículas sólidas, incluindo todo o espaço poroso ocupado pelo ar e água, respectivamente, a macroporosidade e a microporosidade. A macroporosidade é definida como o número de poros maiores, no caso aqueles que não são capazes de transportar água por capilaridade, enquanto que a microporosidade se refere aos poros capazes de exercer esta função.

O tamanho dos poros influi na movimentação e na retenção de água no solo, quanto menor for a porosidade total de um solo maior será o escoamento superficial e a erosão. As práticas de manejo do solo exercem influência em sua estrutura e, consequentemente, em sua porosidade. Alguns autores verificaram uma diferença entre a porosidade total em solos sob diferentes sistemas de uso e manejo, dentre eles citam-se Ceconi et al. (2007) e Matias et al. (2009) que observaram uma menor porosidade em solos com uso mais intensivo.

O conhecimento da condutividade hidráulica do solo também é de fundamental importância para a determinação do fluxo de água nos solos, bem como para a quantificação da erosão. Ela reflete a capacidade do mesmo em conduzir água. Quanto maior for o valor de condutividade, maior tende a ser a facilidade com que a água se movimenta no solo, sendo o valor máximo quando o solo está saturado (RIBEIRO, 2005). Segundo Silva (2003) a condutividade hidráulica é influenciada pela quantidade e qualidade de poros no solo. 
O solo que apresenta maior macroporosidade, que efetivamente permite a movimentação de água no solo, será mais condutivo em relação àquele com menor macroporosidade.

A infiltração de água no solo é uma das propriedades mais importantes de um solo, uma vez que a partir deste fenômeno físico pode-se estimar a capacidade de escoamento superficial do mesmo. Brandão et al. (2009) afirmam que, a taxa de infiltração de água no solo é um dos fatores que mais influencia o escoamento superficial. De acordo com Duarte et al. (2004), a infiltração de água no solo traz, como consequência, maior ou menor erosão, dependendo da declividade da bacia, que determina maior ou menor velocidade de escoamento de água superficial, associada à cobertura vegetal, classe de solo e uso da terra.

Em estudos de movimentação de água no solo alguns autores verificaram que o uso, o manejo e a classe de solo influenciam na sua taxa de infiltração. Dentre eles citam-se Pinheiro et al. (2009), que ao avaliarem a capacidade de infiltração de água nos solos sob diferentes usos e práticas de manejo, observaram que a capacidade de infiltração de água no solo foi superior nas áreas com culturas utilizando o plantio convencional, devido à movimentação do solo ocasionado por este sistema.

Queiroz (2008) estudando o comportamento da taxa de infiltração de água nos solos da Sub-Bacia Jardim Novo Horizonte, verificou que o Latossolo apresentou taxas constantes de infiltração menores quando comparadas com o Argissolo, devido à degradação de algumas propriedades físicas do Latossolo. Quanto ao uso do solo, o autor observou que, o uso do Latossolo é na sua maioria com pastagens e culturas anuais, e que, no caso das pastagens, foram encontradas baixas taxas constantes de infiltração devido à degradação das mesmas. Já para as áreas com culturas anuais, pelo fato de haver revolvimento do solo no momento do preparo, a taxa constante de infiltração foi maior do que nas áreas com pastagens.

Quanto ao armazenamento de água no solo, este depende da sua textura, estrutura, distribuição e tamanho médio dos poros, estando diretamente relacionado aos processos de escoamento superficial e erosão. Quanto maior for a capacidade de um solo em armazenar água, menor será o escoamento superficial deste solo. A capacidade de armazenamento de água de um solo é definida por Curi et al. (1993) como a porção de água presente no solo, em condições de ser absorvida pelas raízes das plantas, sendo normalmente 
considerada como o teor de água retida entre a capacidade de campo e o ponto de murcha permanente.

Com relação às propriedades químicas, solos com baixa fertilidade promovem menores índices de cobertura do solo, devido ao menor crescimento da vegetação, tendo como consequência, menor proteção da superfície do solo. Quanto menos cobertura tiver a superfície do solo, maior será a desagregação superficial do mesmo, devido ao impacto das gotas de chuva, e mais alta será a velocidade de escoamento.

O teor de matéria orgânica do solo também exerce grande relação com a suscetibilidade do mesmo à erosão. Os solos que apresentam teores mais elevados, apresentam maior capacidade de aglutinação de partículas, favorecendo a capacidade de retenção de água e infiltração. Além disso, elevados teores de matéria orgânica no solo contribuem para aumentar o tamanho dos agregados, tornando-os mais resistentes à dispersão e ao arraste (SILVA, 1990).

Queiroz (2008) ao estudar as propriedades químicas dos solos da SubBacia Jardim Novo Horizonte, verificou que o uso e o manejo do solo interferem no conteúdo de matéria orgânica deste. Além disso, o autor observou que o Argissolo apresentou melhores propriedades químicas em relação ao Latossolo, devido o Argissolo ser um solo naturalmente eutrófico, propiciando assim, um melhor desenvolvimento das plantas e, consequentemente, uma melhor cobertura vegetal para este solo.

\subsection{Erosão do solo}

Bertoni e Lombardi Neto (1990) especificam como erosão o processo de retirada e transporte de partículas do solo pelos agentes erosivos: água e vento, sendo um dos mais sérios fatores de degradação dos solos e também do meio ambiente, visto que, promove grandes consequências ecológicas.

Para Kirchner et al. (2006), a erosão é um processo natural dos solos que ocorre sobre todas as áreas, e é essencial para o desenvolvimento dos solos e paisagens. Entretanto, a erosão torna-se um problema quando é acelerada pela atividade humana, resultando em perda da camada superior dos solos. 
A erosão induzida pela atividade humana é o processo de desprendimento e de arraste das partículas do solo, e constitui a principal causa do depauperamento deste (BERTONI e LOMBARDI NETO, 1990).

A ação antrópica constitui o principal fator na deflagração dos processos erosivos acelerados. Avanzini (2005) complementa que, o homem modificando o ecossistema natural, vem provocando uma intensa degradação dos recursos naturais, sobretudo o solo, refletindo na deterioração do meio ambiente, causando o assoreamento dos cursos de água e redução da capacidade produtiva dos mesmos.

A erosão não é a mesma em todos os solos, as propriedades físicas, principalmente a textura, taxa de infiltração, permeabilidade, densidade do solo e a porosidade, exercem diferentes influências na resistência do solo à erosão (SILVA et al., 2007). Além disso, dentre os fatores do solo, que mais interferem no processo erosivo, estão ligados à declividade, à distância percorrida pelo escoamento superficial, a rugosidade superficial, a resistência do solo à ação erosiva da chuva e ao percentual de cobertura vegetal existente na ocasião do evento de precipitação (PEREIRA et al., 2003).

Para Silva et al. (2007), os danos causados pelas gotas de chuva que golpeiam a superfície do solo desprotegido, constituem o primeiro passo no processo de erosão, pois quando atingem a superfície do solo, rompem os grânulos e os torrões, reduzindoos a partículas menores, e com isso aumentam a proporção de partículas pequenas na superfície.

Essas partículas pequenas podem ser levadas ao longo do perfil, principalmente pela ação da água, no sentido vertical, preenchendo os espaços vazios entre os agregados, diminuindo a capacidade de infiltração de água, acelerando assim a erosão, pois induzem a um aumento do escoamento superficial (BERTONI e LOMBARDI NETO, 1990).

O transporte de partículas desagregadas sobre a superfície do solo se dá quando o solo está saturado ou quando a velocidade de água precipitada é superior a capacidade de infiltração de água no solo, ocasionando o escoamento do excesso de água (INÁCIO et al., 2007).

De forma geral, em uma bacia hidrográfica, nas porções mais altas ocorre maior erosão e transporte de sedimentos, o qual vai diminuindo à medida que as 
declividades decrescem (CARVALHO, 1994). E este material transportado, se deposita nos locais mais baixos da bacia (cursos de água) concluindo assim, o processo erosivo.

O fator cobertura sobre o solo é de grande importância na prevenção e no controle da erosão e no agravamento do processo erosivo. Sendo um fator que está intimamente ligado a processos antrópicos, os quais explicam o modo pelo qual vem sendo manejado o solo de uma área (SILVA et al., 2007).

A cobertura do solo reduz a ação direta do impacto das gotas de chuva sobre o solo. E, além disso, Ranieri et al. (1998) complementam que, a existência de vegetação também aumenta a rugosidade do terreno e a capacidade de infiltração de água, diminuindo a velocidade do escoamento superficial, favorecendo a absorção rápida da precipitação.

A erosão do solo e os consequentes impactos na produtividade agrícola, na qualidade da água e no assoreamento de cursos e reservatórios de água, são preocupações evidenciadas em todo o mundo, e embora diversas técnicas sejam disponíveis para controlar a erosão, a compreensão do complexo processo físico envolvido na erosão é fundamental para se disponibilizar medidas de controle mais práticas e econômicas (PRUSKI et al., 2001).

\subsection{Escoamento superficial}

O escoamento superficial é uma parcela importante na dinâmica da água em uma bacia hidrográfica (TUCCI, 2001). Pruski et al. (2001) complementa que, o escoamento superficial ocorre quando a intensidade da precipitação excede a velocidade de infiltração da água no solo.

Para a geração do escoamento superficial existem inúmeras variáveis e atributos físicos que determinam o processo, destacando-se as características da precipitação e da capacidade de infiltração de água no solo (TUCCI, 2001).

Em um evento de precipitação parte dela é interceptada pela vegetação, enquanto o restante atinge a superfície do solo. O empoçamento da água nas depressões existentes na superfície do solo começa a ocorrer somente quando a intensidade de precipitação excede a taxa de infiltração, ou quando a capacidade de acumulação de água no 
solo for ultrapassada. Esgotada a capacidade de retenção superficial, começa o escoamento superficial (PRUSKI et al., 2008).

Manejos inadequados que levam a compactação do solo provocam aumento da parcela do escoamento superficial, reduzindo, portanto, a presença de água no solo e, consequentemente, a recarga do lençol freático e nascentes, podendo conduzi-las a um processo irreversível de seca dos cursos de água (MELLO, 2003).

Para Pruski et al. (2001), o escoamento superficial é o principal processo associado à erosão hídrica, pois apesar do impacto das gotas de chuva desempenhar um papel importante na desagregação das partículas do solo, é o escoamento superficial que promove o transporte das partículas de solo liberadas.

O tamanho e a quantidade do material em suspensão arrastado pela água dependem da velocidade com que ela escorre, e essa velocidade é resultante do comprimento do lançante e do grau de declive (BERTONI e LOMBARDI NETO, 1990).

A topografia, além de influenciar a velocidade de escoamento de água no solo, interfere também no armazenamento de água sobre este, sendo as áreas mais declivosas geralmente com menor capacidade de armazenamento superficial do que as mais planas (PRUSKI et al., 2008).

O mesmo autor salienta que, a cobertura vegetal e os tipos de uso do solo, além de seus efeitos sobre as condições de infiltração da água no solo, exercem importante influência na interceptação da água advinda da precipitação. Quanto maior a porcentagem de cobertura vegetal e de rugosidade da superfície do solo, menor o escoamento superficial.

Além do aspecto hidrológico do escoamento superficial, é igualmente importante analisar como o teor de água antecedente pode influenciar a perda de solo na bacia hidrográfica. A erodibilidade do solo é função, além das propriedades físicas e químicas dos solos, das condições hidrológicas, notadamente, do teor de água no solo. Portanto, para um mesmo evento de precipitação, mantendo todas as condições de manejo e de cobertura vegetal da bacia, diferenças em perdas de solo podem ser explicadas pelas condições hidrológicas reinantes (MELLO, 2003). 


\section{MATERIAL E MÉTODOS}

\subsection{Localização e caracterização da área}

O trabalho foi realizado na Sub-Bacia Jardim Novo Horizonte, que está localizada no município de Ilha Solteira, noroeste do Estado de São Paulo (Figura 1), possui 2.200 ha de área, as coordenadas geográficas são $20^{\circ} 25^{\prime}$ de latitude Sul e 51 $1^{\circ} 15^{\prime}$ de longitude Oeste de Greenwich e altitude média de 320 metros.
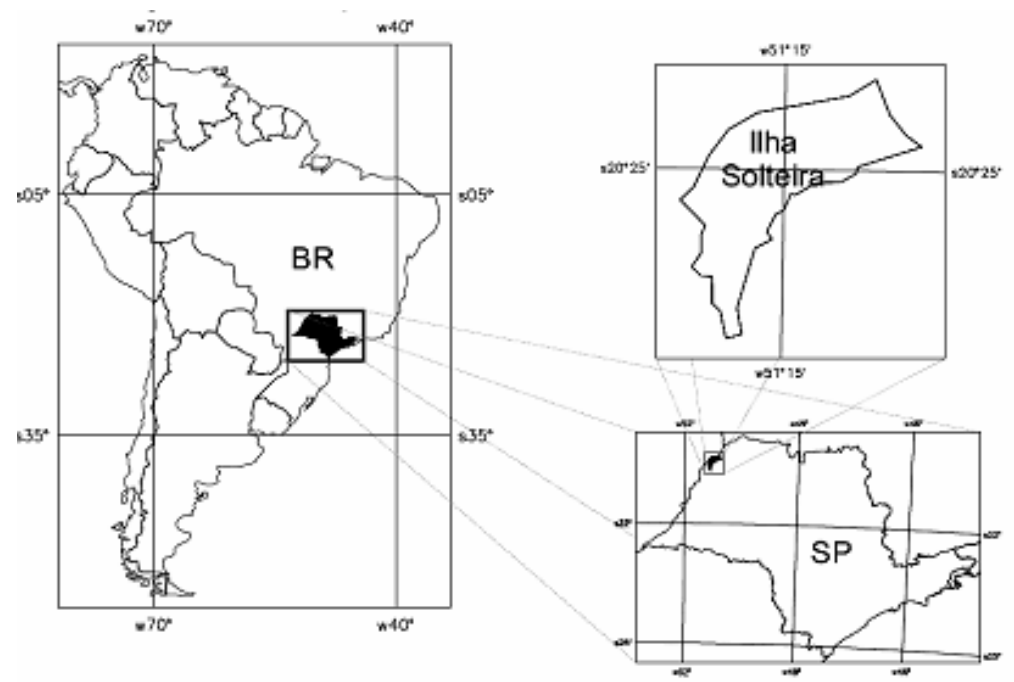

Figura 1. Mapa da localização do município de Ilha Solteira, noroeste do Estado de São Paulo (QUEIROZ, 2008). 
A classificação climática da região, de acordo com Köppen, é do tipo Aw, definido como tropical úmido com estação chuvosa no verão e seca no inverno. A temperatura média anual é de $23^{\circ} \mathrm{C}$, a precipitação pluvial média é de $1.370 \mathrm{~mm}$ e a umidade relativa do ar média anual está entre $70 \%$ e $80 \%$. A vegetação original da região é de Cerrado.

De acordo com o Mapa Pedológico do Estado de São Paulo (OLIVEIRA, 1999; OLIVEIRA et al., 1999) os solos mais representativos da Sub-Bacia Jardim Novo Horizonte são: Latossolo Vermelho distrófico e Argissolo Vermelho-Amarelo eutrófico, representando 70\% e 30\% da área total, respectivamente (Figura 2).

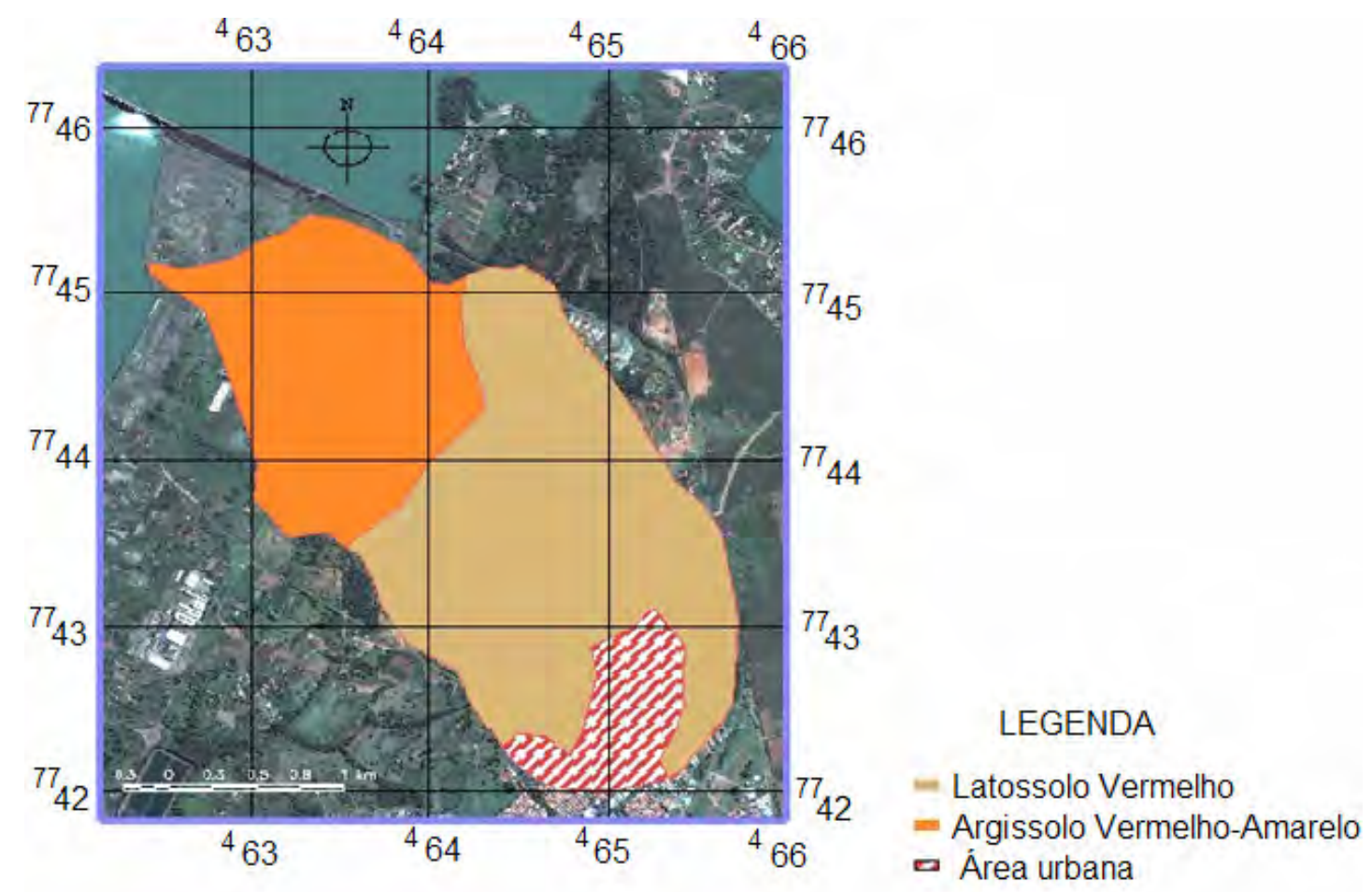

Figura 2. Mapa Pedológico da Sub-Bacia Jardim Novo Horizonte, Ilha Solteira, SP (QUEIROZ, 2008).

A Sub-Bacia em estudo apresenta drenagem do tipo dendrítica, e segundo a classificação de Sthraler (1957) é de terceira ordem de ramificação. Em sua foz encontram-se áreas onde a água perene passa a ser canalizada, alguns elementos, como a nascente da Sub-Bacia, não se encontra em suas condições naturais e já está totalmente antropotizada (QUEIROZ, 2008) (Figura 3). 


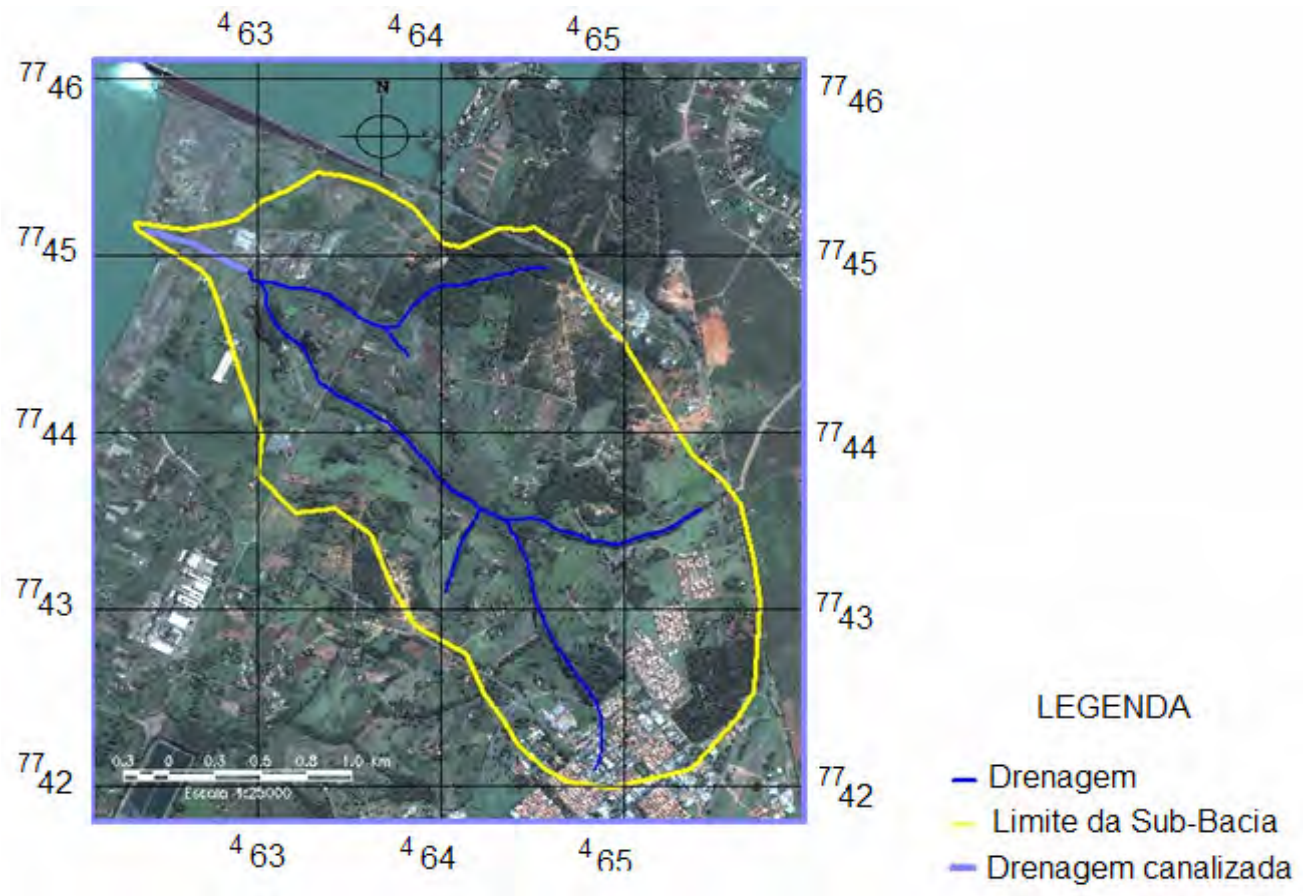

Figura 3. Mapa de drenagem da Sub-Bacia Jardim Novo Horizonte, Ilha Solteira, SP (QUEIROZ, 2008).

O perfil longitudinal da Sub-Bacia se apresenta com relevo ondulado, característica de drenagem dendrítica, com as seguintes altitudes: a menor de $280 \mathrm{~m}$ e a maior com 370 m (Figura 4).

Perfil Longitudional

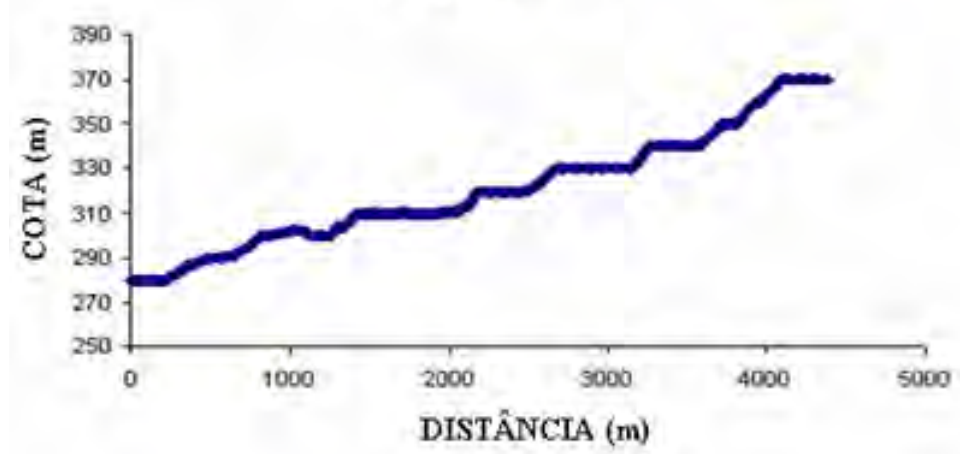

Figura 4. Gráfico do perfil longitudinal da Sub-Bacia Jardim Novo Horizonte, Ilha solteira, SP (QUEIROZ, 2008). 
As classes de uso e de ocupação dos solos da Sub-Bacia em estudo, e as áreas de ocupação encontram-se na Tabela 1 e estão representadas na Figura 5 (QUEIROZ, 2008).

Tabela 1. Classes de uso e de ocupação dos solos da Sub-Bacia Jardim Novo Horizonte, Ilha Solteira, SP (QUEIROZ, 2008).

\begin{tabular}{|c|c|}
\hline Classes temáticas & Área total $(\%)$ \\
\hline Vegetação antrópica/edificação & 10,80 \\
\hline Vegetação natural ciliar & 3,82 \\
\hline Pastagem & 49,68 \\
\hline Vegetação natural & 19,41 \\
\hline Área urbana & 10,60 \\
\hline Área de propriedade da CESP & 1,90 \\
\hline Corpo d'água & 2,38 \\
\hline Área degradada & 1,41 \\
\hline Total & 100,00 \\
\hline
\end{tabular}

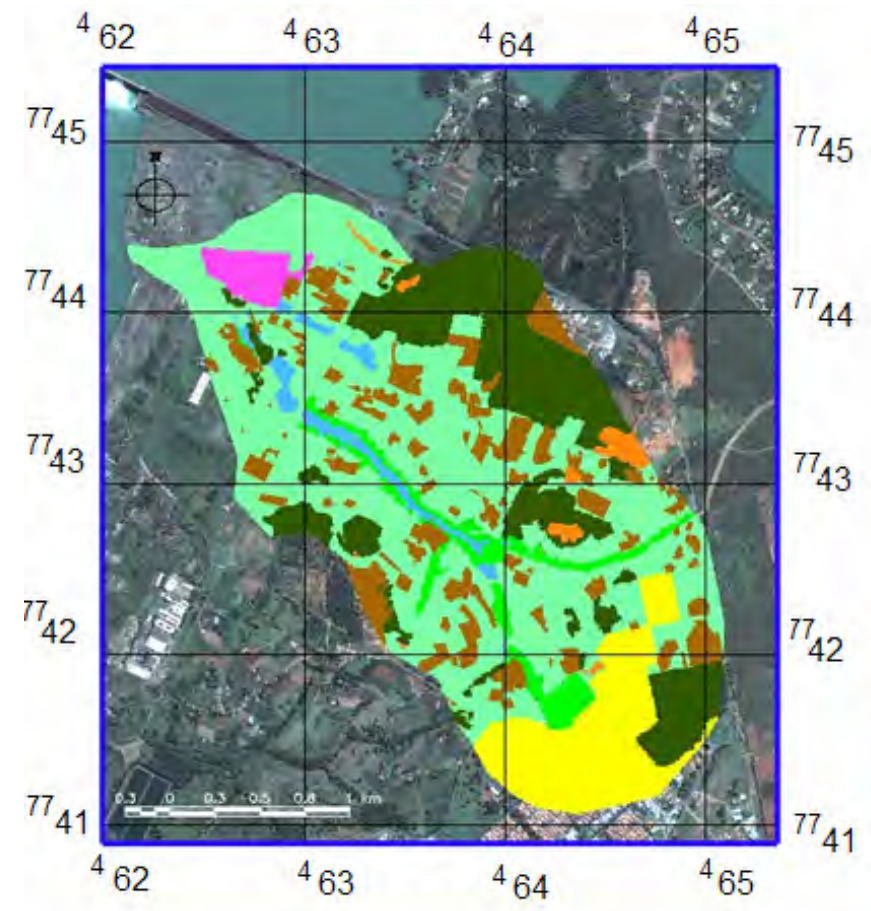

\footnotetext{
LEGENDA

- Vegetação Antrópica/Edificação

- Vegetação natural ciliar

- Pastagem

- Vegetaçäo natural

Area_Urbana

- Área da propriedade da Cesp

= Corbo de ádua

= Área degradada
}

Figura 5. Mapa de uso e de ocupação dos solos da Sub-Bacia Jardim Novo Horizonte, Ilha Solteira, SP (QUEIROZ, 2008). 


\subsection{Coletas de solos}

A coleta de solos foi realizada em dez locais ao longo da Sub-Bacia, sendo sete localizados no Latossolo Vermelho distrófico e três no Argissolo VermelhoAmarelo eutrófico, as quais foram feitas aleatoriamente, dentro de diferentes formas de uso e de ocupação dos solos (Figura 6).

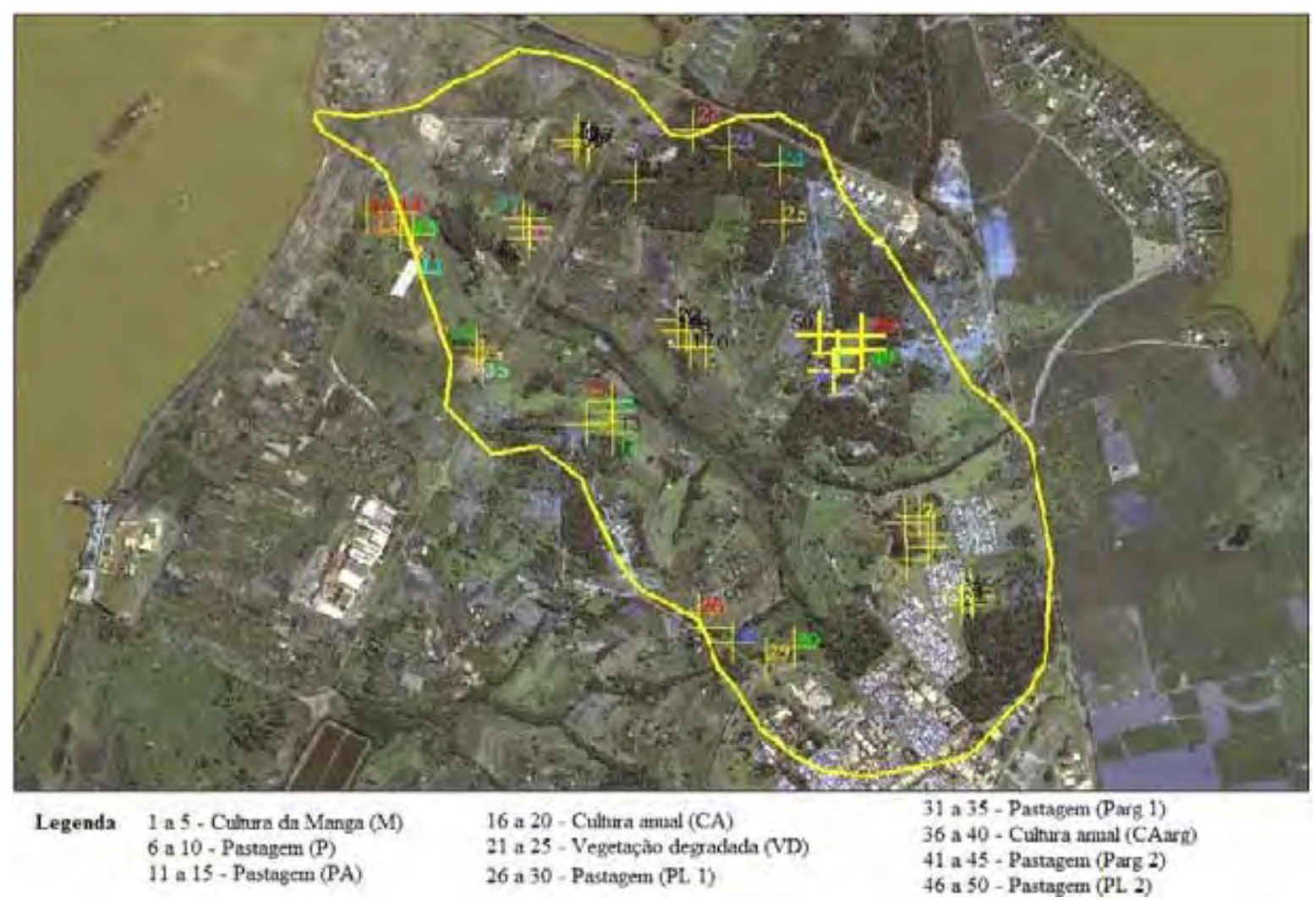

Figura 6. Localização dos pontos de coletas de solo e de avaliações de infiltração e de condutividade hidráulica dos solos.

Para cada local determinado foram coletadas amostras deformadas e indeformadas, nas camadas de 0 a 10 e de 10 a $20 \mathrm{~cm}$, em 5 pontos para a realização das análises, totalizando 100 amostras para cada atributo analisado. Nestes mesmos pontos, foram realizadas avaliações, no campo, de infiltração e de condutividade hidráulica dos solos. Cada ponto amostrado foi georreferenciado com o auxílio de um GPS (Sistema de Posicionamento Global), cujas coordenadas geográficas encontram-se na Tabela 2. 
Tabela 2. Localização dos pontos de coletas de solo e de avaliações de infiltração e de condutividade hidráulica, nas duas classes de solos sob diferentes formas de uso e de ocupação.

\begin{tabular}{|c|c|c|c|c|}
\hline \multirow[b]{2}{*}{ Classes de solos } & \multirow[b]{2}{*}{ Usos e ocupações dos solos } & \multirow[b]{2}{*}{ Pontos } & \multicolumn{2}{|c|}{ Coordenadas } \\
\hline & & & $\mathbf{S}$ & W \\
\hline \multirow{5}{*}{ Latossolo } & Cultura da Manga (M) & 1 & $20^{\circ} 24^{\prime} 44,4^{\prime \prime}$ & $51^{\circ} 19^{\prime} 54,4^{\prime \prime}$ \\
\hline & & 2 & $20^{\circ} 24 ' 45,3^{\prime \prime}$ & $51^{\circ} 19^{\prime} 56,2^{\prime \prime}$ \\
\hline & & 3 & $20^{\circ} 24^{\prime} 43,4^{\prime \prime}$ & $51^{\circ} 19^{\prime} 56,1^{\prime \prime}$ \\
\hline & & 4 & $20^{\circ} 24^{\prime} 42,7^{\prime \prime}$ & $51^{\circ} 19^{\prime} 54,9^{\prime \prime}$ \\
\hline & & 5 & $20^{\circ} 24^{\prime} 43,9^{\prime \prime}$ & $51^{\circ} 19^{\prime} 54,6^{\prime \prime}$ \\
\hline \multirow[t]{5}{*}{ Latossolo } & Pastagem $(\mathrm{P})$ & 1 & $20^{\circ} 24^{\prime} 32,4^{\prime \prime}$ & $51^{\circ} 20^{\prime} 04,7^{\prime \prime}$ \\
\hline & & 2 & $20^{\circ} 24^{\prime} 31,5^{\prime \prime}$ & $51^{\circ} 20^{\prime} 02.7^{\prime \prime}$ \\
\hline & & 3 & $20^{\circ} 24^{\prime} 38,3^{\prime \prime}$ & $51^{\circ} 20^{\prime} 04,6^{\prime \prime}$ \\
\hline & & 4 & $20^{\circ} 24^{\prime} 36,3^{\prime \prime}$ & $51^{\circ} 20^{\prime} 01,6^{\prime \prime}$ \\
\hline & & 5 & $20^{\circ} 24^{\prime} 34,1^{\prime \prime}$ & $51^{\circ} 20^{\prime} 00,8^{\prime \prime}$ \\
\hline \multirow[t]{5}{*}{ Latossolo } & Pastagem (PA) & 1 & $20^{\circ} 24^{\prime} 17,3^{\prime \prime}$ & $51^{\circ} 20^{\prime} 54,7^{\prime \prime}$ \\
\hline & & 2 & $20^{\circ} 24^{\prime} 18,5^{\prime \prime}$ & $51^{\circ} 20^{\prime} 50,7^{\prime \prime}$ \\
\hline & & 3 & $20^{\circ} 24^{\prime} 16,8^{\prime \prime}$ & $51^{\circ} 20^{\prime} 50,8^{\prime \prime}$ \\
\hline & & 4 & $20^{\circ} 24^{\prime} 15,2^{\prime \prime}$ & $51^{\circ} 20^{\prime} 50,4^{\prime \prime}$ \\
\hline & & 5 & $20^{\circ} 24^{\prime} 13,7^{\prime \prime}$ & $51^{\circ} 20^{\prime} 50,9^{\prime \prime}$ \\
\hline \multirow[t]{5}{*}{ Latossolo } & Cultura Anual (CA) & 1 & $20^{\circ} 24^{\prime} 05,3^{\prime \prime}$ & $51^{\circ} 20^{\prime} 36,2^{\prime \prime}$ \\
\hline & & 2 & $20^{\circ} 24^{\prime} 05,1^{\prime \prime}$ & $51^{\circ} 20^{\prime} 38,3^{\prime \prime}$ \\
\hline & & 3 & $20^{\circ} 24^{\prime} 02,7^{\prime \prime}$ & $51^{\circ} 20^{\prime} 39,1^{\prime \prime}$ \\
\hline & & 4 & $20^{\circ} 24^{\prime} 02,3^{\prime \prime}$ & $51^{\circ} 20^{\prime} 40,5^{\prime \prime}$ \\
\hline & & 5 & $20^{\circ} 24^{\prime} 01,0^{\prime \prime}$ & $51^{\circ} 20^{\prime} 40,6^{\prime \prime}$ \\
\hline \multirow[t]{5}{*}{ Latossolo } & Pastagem $\left(\mathrm{PL}_{1}\right)$ & 1 & $20^{\circ} 23^{\prime} 39,5^{\prime \prime}$ & $51^{\circ} 20^{\prime} 47,0^{\prime \prime}$ \\
\hline & & 2 & $20^{\circ} 23^{\prime} 31,5^{\prime \prime}$ & $51^{\circ} 20^{\prime} 37,8^{\prime \prime}$ \\
\hline & & 3 & $20^{\circ} 23^{\prime} 34,3^{\prime \prime}$ & $51^{\circ} 20^{\prime} 32,4^{\prime \prime}$ \\
\hline & & 4 & $20^{\circ} 23^{\prime} 36,9^{\prime \prime}$ & $51^{\circ} 20^{\prime} 24,4^{\prime \prime}$ \\
\hline & & 5 & $20^{\circ} 23^{\prime} 45,6^{\prime \prime}$ & $51^{\circ} 20^{\prime} 24,0^{\prime \prime}$ \\
\hline \multirow[t]{5}{*}{ Latossolo } & Pastagem $\left(\mathrm{PL}_{2}\right)$ & 1 & $20^{\circ} 24^{\prime} 46,4^{\prime \prime}$ & $51^{\circ} 20^{\prime} 37,3^{\prime \prime}$ \\
\hline & & 2 & $20^{\circ} 24^{\prime} 48,8^{\prime \prime}$ & $51^{\circ} 20^{\prime} 35,2^{\prime \prime}$ \\
\hline & & 3 & $20^{\circ} 24^{\prime} 51,1^{\prime \prime}$ & $51^{\circ} 20^{\prime} 32,1^{\prime \prime}$ \\
\hline & & 4 & $20^{\circ} 24^{\prime} 53,7^{\prime \prime}$ & $51^{\circ} 20^{\prime} 26,7^{\prime \prime}$ \\
\hline & & 5 & $20^{\circ} 24^{\prime} 51,9^{\prime \prime}$ & $51^{\circ} 20^{\prime} 22,3^{\prime \prime}$ \\
\hline \multirow[t]{5}{*}{ Latossolo-Argissolo } & Vegetação degradada & 1 & $20^{\circ} 23^{\prime} 46,5^{\prime \prime}$ & $51^{\circ} 21^{\prime} 03,4^{\prime \prime}$ \\
\hline & com pequenos fragmentos & 2 & $20^{\circ} 23^{\prime} 48,4^{\prime \prime}$ & $51^{\circ} 21^{\prime} 03,6^{\prime \prime}$ \\
\hline & remanescentes de área com & 3 & $20^{\circ} 23^{\prime} 45,3^{\prime \prime}$ & $51^{\circ} 21^{\prime} 04,3^{\prime \prime}$ \\
\hline & vegetação nativa (VD) & 4 & $20^{\circ} 24^{\prime} 05,3^{\prime \prime}$ & $51^{\circ} 21^{\prime} 11,8^{\prime \prime}$ \\
\hline & & 5 & $20^{\circ} 24^{\prime} 06,8^{\prime \prime}$ & $51^{\circ} 21^{\prime} 11,0^{\prime \prime}$ \\
\hline \multirow[t]{5}{*}{ Argissolo } & Pastagem $\left(\mathrm{P} \arg _{1}\right)$ & 1 & $20^{\circ} 23^{\prime} 32,2^{\prime \prime}$ & $51^{\circ} 20^{\prime} 56,1^{\prime \prime}$ \\
\hline & & 2 & $20^{\circ} 23^{\prime} 33^{\prime \prime}$ & $51^{\circ} 20^{\prime} 54,1^{\prime \prime}$ \\
\hline & & 3 & $20^{\circ} 23^{\prime} 34,1^{\prime \prime}$ & $51^{\circ} 20^{\prime} 54,3^{\prime \prime}$ \\
\hline & & 4 & $20^{\circ} 23^{\prime} 33,9^{\prime \prime}$ & $51^{\circ} 20^{\prime} 55,5^{\prime \prime}$ \\
\hline & & 5 & $20^{\circ} 23^{\prime} 33,1^{\prime \prime}$ & $51^{\circ} 20^{\prime} 56,5^{\prime \prime}$ \\
\hline \multirow[t]{5}{*}{ Argissolo } & Cultura Anual (CA arg) & 1 & $20^{\circ} 23^{\prime} 53,6^{\prime \prime}$ & $51^{\circ} 21^{\prime} 20,8^{\prime \prime}$ \\
\hline & & 2 & $20^{\circ} 23^{\prime} 46,9^{\prime \prime}$ & $51^{\circ} 21^{\prime} 23,5^{\prime \prime}$ \\
\hline & & 3 & $20^{\circ} 23^{\prime} 47,6^{\prime \prime}$ & $51^{\circ} 21^{\prime} 21,8^{\prime \prime}$ \\
\hline & & 4 & $20^{\circ} 23^{\prime} 44,0^{\prime \prime}$ & $51^{\circ} 21^{\prime} 24,2^{\prime \prime}$ \\
\hline & & 5 & $20^{\circ} 23^{\prime} 44,4^{\prime \prime}$ & $51^{\circ} 21^{\prime} 28,8^{\prime \prime}$ \\
\hline \multirow[t]{5}{*}{ Argissolo } & Pastagem $\left(\mathrm{P} \arg _{2}\right)$ & 1 & $20^{\circ} 24^{\prime} 08,9^{\prime \prime}$ & $51^{\circ} 20^{\prime} 16,3^{\prime \prime}$ \\
\hline & & 2 & $20^{\circ} 24^{\prime} 06,3^{\prime \prime}$ & $51^{\circ} 20^{\prime} 15,5^{\prime \prime}$ \\
\hline & & 3 & $20^{\circ} 24^{\prime} 03,4^{\prime \prime}$ & $51^{\circ} 20^{\prime} 11,7^{\prime \prime}$ \\
\hline & & 4 & $20^{\circ} 24^{\prime} 05,6^{\prime \prime}$ & $51^{\circ} 20^{\prime} 11,6^{\prime \prime}$ \\
\hline & & 5 & $20^{\circ} 24^{\prime} 03,2^{\prime \prime}$ & $51^{\circ} 20^{\prime} 18,2^{\prime \prime}$ \\
\hline
\end{tabular}


Na Tabela 3 encontram-se os valores médios dos teores de água nos solos durante a coleta de solo e avaliações de infiltração de água e de condutividade hidráulica para as camadas de 0 a 10 e de 10 a $20 \mathrm{~cm}$.

Tabela 3. Valores médios dos teores de água nos solos $\left(\mathrm{m}^{3} \mathrm{~m}^{-3}\right)$ durante a coleta de solo e avaliações de infiltração de água e de condutividade hidráulica, para as duas classes de solos, sob diferentes formas de uso e de ocupação, nas camadas de 0 a 10 e de 10 a $20 \mathrm{~cm}$.

\begin{tabular}{|c|c|c|}
\hline \multirow[b]{2}{*}{ Usos e ocupações dos solos } & \multicolumn{2}{|c|}{ Teores de água nos solos $\left(\mathrm{m}^{3} \mathrm{~m}^{-3}\right)$} \\
\hline & 0 a $10 \mathrm{~cm}$ & 10 a $20 \mathrm{~cm}$ \\
\hline \multicolumn{3}{|c|}{ Latossolo Vermelho distrófico } \\
\hline M & 0,15 & 0,16 \\
\hline $\mathrm{P}$ & 0,14 & 0,14 \\
\hline PA & 0,08 & 0,09 \\
\hline $\mathrm{PL}_{1}$ & 0,12 & 0,11 \\
\hline $\mathrm{PL}_{2}$ & 0,10 & 0,12 \\
\hline $\mathrm{CA}$ & 0,12 & 0,15 \\
\hline \multicolumn{3}{|c|}{ Argissolo Vermelho-Amarelo eutrófico } \\
\hline VD & 0,14 & 0,15 \\
\hline $\mathrm{P} \arg _{1}$ & 0,20 & 0,17 \\
\hline $\mathrm{CA}$ arg & 0,31 & 0,27 \\
\hline $\mathrm{P} \arg _{2}$ & 0,17 & 0,21 \\
\hline
\end{tabular}

Na Figura 7 estão apresentados os locais de coletas de solos dentro das duas classes de solos e de diferentes formas de uso e de ocupação presentes na Sub-bacia. Os usos e ocupações no Latossolo foram: cultura da manga (M) (Figura 7a), quatro locais com pastagem (P, PA, $\mathrm{PL}_{1}$ e $\mathrm{PL}_{2}$ ) (Figuras 7b, 7c, 7e, 7f, respectivamente), a cultura anual (CA) (Figura 7d) (solo preparado para a implantação da cultura do milho) e a vegetação arbórea degradada com pequenos fragmentos remanescentes de áreas com vegetação nativa (VD) (Figura 7g) que se encontra em uma área de transição entre o Latossolo e o Argissolo. No Argissolo os usos e ocupações foram: dois locais com pastagem ( $\mathrm{P} \arg _{1}$ e $\mathrm{P} \arg _{2}$ ) (Figuras $7 \mathrm{~h}$, 7j) e a cultura anual (CA arg) (Figura 7i) (solo preparado para a implantação da cultura do milho). 

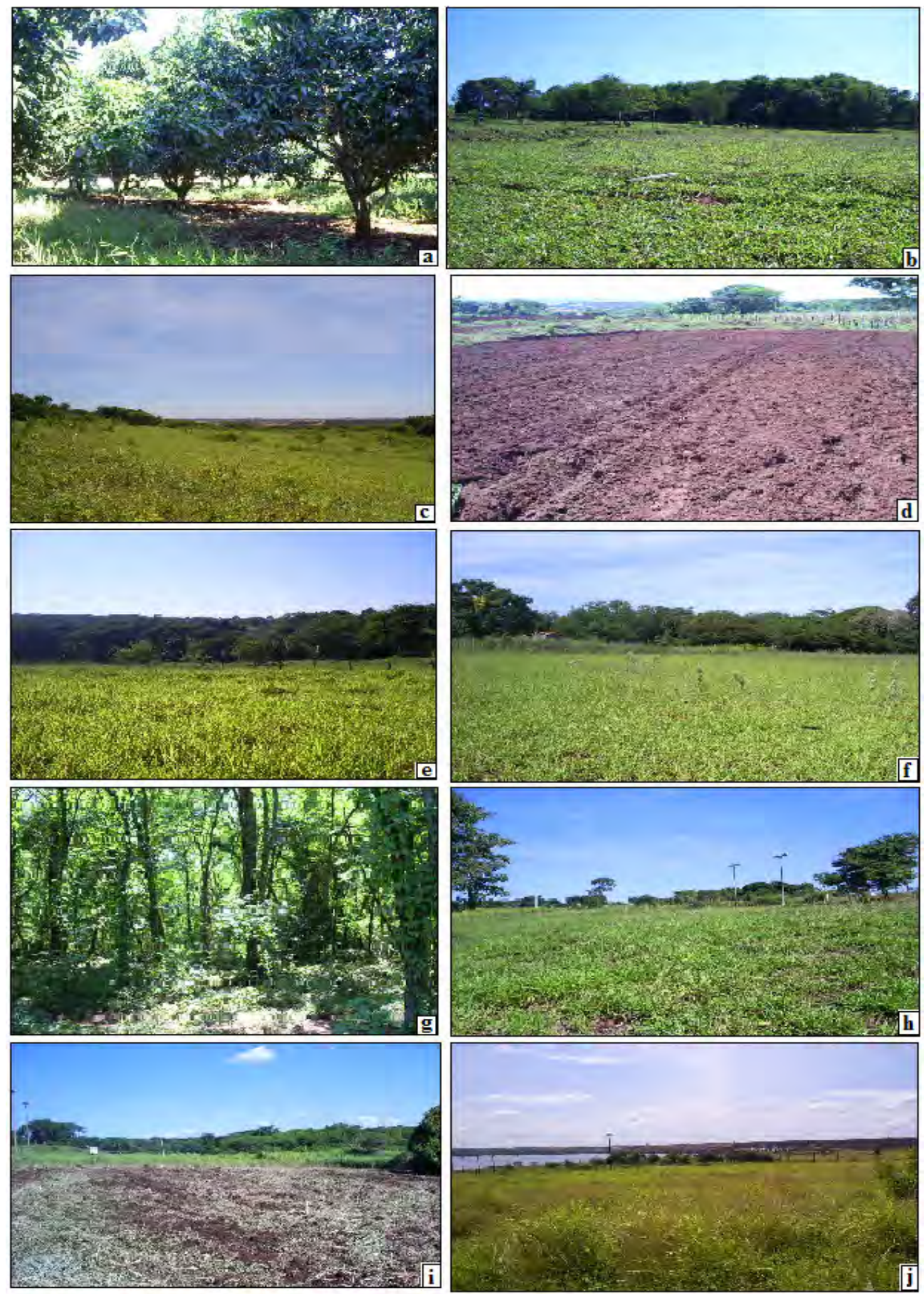

Figura 7. Locais de coletas de solos sob diferentes formas de uso e de ocupação. 


\subsection{Descrição dos usos e ocupações do solo}

a) Vegetação degradada: Área de vegetação arbórea com pequenos fragmentos remanescentes de áreas com vegetação nativa.

b) Cultura perene: Área que está sendo cultivada com a cultura da manga (Mangifera indica L.) há 12 anos.

c) Cultura anual: Área que vem sendo cultivada há 20 anos com milho (Zea mays L.) em preparo convencional (arado de discos e grade niveladora). A cultura do milho é cultivada somente no verão (período chuvoso), ficando a área em pousio durante o restante do ano.

d) Pastagem: Área com braquiária (Brachiaria decumbens Stapf) implantada há 08 anos.

\subsection{Avaliações}

\subsubsection{Textura do solo}

A textura do solo foi determinada pelo método da pipeta, segundo a metodologia descrita pela Embrapa (1997), com amostras deformadas, secas ao ar e passadas em peneiras de $2 \mathrm{~mm}$ de malha, submetidas a dispersão e sedimentação das partículas.

\subsubsection{Estabilidade de agregados em água}

Para a determinação da estabilidade de agregados em água foi utilizado o método descrito por Angers e Mehuys (2000), pelo qual, as amostras indeformadas foram secas ao ar e passadas em uma peneira de $6 \mathrm{~mm}$ de malha e os agregados retidos na peneira com $4 \mathrm{~mm}$ de abertura, para a determinação da estabilidade de agregados em água, utilizando peneiras com abertura de malha de $4 ; 2 ; 1 ; 0,5$ e $0,25 \mathrm{~mm}$ e agitação lenta por 10 minutos. Os resultados foram representados pelo diâmetro médio ponderado (DMP), que é o somatório dos produtos entre o diâmetro médio de cada fração de agregados e a proporção da massa da amostra, que é obtida pela divisão da massa de agregados retidos em cada peneira pela massa 
da amostra corrigida em termos de teor de água no solo. Também foram expressos em porcentagem das classes de agregados, sendo considerados os tamanhos: entre 6 e 4 ; 4 e 2; 2 e $1 ; 1$ e 0,$5 ; 0,5$ e 0,$25 ;$ e $<0,25$.

\subsubsection{Porosidade total, macroporosidade e microporosidade}

O método empregado para a determinação dessas características foi o do "anel volumétrico" para a porosidade total; o da "mesa de tensão", para a microporosidade, sendo as amostras indeformadas saturadas e colocadas sobre a mesa de tensão, onde foram submetidas a uma tensão de $6 \mathrm{kPa}$, e posteriormente pesadas e colocadas em estufa a $105^{\circ} \mathrm{C}$ até atingir peso constante; e a macroporosidade foi calculada por diferença entre a porosidade total e a microporosidade (EMBRAPA, 1997).

\subsubsection{Densidade do solo}

As mesmas amostras utilizadas para a determinação da porosidade do solo permitiram a determinação da densidade do solo, pelo método do "anel volumétrico" (EMBRAPA, 1997).

\subsubsection{Infiltração de água e condutividade hidráulica do solo saturado}

Para a determinação da infiltração de água e da condutividade hidráulica do solo saturado na superfície do solo foi utilizado o mini infiltrômetro de disco (Figura 8). O infiltrômetro foi colocado sobre o solo, sob uma camada de areia fina para garantir bom contato hidráulico entre o disco e o solo. As leituras foram realizadas de $30 \mathrm{em}$ 30 segundos, até obter infiltração constante, sendo o mini infiltrômetro ajustado para uma sucção $\mathrm{h}_{0}$ igual a $2 \mathrm{~cm}$. 


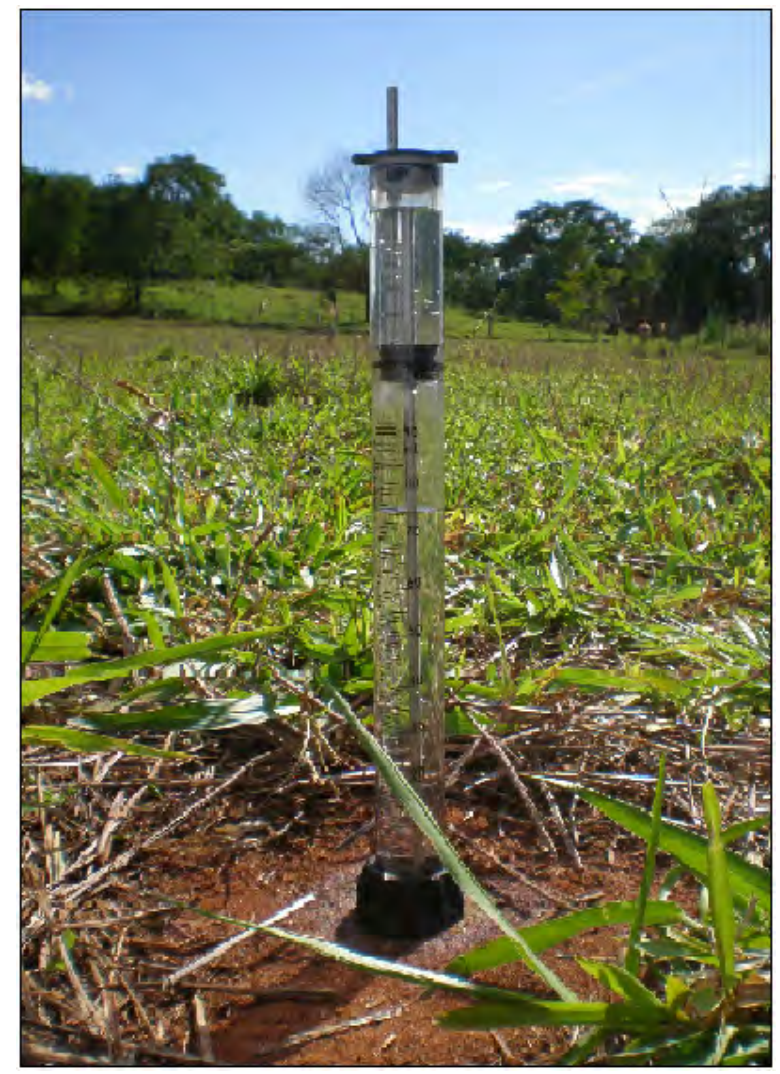

Figura 8. Mini infiltrômetro de disco.

O processo de infiltração a partir do infiltrômetro de disco, para qualquer tempo de infiltração, é descrito por um modelo proposto por Zhang (1997):

$$
I=C_{1} t+C_{2} \sqrt{t}
$$

Onde, $\mathrm{C}_{1}\left(\mathrm{~cm} \mathrm{~s}^{-1}\right)$ e $\mathrm{C}_{2}\left(\mathrm{~cm} \mathrm{~s}^{-0,5}\right)$ são parâmetros relacionados à condutividade hidráulica $\mathrm{K}\left(\mathrm{h}_{0}\right)$ do solo e à sorvidade $\mathrm{S}\left(\mathrm{h}_{0}\right)$, e I é a infiltração acumulada $(\mathrm{cm})$.

A condutividade hidráulica foi determinada a partir de dados de infiltração acumulada, utilizando-se a relação dada por:

$$
\mathrm{k}=\frac{\mathrm{C}_{1}}{\mathrm{~A}}
$$

Onde $\mathrm{C}_{1}$ é a constante obtida no gráfico de infiltração acumulada, e A é um valor relacionado a um parâmetro de Van Genuchten (1980) (Apêndice 1), para 
determinado tipo de solo e de sucção utilizada no infiltrômetro de disco durante o processo de infiltração.

Nas profundidades de 10 e $20 \mathrm{~cm}$ foi utilizado o permeâmetro de Guelph (Figura 9) para as medições de infiltração de água e de condutividade hidráulica do solo saturado, sendo realizadas leituras de 1 em 1 minuto até se obter infiltração constante. Mediu-se a taxa constante de infiltração e calculou-se a condutividade hidráulica do solo saturado segundo Reynolds e Elrick (1985).

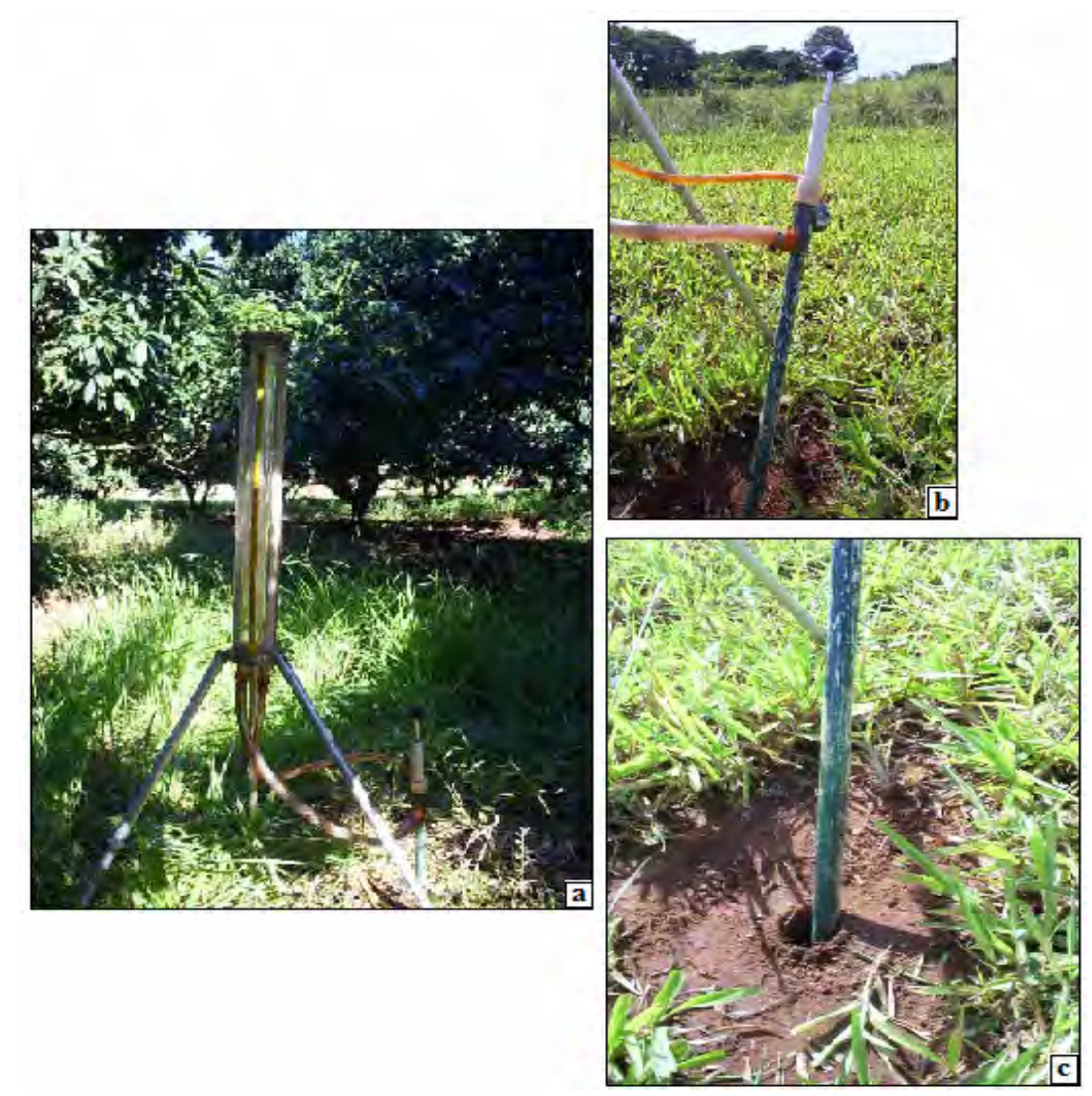

Figura 9. Permeâmetro de Guelph (a), detalhe da carga hidráulica (b) e orifício (c).

As avaliações foram feitas empregando-se duas cargas hidráulicas, de 3 e $6 \mathrm{~cm}$, e após realizadas as medições, os dados foram analisados segundo modelos matemáticos propostos por Vieira et al. (1988) de acordo com a seguinte equação:

$$
\mathrm{Q}=\left\{\left(\frac{2 \pi \mathrm{H}^{2}}{\mathrm{C}}\right)+\pi \mathrm{a}^{2}\right\} \mathrm{k}_{\mathrm{fi}}+\left(\frac{2 \pi \mathrm{H}}{\mathrm{C}}\right)+\psi_{\mathrm{m}}
$$


Onde:

$\mathrm{Q}=$ Fluxo constante, $\mathrm{cm}^{3} \mathrm{~cm}^{-3}$;

$\mathrm{H}=$ Carga hidráulica utilizada, $\mathrm{cm}$;

$\mathrm{C}=$ Fator de geometria, $\mathrm{cm} \mathrm{cm}^{-1}$;

$\mathrm{a}=$ Raio do orifício onde as medições foram feitas, $\mathrm{cm}$;

$\mathrm{K}_{\mathrm{fs}}=$ Condutividade hidráulica do solo saturado, $\mathrm{cm} \mathrm{s}^{-1}$;

$\Psi_{\mathrm{m}}=$ Potencial matricial do fluxo, $\mathrm{cm}^{2} \mathrm{~s}^{-1}$.

Os resultados para a infiltração de água e para a condutividade hidráulica do solo saturado foram classificados de acordo com Soil Survey Staff (1993) (Apêndice 2).

\subsubsection{Variação de armazenamento de água no solo}

Para a determinação da variação de armazenamento de água no solo, as amostras indeformadas foram colocadas no aparelho extrator de Richards segundo metodologia da Embrapa (1997).

As amostras foram submetidas às tensões de -10 e -300 kPa, obtendose assim o teor de água no solo sob essas duas tensões, para posterior cálculo da variação de armazenamento de água no solo, por meio da fórmula:

$$
\Delta \mathrm{A}=\left(\theta_{\mathrm{cc}}-\theta_{-300 \mathrm{kPa}}\right) \cdot \mathrm{z}
$$

Onde:

$\Delta \mathrm{A}=$ Variação de armazenamento de água no solo, $\mathrm{mm}$;

$\Theta_{c c}=$ Teor de água no solo com base em volume na capacidade de campo $(-10 \mathrm{kPa})$;

$\Theta_{-300 \mathrm{kPa}}=$ Teor de água no solo com base em volume na tensão de -300 $\mathrm{kPa}$;

$\mathrm{z}=$ Camada onde foi coletada a amostra, $\mathrm{mm}$. 


\subsubsection{Fertilidade do solo}

$\mathrm{Na}$ análise química dos solos foram determinados os teores disponíveis de Fósforo e de bases trocáveis. Determinou-se também o teor de matéria orgânica, pH, Alumínio, $\mathrm{H}+\mathrm{Al}$ e micronutrientes. Foram calculadas a Soma de Bases, CTC e V\% (RAIJ et al., 2001).

\subsection{Escoamento superficial}

A simulação do escoamento superficial foi realizada usando-se o programa SIMHUNER (DÍAZ et al., 2007). Para a simulação foram empregados dados diários de precipitação, de evapotranspiração e de vazão, no período de agosto de 1991 a agosto de 2009. Os dados de precipitação e de evapotranspiração do município de Ilha Solteira, SP, foram obtidos do "site" do Departamento de Hidráulica e Irrigação (FE/IS/UNESP, 2009).

A vazão foi estimada utilizando-se a equação proposta por Soil Conservation Service-SCS (USDA-SCS, 1972):

$$
Q=\left(\frac{R-0,25}{R+0,85}\right)^{2}
$$

Onde:

$\mathrm{Q}=$ escoamento superficial diário, $\mathrm{mm}$;

$\mathrm{R}=$ precipitação diária, $\mathrm{mm}$;

$\mathrm{S}=$ parâmetro de retenção, $\mathrm{mm}$.

O parâmetro de retenção varia de acordo com a bacia, em função do solo, do uso do solo, da declividade e também com o tempo, devido às alterações ocorridas e com o teor de água no solo. Este parâmetro está relacionado com a curva número (CN) pela seguinte equação:

$$
\mathrm{S}=\frac{25.400}{\mathrm{CN}}-254
$$


Em que $\mathrm{CN}$ é o número da curva, cujo valor pode variar entre 1 e 100 (Apêndice 3), e depende do uso e do manejo do solo, do grupo de solo, da condição hidrológica e do teor de água antecedente no solo.

Quando a precipitação acumulada dos últimos cinco dias for menor que $36 \mathrm{~mm}$ ou quando o teor de água no solo estiver abaixo da capacidade de campo, os valores de $\mathrm{CN}$ devem ser corrigidos de acordo com a seguinte expressão:

$$
C N_{f}=\frac{4,2 \mathrm{CN}_{\mathrm{II}}}{10-0,058 \mathrm{CN}_{11}}
$$

Em que $\mathrm{CN}_{\mathrm{I}}$ é o número da curva corrigido para as condições de teor de água I, e $\mathrm{CN}_{\mathrm{II}}$ é o número da curva obtido para a Sub-bacia em estudo.

Quando a precipitação antecedente dos últimos cinco dias for superior a $53 \mathrm{~mm}$ ou quando o solo estiver com teor de água acima da capacidade de campo, o valor de $\mathrm{CN}$ deve ser corrigido por:

$$
C N_{n}=\frac{23 \mathrm{CN}_{\mathrm{II}}}{10+0,13 \mathrm{CN}_{11}}
$$

Em que $\mathrm{CN}_{\text {III }}$ é o número da curva corrigido para as condições de teor de água III.

O método ainda assume para o cálculo do $\mathrm{CN}$ os seguintes tipos de solo (TUCCI, 2001):

- Solo A - Baixo potencial de escoamento, alta taxa de infiltração quando completamente úmido e perfil profundo, geralmente arenoso com pouco silte e pouca argila.

- Solo B - Moderada taxa de infiltração quando completamente úmido e profundidade moderada.

- Solo C - Baixa taxa de infiltração quando completamente úmido, camada de impedimento e considerável porcentagem de argila.

- Solo D - Elevado potencial de escoamento e baixa taxa de infiltração, raso e de camada impermeável. 


\subsection{Análise dos resultados}

Os resultados das propriedades físicas, químicas e relacionados à dinâmica da água nos solos foram submetidos à análise conjunta e teste estatístico de Tukey para as comparações de média a $5 \%$ de probabilidade. A análise foi realizada para cada classe de solo, sendo utilizado para a realização destas análises o programa computacional SAS (SCHLOTZHAVER e LITTELL, 1997). Para diminuir a amplitude das variâncias e do coeficiente de variação, foi realizada transformação raiz quadrada dos dados de classe de agregados, macroporosidade, infiltração, condutividade hidráulica e análise química. 


\section{RESULTADOS E DISCUSSÃO}

\subsection{Propriedades físicas e químicas dos solos}

Na Tabela 4 estão contidos os valores médios da porcentagem de cada classe de agregados para os diferentes usos e ocupações nas duas classes de solos, nas camadas de 0 a 10 e de 10 a $20 \mathrm{~cm}$.

Os valores de porcentagem de agregados para a camada de 0 a $10 \mathrm{~cm}$ variaram de 25,49 a 83,87\% no Latossolo e de 18,26 a 49,16\% no Argissolo para a classe entre 6 e $4 \mathrm{~mm}$, os maiores valores encontrados para esta classe de agregados, nas duas classes de solo, foram para as pastagens. Para a classe entre 4 e $2 \mathrm{~mm}$, os valores variaram de 7,66 a 20,59\% no Latossolo e de 12,69 a 25,19\% no Argissolo, sendo observado o maior valor para a cultura da manga (M) e para a pastagem $\left(\mathrm{P} \arg _{2}\right)$, respectivamente. Os valores para a classe entre 2 e $1 \mathrm{~mm}$ variaram de 0,81 a 7,32\% no Latossolo, observando-se o maior valor para a cultura da manga (M), e de 5,38 a 23,81\% no Argissolo, sendo verificado o maior valor para a cultura anual (CA arg). Na classe de agregados entre 1 e $0,5 \mathrm{~mm}$ os valores variaram de 0,78 a $12,55 \%$ no Latossolo e de 4,51 a 17,56\% no Argissolo, sendo os maiores valores observados para as culturas anuais nas duas classes de solos. Para a classe entre 0,5 e 0,25 mm os valores estavam entre 1,05 a 12,74\% no Latossolo e 4,39 a 10,63\% no Argissolo, sendo o maior valor observado para a cultura anual (CA) e para a vegetação degradada (VD), respectivamente. 
Tabela 4. Valores médios da porcentagem de agregados estáveis em água (\%), para as seis classes de tamanhos de agregados, nas duas classes de solos, sob diferentes formas de uso e de ocupação, nas camadas de 0 a 10 e 10 a 20 cm.

\begin{tabular}{|c|c|c|c|c|c|c|}
\hline \multirow{2}{*}{$\begin{array}{c}\text { Usos e ocupações } \\
\text { dos solos }\end{array}$} & \multicolumn{6}{|c|}{ Classes de agregados $(\mathrm{mm})$} \\
\hline & 6 e 4 mm & 4 e 2 mm & 2 e $1 \mathrm{~mm}$ & 1 e $0,5 \mathrm{~mm}$ & 0,5 e 0,25 mm & $<0,25 \mathrm{~mm}$ \\
\hline \multicolumn{7}{|c|}{ Camada 0 a $10 \mathrm{~cm}$} \\
\hline \multicolumn{7}{|c|}{------------------------- $\%$------------------------- } \\
\hline \multicolumn{7}{|c|}{ Latossolo Vermelho distrófico } \\
\hline M & $32,35 \quad \mathrm{BC}$ & $20,59 \mathrm{~A}$ & $7,32 \mathrm{~A}^{*}$ & $9,87 \mathrm{AB}^{*}$ & $9,03 \mathrm{AB}^{*}$ & $20,84 \mathrm{AB}^{*}$ \\
\hline $\mathrm{P}$ & $64,64 \mathrm{AB}$ & $14,70 \mathrm{AB}$ & $3,71 \mathrm{AB}^{*}$ & $3,32 \mathrm{BC}^{*}$ & $2,41 \quad C^{*}$ & $11,22 \mathrm{BC}^{*}$ \\
\hline PA & $63,00 \mathrm{AB}$ & $16,21 \mathrm{AB}$ & $1,91 \mathrm{~B} *$ & 1,46 & 2,26 & $15,17 \mathrm{ABC}^{*}$ \\
\hline $\mathrm{PL}_{1}$ & $60,06 \mathrm{AB}$ & $17,17 \mathrm{AB}$ & $3,62 \mathrm{AB} *$ & $3,96 \mathrm{ABC}^{*}$ & $3,75 \mathrm{BC} *$ & $11,45 \mathrm{BC}^{*}$ \\
\hline $\mathrm{PL}_{2}$ & $83,87 \mathrm{~A}$ & $7,66 \mathrm{~B}$ & $0,81 \quad \mathrm{~B} *$ & $0,78 \quad \mathrm{C}^{*}$ & 1,05 & 5,84 \\
\hline $\mathrm{CA}$ & $25,49 \quad \mathrm{C}$ & $13,60 \mathrm{AB}$ & $7,04 \mathrm{~A}^{*}$ & $12,55 \mathrm{~A}^{*}$ & $12,74 \mathrm{~A}^{*}$ & $28,58 \mathrm{~A}^{*}$ \\
\hline $\mathrm{CV}(\%)$ & 30,18 & 36,06 & 30,24 & 42,95 & 38,13 & 26,20 \\
\hline \multicolumn{7}{|c|}{ Argissolo Vermelho-Amarelo eutrófico } \\
\hline VD & $31,82 \mathrm{~A}^{*}$ & $14,15 \quad \mathrm{BC}$ & $7,50 \quad \mathrm{~B} *$ & $9,12 \mathrm{AB}^{*}$ & $10,63 \mathrm{~A}^{*}$ & $26,78 \mathrm{~A}^{*}$ \\
\hline $\mathrm{P} \arg _{1}$ & $49,16 \mathrm{~A}^{*}$ & 12,69 & $7,19 \mathrm{~B}^{*}$ & $8,81 \mathrm{AB}^{*}$ & $7,66 \mathrm{~A}^{*}$ & $14,49 \mathrm{~A}^{*}$ \\
\hline CA $\arg$ & $18,26 \mathrm{~A}^{*}$ & $20,34 \mathrm{AB}$ & $23,81 \mathrm{~A}^{*}$ & $17,56 \mathrm{~A}^{*}$ & $8,26 \mathrm{~A}^{*}$ & $11,77 \mathrm{~A}^{*}$ \\
\hline $\mathrm{P} \arg _{2}$ & $46,33 \mathrm{~A}^{*}$ & $25,19 \mathrm{~A}$ & $5,38 \quad \mathrm{~B} *$ & $4,51 \quad \mathrm{~B}^{*}$ & $4,39 \mathrm{~A}^{*}$ & $14,20 \mathrm{~A}^{*}$ \\
\hline $\mathrm{CV}(\%)$ & 37,40 & 21,55 & 33,05 & 38,60 & 37,56 & 32,59 \\
\hline \multicolumn{7}{|c|}{ Camada 10 a $20 \mathrm{~cm}$} \\
\hline & & ---- & --------------- & \% - - - ----- & -------- & \\
\hline \multicolumn{7}{|c|}{ Latossolo Vermelho distrófico } \\
\hline M & $23,38 \quad \mathrm{BC}^{*}$ & $20,91 \mathrm{~A}$ & $9,72 \mathrm{AB}$ & $12,60 \mathrm{AB}^{*}$ & $12,36 \mathrm{AB}^{*}$ & $21,03 \mathrm{AB}^{*}$ \\
\hline $\mathrm{P}$ & $51,82 \mathrm{AB}^{*}$ & $14,03 \mathrm{AB}$ & $6,17 \mathrm{ABC}$ & $7,71 \quad \mathrm{BC}^{*}$ & $7,11 \quad \mathrm{BC}^{*}$ & $13,16 \mathrm{AB}^{*}$ \\
\hline PA & $37,31 \mathrm{ABC}^{*}$ & $16,79 \mathrm{AB}$ & $5,36 \mathrm{ABC}$ & $6,41 \quad \mathrm{BC}^{*}$ & $7,89 \quad \mathrm{BC}^{*}$ & $26,24 \mathrm{AB}^{*}$ \\
\hline $\mathrm{PL}_{1}$ & $71,50 \mathrm{~A}^{*}$ & $9,15 \quad \mathrm{~B}$ & 2,27 & 2,48 & 2,86 & $11,74 \mathrm{~B}^{*}$ \\
\hline $\mathrm{PL}_{2}$ & $61,72 \mathrm{AB}^{*}$ & $11,74 \mathrm{~B}$ & $4,25 \mathrm{BC}$ & 4,66 & $4,54 \mathrm{BC} *$ & $13,09 \mathrm{AB}^{*}$ \\
\hline $\mathrm{CA}$ & $13,81 \quad \mathrm{C}^{*}$ & $9,84 \quad \mathrm{~B}$ & $10,22 \mathrm{~A}$ & $18,65 \mathrm{~A}^{*}$ & $16,04 \mathrm{~A}^{*}$ & $31,44 \mathrm{~A}^{*}$ \\
\hline $\mathrm{CV}(\%)$ & 25,91 & 32,78 & 44,58 & 37,67 & 26,22 & 26,42 \\
\hline \multicolumn{7}{|c|}{ Argissolo Vermelho-Amarelo eutrófico } \\
\hline VD & $18,78 \mathrm{~A}^{*}$ & $10,30 \mathrm{~A}$ & $9,20 \quad \mathrm{~B}$ & $12,83 \mathrm{~A}^{*}$ & $14,64 \mathrm{~A}^{*}$ & $34,24 \mathrm{~A}^{*}$ \\
\hline $\mathrm{P} \arg _{1}$ & $41,88 \mathrm{~A}^{*}$ & $12,32 \mathrm{~A}$ & $7,85 \quad \mathrm{~B}$ & $11,65 \mathrm{~A}^{*}$ & $9,74 \mathrm{~A}^{*}$ & $16,55 \mathrm{~B} *$ \\
\hline CA arg & $16,53 \mathrm{~A}^{*}$ & $17,96 \mathrm{~A}$ & $25,51 \mathrm{~A}$ & $22,82 \mathrm{~A}^{*}$ & $7,50 \mathrm{~A}^{*}$ & $9,68 \mathrm{~B} *$ \\
\hline $\mathrm{P} \arg _{2}$ & $51,21 \mathrm{~A}^{*}$ & $15,53 \mathrm{~A}$ & $7,20 \quad \mathrm{~B}$ & $6,97 \mathrm{~A}^{*}$ & $5,21 \mathrm{~A} *$ & $13,87 \mathrm{~B} *$ \\
\hline $\mathrm{CV}(\%)$ & 45,18 & 34,64 & 44,22 & 36,28 & 32,39 & 22,51 \\
\hline
\end{tabular}

Médias seguidas de mesma letra, na coluna, não diferem estatisticamente entre si pelo teste de Tukey a 5\% de probabilidade.

* As letras são referentes à comparação dos dados transformados para raiz quadrada.

$\mathrm{M}=$ Cultura da manga, $\mathrm{P}=$ Pastagem, $\mathrm{PA}=$ Pastagem, $\mathrm{PL}_{1}=$ Pastagem, $\mathrm{PL}_{2}=$ Pastagem, $\mathrm{CA}=$ cultura anual, $\mathrm{VD}$

= Vegetação degradada com pequenos fragmentos de área com vegetação nativa, $\mathrm{P} \arg _{1}=\mathrm{Pastagem}_{\mathrm{CA}} \mathrm{Crg}=$

Cultura anual e $\mathrm{P} \arg _{2}=$ Pastagem. 
Na classe menor a $0,25 \mathrm{~mm}$ os valores variaram de 5,83 a $28,58 \%$ no Latossolo, verificando o maior valor para a cultura anual (CA), e de 11,77 a $26,78 \%$ no Argissolo, observando para a vegetação degradada (VD) o maior valor.

Para a camada de 10 a $20 \mathrm{~cm}$, no Latossolo os valores de porcentagem de agregados variaram de 13,81 a 71,50\% para a classe entre 6 e $4 \mathrm{~mm}$, de 9,15 a 20,91\% para a classe entre 4 e $2 \mathrm{~mm}$, de 2,27 a 10,22\% para a classe entre 2 e $1 \mathrm{~mm}$, de 2,48 a 18,65\% para a classe entre 1 e $0,5 \mathrm{~mm}$, de 2,86 a 16,04\% para a classe entre 0,5 e 0,25 mm e de 11,74 a 31,44 para a classe menor a $0,25 \mathrm{~mm}$. No Argissolo estes valores variaram de 16,53 a 51,21\% para a classe entre 6 e $4 \mathrm{~mm}$, de 10,30 a 17,96\% para a classe entre 4 e $2 \mathrm{~mm}$, de 7,20 a $25,51 \%$ para a classe entre 2 e $1 \mathrm{~mm}$, de 6,97 a 22,82\% para a classe entre 1 e $0,5 \mathrm{~mm}$, de 5,21 a $14,64 \%$ para a classe entre 0,5 e $0,25 \mathrm{~mm}$, e de 9,68 a $34,25 \%$ para a classe menor a 0,25 $\mathrm{mm}$.

A estabilidade de agregados é influenciada pelo uso e pelo manejo do solo. Quanto maior for o agregado, maior será a sua estabilidade em água. Solos com maior porcentagem de agregados estáveis em água podem ser considerados mais resistentes aos processos de erosão e de escoamento superficial.

Para a maior classe de agregados, entre 6 e $4 \mathrm{~mm}$, foi observado que os maiores valores encontrados foram para as pastagens em ambas as camadas estudadas e nas duas classes de solos, indicando que os agregados formados são bastante estáveis em água para este tipo de uso e ocupação do solo. Silva e Mielniczuk (1998) e Salton et al. (2008) também encontraram resultados semelhantes. De acordo com Salton et al. (2008) há um efeito do sistema radicular da pastagem permanente no processo de formação dos macroagregados.

Já para as culturas anuais, nas duas classes de solo, houve predominância de classes de agregados menores, devido ao uso intensivo do solo causado pelas culturas anuais, estes resultados concordam com os encontrados por Salton et al. (2008). Nestas classes de agregados menores, foi observado que no Latossolo a cultura anual (CA) não diferiu da cultura da manga (M), e no Argissolo a cultura anual não diferiu da vegetação degradada (VD). Apesar disso, tanto a cultura da manga (M) como a vegetação degradada (VD) apresentaram maiores porcentagens de agregados na classe de agregados entre 6 e $4 \mathrm{~mm}$.

Na Tabela 5 estão contidos os valores médios de diâmetro médio ponderado (DMP) dos agregados estáveis em água para as camadas de 0 a 10 e 10 a $20 \mathrm{~cm}$. 
Verificou-se que houve diferença significativa para os diferentes usos e ocupações do solo nas duas camadas estudadas para o Latossolo, já para o Argissolo não houve diferença significativa.

Tabela 5. Valores médios de diâmetro médio ponderado (DMP) de agregados estáveis em água $(\mathrm{mm})$, para as duas classes de solos, sob diferentes formas de uso e de ocupação, nas camadas de 0 a 10 e 10 a $20 \mathrm{~cm}$.

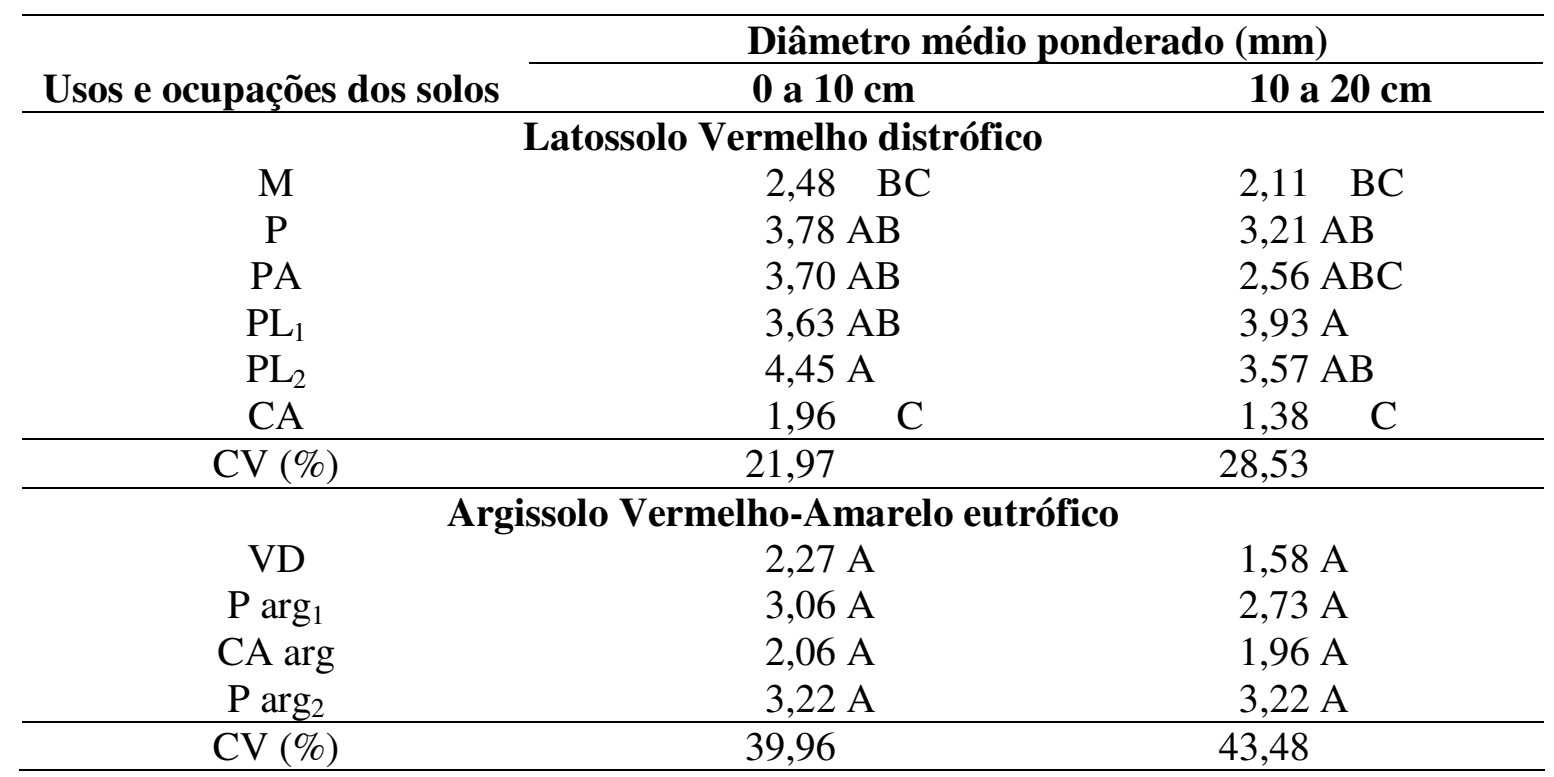

Médias seguidas de mesma letra, na coluna, não diferem estatisticamente entre si pelo teste de Tukey a 5\% de probabilidade.

$\mathrm{M}=$ Cultura da manga, $\mathrm{P}=$ Pastagem, $\mathrm{PA}=$ Pastagem, $\mathrm{PL}_{1}=$ Pastagem, $\mathrm{PL}_{2}=$ Pastagem, $\mathrm{CA}=$ cultura anual, $\mathrm{VD}$ = Vegetação degradada com pequenos fragmentos de área com vegetação nativa, $\mathrm{P} \arg _{1}=\mathrm{Pastagem}_{\mathrm{CA}} \mathrm{Carg}=$ Cultura anual e $\mathrm{P} \arg _{2}=$ Pastagem.

Os valores de DMP para a camada de 0 a $10 \mathrm{~cm}$ variaram de 1,96 a 4,45 mm no Latossolo e de 2,06 a 3,22 mm no Argissolo. Para a camada de 10 a $20 \mathrm{~cm}$ variaram de 1,38 a 3,93 mm no Latossolo e de 1,58 a 3,22 mm no Argissolo. Observa-se que os maiores valores se encontram na camada superficial do solo para as duas classes de solos, e que estes foram influenciados pelos diferentes usos e manejos dos solos.

Para a camada de 0 a $10 \mathrm{~cm}$ o maior valor encontrado no Latossolo foi para a pastagem $\left(\mathrm{PL}_{2}\right)$ com $4,45 \mathrm{~mm}$, e o menor valor foi atribuído para a cultura anual (CA) com 1,96 mm. No Argissolo ocorreu o mesmo, com maior valor para a pastagem $\left(\mathrm{P} \arg _{2}\right)$ com 3,22 mm, e menor para a cultura anual (CA arg) com 2,06 mm. Estes resultados concordam 
com os obtidos por Salton et al. (2008), os quais encontraram maior DMP para as pastagens e menor para a cultura anual.

Maiores valores de porcentagem de agregados nas classes entre 6 e 4 mm e 4 e $2 \mathrm{~mm}$ produzem maior valor de DMP, o qual foi observado para a as pastagens nas duas classes de solos, que apresentaram maiores valores de DMP devido à maior porcentagem de agregados na classe entre 6 e $4 \mathrm{~mm}$. O contrário foi observado para as culturas anuais que apresentaram os menores valores de DMP, devido à maior porcentagem de agregados nas classes de menor tamanho, e esta relação também é verificada para os demais usos.

Os maiores valores de DMP foram encontrados para as pastagens independentemente da classe de solo. De acordo com Marchão (2007), a estabilidade de agregados pode aumentar rapidamente com a inclusão de pastagens devido à ausência de preparo durante o ciclo da pastagem e a presença de um denso sistema radicular, que atua como agente agregante.

Quanto aos valores observados para o solo cultivado com a cultura da manga (M) no Latossolo com 2,48 mm, e sob vegetação degradada (VD) no Argissolo com $2,27 \mathrm{~mm}$, foram devido à maior porcentagem de agregados na classe entre 6 e $4 \mathrm{~mm}$, isto ocorreu provavelmente, por causa da maior cobertura do solo, com relação às culturas anuais. A deposição superficial de folhas secas que ficam em contato com o solo ocasiona maior cobertura e maior teor de matéria orgânica, além disso, a ausência do revolvimento do solo nestes dois sistemas de uso.

Os menores valores observados para as culturas anuais no Latossolo (CA) com 1,96 mm, e no Argissolo (CA arg) com 2,06 mm foram devido ao maior revolvimento do solo. Segundo Figueiredo et al. (2008), o plantio convencional consiste no uso excessivo de arados e grades no preparo do solo, especialmente a grade aradora, que diminui a estabilidade dos agregados, causando sua desestruturação.

Na camada de 10 a $20 \mathrm{~cm}$ observa-se que os maiores valores de DMP no Latossolo foram encontrados para a pastagem $\left(\mathrm{PL}_{1}\right)$ com 3,93 mm, e os menores valores para cultura anual (CA) com 1,38 mm. No Argissolo os maiores valores de DMP foram observados para a pastagem $\left(\mathrm{P} \arg _{2}\right) \operatorname{com} 3,22 \mathrm{~mm}$, e os menores valores para a vegetação degradada (VD) com 1,58 mm, seguido da cultura anual (CA arg) com 1,96 mm. Verificando também a mesma tendência da camada superficial, na qual as pastagens apresentaram os 
maiores valores de DMP e as culturas anuais os menores. Com exceção as pastagens $\left(\mathrm{PL}_{1}\right)$ no Latossolo e ( $\left.\mathrm{P} \arg _{2}\right)$ no Argissolo, observa-se para os demais usos nas duas classes de solos que o DMP diminui com o aumento da profundidade, devido à influência da cobertura do solo.

Quanto aos resultados da análise granulométrica dos solos, nas camadas de 0 a 10 e 10 a $20 \mathrm{~cm}$, estes se encontram na Tabela 6.

Tabela 6. Valores médios dos conteúdos de argila, de areia e de silte para as duas classes de solos, sob diferentes formas de uso e de ocupação, nas camadas de 0 a 10 e 10 a 20 $\mathrm{cm}$.

\begin{tabular}{|c|c|c|c|c|}
\hline \multirow{2}{*}{$\begin{array}{c}\text { Usos e ocupações } \\
\text { dos solos }\end{array}$} & $\operatorname{Argila}\left(\mathrm{g} \mathrm{kg}^{-1}\right)$ & Areia $\left(\mathrm{g} \mathrm{kg}^{-1}\right)$ & Silte $\left(\mathrm{g} \mathrm{kg}^{-1}\right)$ & \multirow[t]{2}{*}{ Classes texturais } \\
\hline & \multicolumn{3}{|c|}{ Camada 0 a $10 \mathrm{~cm}$} & \\
\hline \multicolumn{5}{|c|}{ Latossolo Vermelho distrófico } \\
\hline M & 208 & 684 & 108 & Franco-argilo-arenosa \\
\hline $\mathrm{P}$ & 195 & 710 & 95 & Franco-arenosa \\
\hline PA & 60 & 873 & 67 & Areia franca \\
\hline $\mathrm{PL}_{1}$ & 183 & 670 & 147 & Franco-arenosa \\
\hline $\mathrm{PL}_{2}$ & 167 & 732 & 101 & Franco-arenosa \\
\hline $\mathrm{CA}$ & 125 & 791 & 84 & Franco-arenosa \\
\hline \multicolumn{5}{|c|}{ Argissolo Vermelho-Amarelo eutrófico } \\
\hline VD & 249 & 554 & 197 & Franco-argilo-arenosa \\
\hline $\mathrm{P} \arg _{1}$ & 235 & 592 & 173 & Franco-argilo-arenosa \\
\hline CA arg & 339 & 186 & 475 & Franco-argilo-siltosa \\
\hline $\mathrm{P} \arg _{2}$ & 172 & 701 & 127 & Franco-arenosa \\
\hline \multicolumn{5}{|c|}{ Camada 10 a $20 \mathrm{~cm}$} \\
\hline \multicolumn{5}{|c|}{ Latossolo Vermelho distrófico } \\
\hline M & 284 & 623 & 93 & Franco-argilo-arenosa \\
\hline $\mathrm{P}$ & 238 & 666 & 96 & Franco-arenosa \\
\hline PA & 89 & 838 & 73 & Areia franca \\
\hline $\mathrm{PL}_{1}$ & 259 & 598 & 143 & Franco-argilo-arenosa \\
\hline $\mathrm{PL}_{2}$ & 220 & 649 & 131 & Franco-argilo-arenosa \\
\hline $\mathrm{CA}$ & 148 & 772 & 80 & Franco-arenosa \\
\hline \multicolumn{5}{|c|}{ Argissolo Vermelho-Amarelo eutrófico } \\
\hline VD & 277 & 520 & 203 & Franco-argilo-arenosa \\
\hline $\mathrm{P} \arg _{1}$ & 245 & 583 & 172 & Franco-argilo-arenosa \\
\hline $\mathrm{CA}$ arg & 362 & 178 & 460 & Franco-argilo-siltosa \\
\hline $\mathrm{P} \arg _{2}$ & 238 & 613 & 149 & Franco-argilo-arenosa \\
\hline
\end{tabular}


Os resultados obtidos para os conteúdos de argila variaram de 60 a 208 $\mathrm{g} \mathrm{kg}^{-1}$ no Latossolo e de 172 a $339 \mathrm{~g} \mathrm{~kg}^{-1}$ no Argissolo para a camada de 0 a $10 \mathrm{~cm}$, e de 89 a $284 \mathrm{~g} \mathrm{~kg}^{-1}$ no Latossolo e de 238 a $362 \mathrm{~g} \mathrm{~kg}^{-1}$ no Argissolo para a camada de 10 a $20 \mathrm{~cm}$. Os conteúdos de areia variaram de 670 a $873 \mathrm{~g} \mathrm{~kg}^{-1}$ no Latossolo e de 186 a $701 \mathrm{~g} \mathrm{~kg}^{-1}$ no Argissolo para a camada de 0 a $10 \mathrm{~cm}$, e de 598 a $838 \mathrm{~g} \mathrm{~kg}^{-1}$ no Latossolo e de 178 a $613 \mathrm{~g} \mathrm{~kg}^{-}$ ${ }^{1}$ no Argissolo para a camada de 10 a $20 \mathrm{~cm}$. E os conteúdos de silte variaram de 67 a $147 \mathrm{~g}$ $\mathrm{kg}^{-1}$ no Latossolo e de 127 a $475 \mathrm{~g} \mathrm{~kg}^{-1}$ no Argissolo para a camada de 0 a $10 \mathrm{~cm}$, e de 73 a $143 \mathrm{~g} \mathrm{~kg}^{-1}$ no Latossolo e de 149 a $460 \mathrm{~g} \mathrm{~kg}^{-1}$ no Argissolo para a camada de 10 a $20 \mathrm{~cm}$. Pode-se observar para as duas classes de solos que, no geral, estes são de textura média.

As classes texturais na camada de 0 a $10 \mathrm{~cm}$ nas áreas sob pastagens estão classificadas entre areia franca para a pastagem (PA) no Latossolo, franco-arenosa para as pastagens $(\mathrm{P}),\left(\mathrm{PL}_{1}\right),\left(\mathrm{PL}_{2}\right)$ no Latossolo e a pastagem $\left(\mathrm{P} \arg _{2}\right)$ no Argissolo, e francoargilo-arenosa para a pastagem ( $\left.\mathrm{P} \arg _{1}\right)$ também no Argissolo. As áreas de cultivo com manga (M) no Latossolo e sob vegetação degradada (VD) no Argissolo foram classificadas também como franco-argilo-arenosa. Para as culturas anuais, foram classificadas como franco-arenosa para o Latossolo (CA) e franco-argilo-siltosa para o Argissolo (CA arg).

Para a camada de 10 a $20 \mathrm{~cm}$, os valores seguem a mesma tendência da camada superficial, com exceção as pastagens $\left(\mathrm{PL}_{1}\right)$ e $\left(\mathrm{PL}_{2}\right)$ no Latossolo e a pastagem ( $\mathrm{P}$ $\left.\arg _{2}\right)$ no Argissolo que passaram da classe franco-arenosa para franco-argilo-arenosa nesta camada. Observa-se ainda que para todos os usos nas duas classes de solos, os conteúdos de argila nesta camada são maiores que na camada superficial.

A textura pode ser considerada uma característica estável no solo e dessa forma, não está sujeita a alterações temporais curtas ou em função de tipos de manejos (FERREIRA et al., 2003). Mas a proporção de areia, de silte ou de argila na composição do solo influencia diretamente as propriedades físicas do solo, e consequentemente a infiltração, o armazenamento de água e a aeração deste.

A mudança textural somente ocorrerá se houver mudança da composição do solo devido à erosão seletiva ou dos processos de intemperismo, que ocorrem em escalas seculares ou milenares. Portanto, o uso e o manejo do solo afetam pouco a sua textura, implicando no fato de que, em área com classe textural similar, as variações da 
qualidade física estão associadas à variação de outras propriedades físicas (REINERT e REICHERT, 2006).

Com relação ao espaço poroso do solo, na Tabela 7 encontram-se os valores médios de macroporosidade, de microporosidade, de porosidade total e da densidade dos solos para as camadas de 0 a 10 e 10 a $20 \mathrm{~cm}$.

Foi observado para a macroporosidade que os valores variaram de 0,04 a $0,15 \mathrm{~m}^{3} \mathrm{~m}^{-3}$ no Latossolo e de 0,04 a $0,17 \mathrm{~m}^{3} \mathrm{~m}^{-3}$ no Argissolo para a camada superficial, com exceção as culturas anuais nas duas classes de solos e as pastagens ( $\left.\mathrm{P} \arg g_{1}\right)$ no Argissolo e $\left(\mathrm{PL}_{2}\right)$ no Latossolo, os valores de macroporosidade estão abaixo dos valores adequados para o bom desenvolvimento das culturas, que segundo Kiehl (1979) deve situar-se entre 0,10 a 0,16 $\mathrm{m}^{3} \mathrm{~m}^{-3}$. Estes solos estão suscetíveis a problemas com aeração e movimentação de água, pois de acordo com Silva et al. (2005), o fluxo de gases e o movimento de água no solo, estão intimamente relacionados ao seu volume de macroporos, ou seja, a garantia da oxigenação radicular, bem como a capacidade de infiltração e redistribuição de água no perfil dependem desta propriedade. Para as duas classes de solos, o menor valor de macroporosidade foi observado para as pastagens e o maior valor para as culturas anuais, isso ocorreu provavelmente pelo revolvimento do solo. Normalmente, o revolvimento do solo promove um aumento temporário da macroporosidade.

$\mathrm{Na}$ camada de 10 a $20 \mathrm{~cm}$ foram observados os maiores valores de macroporosidade para a cultura anual (CA) com $0,11 \mathrm{~m}^{3} \mathrm{~m}^{-3}$ no Latossolo e para a pastagem $\left(\mathrm{P} \arg _{1}\right) \operatorname{com} 0,12 \mathrm{~m}^{3} \mathrm{~m}^{-3}$ no Argissolo, sendo os menores para a pastagem (PA) com 0,04 $\mathrm{m}^{3}$ $\mathrm{m}^{-3}$ no Latossolo e para a pastagem $\left(\mathrm{P} \arg _{2}\right) \operatorname{com} 0,06 \mathrm{~m}^{3} \mathrm{~m}^{-3}$ no Argissolo. Os valores de macroporosidade nesta camada variaram entre 0,04 a $0,11 \mathrm{~m}^{3} \mathrm{~m}^{-3}$ no Latossolo e de 0,06 a $0,12 \mathrm{~m}^{3} \mathrm{~m}^{-3}$ no Argissolo. Observa-se que a macroporosidade foi influenciada pelo uso e pela cobertura do solo.

Geralmente solos com maiores teores de areia apresentam maior macroporosidade. A pastagem (PA) no Latossolo apresentou comportamento contrário, uma vez que foi observado para a mesma o maior conteúdo de areia em relação aos demais, porém, apresentou para as duas camadas estudadas o menor valor de macroporosidade. Tal fato pode estar relacionado com a compactação do solo, pois com a compactação ocorre a redução da macroporosidade. 
Tabela 7. Valores médios de macroporosidade $\left(\mathrm{m}^{3} \mathrm{~m}^{-3}\right)$, de microporosidade $\left(\mathrm{m}^{3} \mathrm{~m}^{-3}\right)$, de porosidade total $\left(\mathrm{m}^{3} \mathrm{~m}^{-3}\right)$, e da densidade do solo $\left(\mathrm{kg} \mathrm{dm}^{-3}\right)$, para as duas classes de solos, sob diferentes formas de uso e de ocupação, nas camadas de 0 a 10 e 10 a 20 $\mathrm{cm}$.

\begin{tabular}{|c|c|c|c|c|}
\hline \multirow{2}{*}{$\begin{array}{l}\text { Usos e ocupações } \\
\text { dos solos }\end{array}$} & \multirow{2}{*}{\multicolumn{3}{|c|}{ 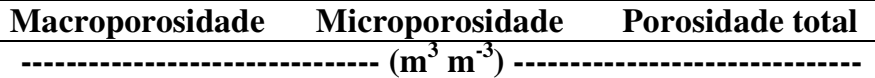 }} & \multirow{2}{*}{$\frac{\text { Densidade do solo }}{\left(\mathrm{kg} \mathrm{dm}^{-3}\right)}$} \\
\hline & & & & \\
\hline \multicolumn{5}{|c|}{ Camada 0 a $10 \mathrm{~cm}$} \\
\hline \multicolumn{5}{|c|}{ Latossolo Vermelho distrófico } \\
\hline M & $0,08 \mathrm{AB}^{*}$ & $0,26 \mathrm{~A}$ & $0,34 \mathrm{AB}$ & $1,59 \mathrm{~A}$ \\
\hline $\mathrm{P}$ & $0,07 \mathrm{AB}^{*}$ & $0,26 \mathrm{~A}$ & $0,33 \mathrm{AB}$ & $1,62 \mathrm{~A}$ \\
\hline PA & $0,04 \mathrm{~B} *$ & $0,30 \mathrm{~A}$ & $0,34 \mathrm{AB}$ & $1,61 \mathrm{~A}$ \\
\hline $\mathrm{PL}_{1}$ & $0,05 \mathrm{~B} *$ & $0,26 \mathrm{~A}$ & $0,31 \quad \mathrm{~B}$ & $1,68 \mathrm{~A}$ \\
\hline $\mathrm{PL}_{2}$ & $0,10 \mathrm{AB}^{*}$ & $0,30 \mathrm{~A}$ & $0,40 \mathrm{~A}$ & $1,49 \mathrm{~A}$ \\
\hline $\mathrm{CA}$ & $0,15 \mathrm{~A}^{*}$ & $0,24 \mathrm{~A}$ & $0,40 \mathrm{~A}$ & $1,57 \mathrm{~A}$ \\
\hline $\mathrm{CV}(\%)$ & 25,78 & 15,59 & 10,79 & 7,07 \\
\hline \multicolumn{5}{|c|}{ Argissolo Vermelho-Amarelo eutrófico } \\
\hline VD & $0,09 \quad \mathrm{BC}^{*}$ & $0,34 \mathrm{~A}$ & 0,44 B & $1,45 \mathrm{~A}$ \\
\hline $\mathrm{P} \arg _{1}$ & $0,11 \mathrm{AB}^{*}$ & $0,32 \mathrm{~A}$ & $0,43 \mathrm{~B}$ & $1,46 \mathrm{~A}$ \\
\hline CA arg & $0,17 \mathrm{~A}^{*}$ & $0,42 \mathrm{~A}$ & $0,59 \mathrm{~A}$ & $1,13 \mathrm{~B}$ \\
\hline $\mathrm{P} \arg _{2}$ & $0,04 \quad \mathrm{C}^{*}$ & $0,35 \mathrm{~A}$ & $0,39 \quad \mathrm{~B}$ & $1,48 \mathrm{~A}$ \\
\hline $\mathrm{CV}(\%)$ & 20,39 & 20,06 & 17,72 & 11,28 \\
\hline \multicolumn{5}{|c|}{ Camada 10 a $20 \mathrm{~cm}$} \\
\hline \multicolumn{5}{|c|}{ Latossolo Vermelho distrófico } \\
\hline M & $0,09 \mathrm{AB}^{*}$ & $0,26 \mathrm{~A}$ & $0,34 \mathrm{~A}$ & $1,55 \mathrm{~A}$ \\
\hline $\mathrm{P}$ & $0,06 \mathrm{AB}^{*}$ & $0,25 \mathrm{~A}$ & $0,31 \mathrm{~A}$ & $1,67 \mathrm{~A}$ \\
\hline PA & $0,04 \mathrm{~B} *$ & $0,28 \mathrm{~A}$ & $0,32 \mathrm{~A}$ & $1,65 \mathrm{~A}$ \\
\hline $\mathrm{PL}_{1}$ & $0,09 \mathrm{AB}^{*}$ & $0,25 \mathrm{~A}$ & $0,33 \mathrm{~A}$ & $1,64 \mathrm{~A}$ \\
\hline $\mathrm{PL}_{2}$ & $0,08 \mathrm{AB}^{*}$ & $0,28 \mathrm{~A}$ & $0,36 \mathrm{~A}$ & $1,56 \mathrm{~A}$ \\
\hline $\mathrm{CA}$ & $0,11 \mathrm{~A}^{*}$ & $0,27 \mathrm{~A}$ & $0,38 \mathrm{~A}$ & $1,62 \mathrm{~A}$ \\
\hline $\mathrm{CV}(\%)$ & 24,57 & 18,32 & 13,89 & 6,40 \\
\hline \multicolumn{5}{|c|}{ Argissolo Vermelho-Amarelo eutrófico } \\
\hline VD & $0,08 \mathrm{~A}^{*}$ & $0,34 \mathrm{AB}$ & $0,42 \mathrm{~A}$ & $1,51 \mathrm{~A}$ \\
\hline $\mathrm{P} \arg _{1}$ & $0,12 \mathrm{~A}^{*}$ & $0,31 \quad \mathrm{~B}$ & $0,43 \mathrm{~A}$ & $1,46 \mathrm{~A}$ \\
\hline $\mathrm{CA}$ arg & $0,09 \mathrm{~A}^{*}$ & $0,46 \mathrm{~A}$ & $0,55 \mathrm{~A}$ & $1,28 \mathrm{~A}$ \\
\hline $\mathrm{P} \arg _{2}$ & $0,06 \mathrm{~A}^{*}$ & $0,36 \mathrm{AB}$ & $0,42 \mathrm{~A}$ & $1,50 \mathrm{~A}$ \\
\hline $\mathrm{CV}(\%)$ & 23,61 & 19,23 & 21,54 & 13,86 \\
\hline
\end{tabular}

Médias seguidas de mesma letra, na coluna, não diferem estatisticamente entre si pelo teste de Tukey a 5\% de probabilidade.

* As letras são referentes à comparação dos dados transformados para raiz quadrada.

$\mathrm{M}=$ Cultura da manga, $\mathrm{P}=$ Pastagem, $\mathrm{PA}=$ Pastagem, $\mathrm{PL}_{1}=$ Pastagem, $\mathrm{PL}_{2}=$ Pastagem, $\mathrm{CA}=$ cultura anual, $\mathrm{VD}$ = Vegetação degradada com pequenos fragmentos de área com vegetação nativa, $\mathrm{P} \arg _{1}=\mathrm{Pastagem}_{\mathrm{C}} \mathrm{CA} \arg =$ Cultura anual e $\mathrm{P} \arg _{2}=$ Pastagem.

Observa-se para as duas camadas avaliadas que a macroporosidade apresentou valores próximos em ambos os solos, Queiroz (2008) ao avaliar estes mesmos solos, também encontrou médias semelhantes para os dois solos. 
Quanto à microporosidade, o maior valor observado no Latossolo foi para as pastagens (PA) e ( $\left.\mathrm{PL}_{2}\right)$, e para o Argissolo para a cultura anual (CA arg), nas duas camadas estudadas. Os valores de microporosidade variaram entre 0,24 a $0,30 \mathrm{~m}^{3} \mathrm{~m}^{-3}$ no Latossolo e de 0,32 a $0,42 \mathrm{~m}^{3} \mathrm{~m}^{-3}$ no Argissolo para a camada de 0 a $10 \mathrm{~cm}$, e de 0,25 a 0,28 $\mathrm{m}^{3} \mathrm{~m}^{-3}$ no Latossolo e de 0,31 a $0,46 \mathrm{~m}^{3} \mathrm{~m}^{-3}$ no Argissolo para a camada de 10 a $20 \mathrm{~cm}$.

Pode-se verificar que a microporosidade foi maior para o Argissolo independentemente do uso e ocupação do solo, estes resultados concordam com os obtidos por Queiroz (2008), que avaliando estes solos também observou maior microporosidade no Argissolo, e que este fato, está relacionado ao maior conteúdo de silte e de argila.

Observa-se que houve maior valor de microporos em relação à macroporos, o que pode ser atribuído não somente à textura dos solos, mas também devido à compactação destes. A compactação do solo tem sido verificada pelo aumento da densidade do solo e da microporosidade, e também da diminuição da porosidade total e, principalmente, da macroporosidade. Alguns autores associam a redução da macroporosidade com o aumento da microporosidade (MARCHÃO et al., 2007; FIGUEIREDO et al., 2009; MATIAS et al., 2009).

Por isso, torna-se importante verificar a relação entre macro e microporos, pois como descrito anteriormente, muitas vezes há um predomínio de microporos, ocorrendo densidades elevadas que podem dificultar o movimento de ar e água. Mas de acordo com Cavenage et al. (1999), este comportamento só irá ocorrer se a proporção de macroporos estiver abaixo do limite crítico considerado $\left(0,10 \mathrm{~m}^{3} \mathrm{~m}^{-3}\right)$.

A porosidade total e a densidade do solo são duas propriedades que estão diretamente relacionadas, quanto maior a densidade do solo, menores serão os valores de porosidade total. E isso foi evidenciado neste trabalho para a camada superficial nas duas classes de solo, uma vez que o maior valor de porosidade total no Latossolo foi encontrado para a cultura anual $(\mathrm{CA})$ e para a pastagem $\left(\mathrm{PL}_{2}\right)$, que apresentaram menor densidade do solo. $\mathrm{O}$ efeito contrário foi observado para a pastagem $\left(\mathrm{PL}_{1}\right)$ que apresentou a menor porosidade total e consequentemente maior densidade do solo. No Argissolo o maior valor foi observado para a cultura anual (CA arg), a qual apresentou menor densidade do solo, já na pastagem (P $\arg _{2}$ ) observou-se a menor porosidade total e consequentemente a maior densidade do solo. 
Os valores de porosidade total variaram de 0,31 a $0,40 \mathrm{~m}^{3} \mathrm{~m}^{-3}$ no Latossolo e de 0,39 a $0,59 \mathrm{~m}^{3} \mathrm{~m}^{-3}$ no Argissolo na camada de 0 a $10 \mathrm{~cm}$, e de 0,31 a $0,38 \mathrm{~m}^{3}$ $\mathrm{m}^{-3}$ no Latossolo e de 0,42 a $0,55 \mathrm{~m}^{3} \mathrm{~m}^{-3}$ no Argissolo para a camada de 10 a $20 \mathrm{~cm}$, nesta camada os usos e ocupações não diferiram entre si nas duas classes de solo. Observa-se que o maior valor foi encontrado para as culturas anuais nas duas classes de solos e nas duas camadas avaliadas. Para a camada de 10 a $20 \mathrm{~cm}$, os menores valores de porosidade total, foram encontrados para o Latossolo em todos os usos do solo.

De acordo com Kiehl (1979), a distribuição da porosidade total de um solo ideal deve ser de $0,50 \mathrm{~m}^{3} \mathrm{~m}^{-3}$, sendo a distribuição de percentual de $1 / 3$ para macroporos e 2/3 para microporos, ou seja, 0,17 e $0,33 \mathrm{~m}^{3} \mathrm{~m}^{-3}$, respectivamente. Neste trabalho, os valores de porosidade total nas duas classes de solos, com exceção à cultura anual no Argissolo (CA $\arg$ ), foram inferiores às condições ideais de $0,50 \mathrm{~m}^{3} \mathrm{~m}^{-3}$.

Com relação à densidade do solo, verificou-se que os maiores valores de densidade do solo para a camada superficial foram atribuídos para as pastagens nas duas classes de solos, sendo maiores para as pastagens $\left(\mathrm{PL}_{1}\right),(\mathrm{P})$ e (PA) no Latossolo, mostrando que estas são áreas bem compactadas, refletindo da menor macroporosidade das mesmas, devido ao pastoreio contínuo de animais. De acordo com Ceconi et al. (2007), em sistema de pastoreio contínuo além de favorecer a compactação do solo, há diminuição da qualidade das pastagens neste sistema, pois os animais percorrem maiores distâncias em busca de alimento e, consequentemente, o pastoreio é maximizado, aumentando a densidade do solo.

Para a camada 10 a $20 \mathrm{~cm}$, os maiores valores de densidade foram observados para o Latossolo nas áreas de cultura anual (CA) e das pastagens (P), (PA) e ( $\left.\mathrm{PL}_{1}\right)$. A cultura anual (CA) provavelmente apresentou maior densidade do solo para esta camada devido ao efeito causado pelo preparo convencional, o que também foi observado por Ceconi et al. (2007).

Os maiores valores de densidade do solo nas duas camadas foram encontrados para o Latossolo, pelo qual, também foram encontrados os menores valores de porosidade total. Este solo encontra-se em processo de degradação, merecendo bastante atenção quanto ao seu manejo.

Pode-se observar que os valores de densidade do solo para a camada superficial variaram entre 1,49 a $1,68 \mathrm{~kg} \mathrm{dm}^{-3}$ no Latossolo e de 1,13 a $1,48 \mathrm{~kg} \mathrm{dm}^{-3}$ no 
Argissolo. De acordo com Reichardt (1996) os valores normais para os solos arenosos podem variar de 1,4 a $1,8 \mathrm{~kg} \mathrm{dm}^{-3}$, enquanto solos argilosos apresentam valores mais baixos, de 0,9 a $1,6 \mathrm{~kg} \mathrm{dm}^{-3}$.

Para Reinert e Reichert (2006) valores de densidade do solo associados ao estado de compactação com alta probabilidade de oferecer riscos de restrição ao desenvolvimento das plantas, situam-se em torno de $1,65 \mathrm{~kg} \mathrm{dm}^{-3}$ para solos arenosos e 1,45 $\mathrm{kg} \mathrm{dm}^{-3}$ para solos argilosos. Os solos estudados se enquadram entre textura franco-arenosa e franco-argilo-arenosa, portanto, com exceção a cultura anual (CA arg) no Argissolo, os solos estudados estão próximos ao risco de compactação, sendo o valor mais crítico observado para a pastagem $\left(\mathrm{PL}_{1}\right)$ no Latossolo com $1,68 \mathrm{~kg} \mathrm{dm}^{-3}$.

Para a maioria dos usos nas duas classes de solos observa-se que os valores de densidade do solo na camada de 10 a $20 \mathrm{~cm}$ foram maiores. Segundo Figueiredo et al. (2009), em áreas com o uso intensivo do solo pode ocorrer entupimento dos seus poros, e consequentemente maior compactação do solo na camada subsuperficial. Além disso, o impacto direto das gotas da chuva sobre a superfície do solo desagrega os torrões, transformando-os em partículas menores, que são arrastadas para dentro dos poros.

Estes resultados também podem ser explicados pelo fato de que na superfície do solo, este apresenta maior quantidade de matéria orgânica, o que acaba reduzindo a densidade do solo quando comparada às camadas subsuperficiais.

Para o armazenamento de água no solo nas camadas de 0 a 10 e de 10 a $20 \mathrm{~cm}$, os valores médios encontram-se na Tabela 8 . Verifica-se que houve diferenças significativas nos valores médios de armazenamento de água para as duas classes de solos nos diferentes usos e ocupações do solo nas duas camadas analisadas.

No Latossolo o maior valor de armazenamento de água observado foi para a pastagem $\left(\mathrm{PL}_{1}\right)$ na camada de 0 a $10 \mathrm{~cm}$ e para a pastagem (PA) na camada de 10 a 20 $\mathrm{cm}$, e o menor valor foi observado para a pastagem $(\mathrm{P})$ nas duas camadas avaliadas. No Argissolo, em ambas as camadas, o maior valor de armazenamento de água foi para a pastagem ( $\left.\mathrm{P} \arg _{2}\right)$ e o menor para a vegetação degradada (VD). Os valores de armazenamento de água no solo variaram de 1,33 a 3,89 mm no Latossolo e de 2,29 a 5,75 mm no Argissolo para a camada de 0 a $10 \mathrm{~cm}$, e de 1,58 a 3,56 $\mathrm{mm}$ no Latossolo e de 2,66 a 4,54 $\mathrm{mm}$ no Argissolo para a camada de 10 a $20 \mathrm{~cm}$. 
Tabela 8. Valores médios de armazenamento de água no solo $(\mathrm{mm})$, para as duas classes de solos, sob diferentes formas de uso e de ocupação, nas camadas de 0 a 10 e 10 a 20 $\mathrm{cm}$.

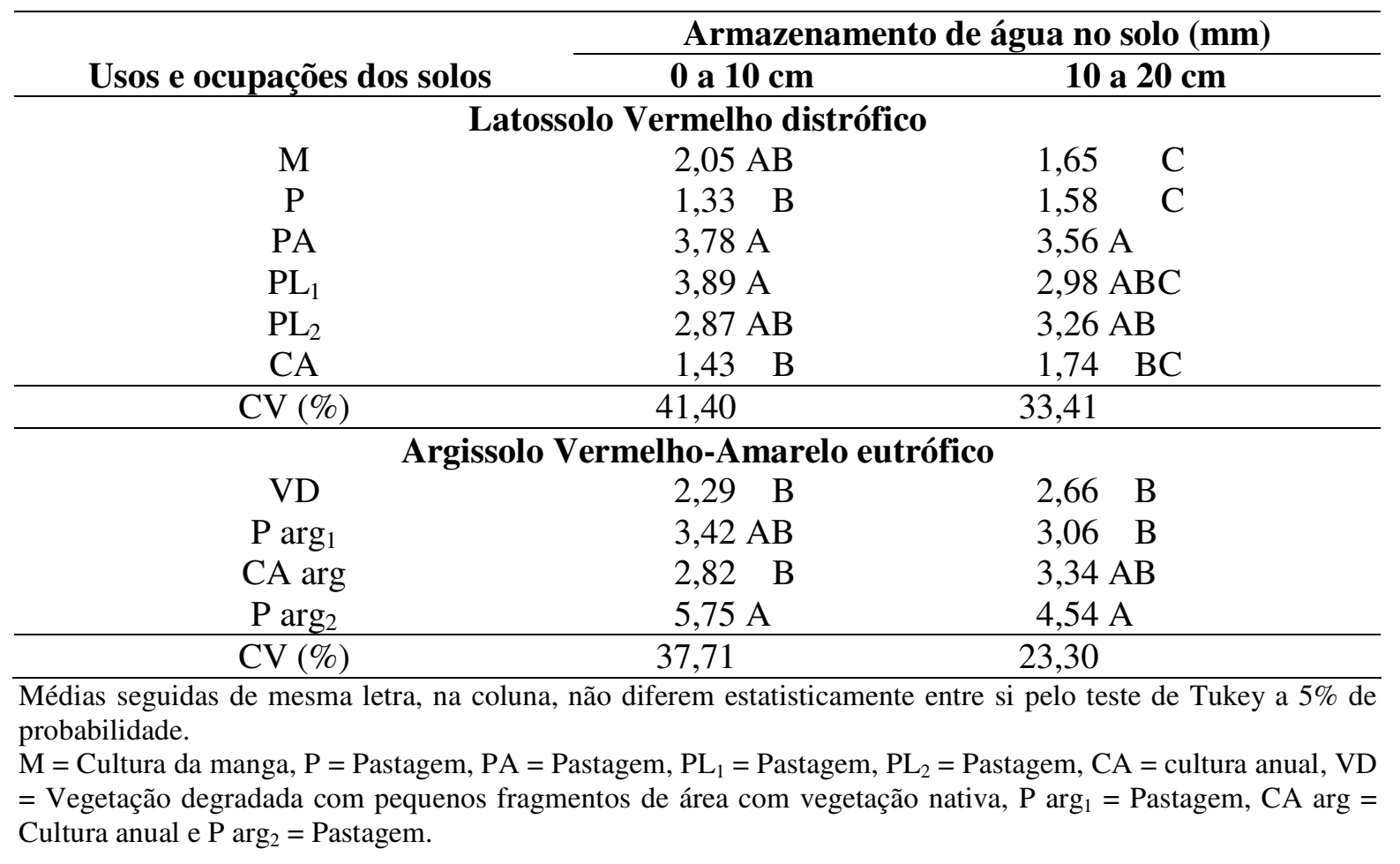

$\mathrm{O}$ armazenamento e a retenção de água no solo estão diretamente relacionados com a textura do solo. Solos com maiores teores de argila tendem a apresentar maior número de microporos, que são responsáveis pela retenção de água no solo.

Entretanto, não se pode prever sempre, para todas as classes de solo, a retenção de água somente a partir da textura. Isso se dá porque, além da textura são importantes os efeitos concorrentes, principalmente da estrutura e da porosidade (MESQUITA e MORAES, 2004).

No Latossolo os valores extremos de armazenamento de água no solo $\left(\mathrm{PL}_{1}\right)$ e $(\mathrm{P})$ se enquadraram na mesma classe textural, atentando que essa diferença não foi devido à textura dos solos e sim outra causa, relacionada à porosidade e a estrutura deste solo. Pois na área de pastagem (P) foi observada degradação da pastagem e como consequência, degradação do solo (Figura 10). 

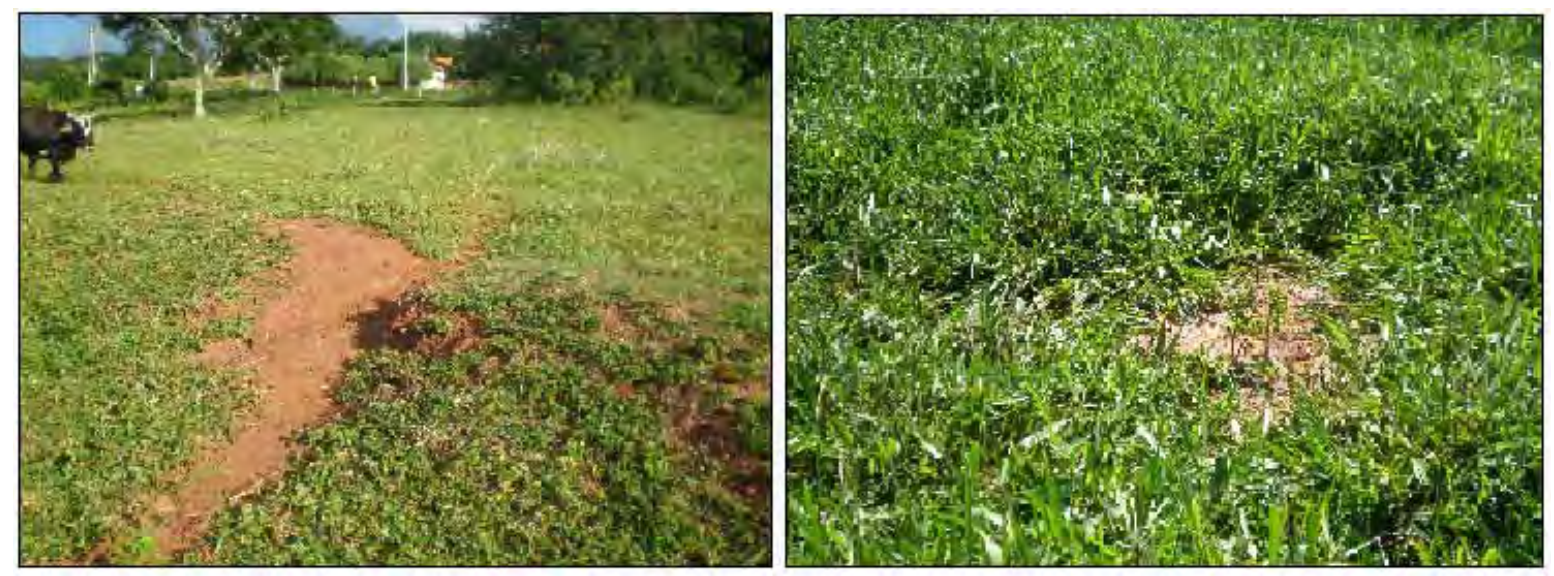

Figura 10. Pastagem degradada (P), no Latossolo.

A degradação das pastagens faz com que haja perda de vigor, de produtividade e da capacidade de recuperação natural, resultando no processo de aumento de densidade do solo na camada superficial e consequente redução da porosidade do solo (CAMARGO e ALLEONI, 1997).

Para Bertoni e Lombardi Neto (1990), as pastagens são consideradas boas coberturas do solo, entretanto, em consequência de práticas incorretas de manejo, como pouca ou nenhuma adubação e pastoreio excessivo, ocorre aumento da densidade do solo, redução da macroporosidade e queda na disponibilidade de forragem, devido à perda da capacidade de regeneração natural da pastagem e escassez de cobertura do solo, culminando na compactação do solo pelo pisoteio dos animais.

O arranjamento das partículas sólidas do solo durante o processo de compactação faz com que o espaço poroso do solo sofra redução, assim, ocorre uma diminuição da quantidade de água armazenável neste solo (CECONI et al., 2007).

Como observado no presente trabalho, Figueiredo et al. (2008) também verificaram que a degradação da pastagem causa diminuição na capacidade de armazenamento de água no solo. Para os mesmos, práticas de melhorias dos solos com o uso de adubação e correção, com consequente aumento da cobertura vegetal, promovem um ambiente mais propício para a formação de uma estrutura adequada para o armazenamento de água nestes solos. 
As culturas anuais em ambos os solos apresentaram menor valor de armazenamento de água no solo, sendo este menor no Latossolo. Sistemas de preparo que promovem maior revolvimento dos solos, como é o caso do plantio convencional, geralmente armazenam menos água na camada revolvida. Em outras palavras, com o revolvimento do solo aumenta o volume de poros, notadamente de macroporos, causando uma alteração na relação entre a microporosidade e a macroporosidade, refletindo-se na retenção de água. Portugal et al. (2008) também encontraram menor armazenamento de água em solo cultivado com cana devido ao revolvimento do solo realizado na implantação da cultura. A cultura anual no Argissolo (CA arg) apresentou maior armazenamento devido à textura, por ser um solo com maior conteúdo de argila e maior microporosidade, esta armazenou mais água, em comparação à cultura anual (CA) no Latossolo.

Os valores médios de retenção de água no solo retida às tensões de -10 , -150 e $-300 \mathrm{kPa}$, para as camadas de 0 a 10 e de 10 a $20 \mathrm{~cm}$ encontram-se na Tabela 9. Na camada de 0 a $10 \mathrm{~cm}$ os valores de retenção de água no solo variaram de 0,12 a $0,23 \mathrm{~m}^{3} \mathrm{~m}^{-3}$ no Latossolo e de 0,24 a $0,34 \mathrm{~m}^{3} \mathrm{~m}^{-3}$ no Argissolo para a tensão de $-10 \mathrm{kPa}$; de 0,10 a $0,19 \mathrm{~m}^{3} \mathrm{~m}^{-3}$ no Latossolo e de 0,23 a $0,33 \mathrm{~m}^{3} \mathrm{~m}^{-3}$ no Argissolo para a tensão de $-150 \mathrm{kPa}$; e de 0,08 a 0,20 $\mathrm{m}^{3} \mathrm{~m}^{-3}$ no Latossolo e de 0,21 a $0,32 \mathrm{~m}^{3} \mathrm{~m}^{-3}$ no Argissolo para a tensão de $-300 \mathrm{kPa}$. Na camada de 10 a $20 \mathrm{~cm}$ os valores de retenção de água no solo variaram de 0,12 a $0,22 \mathrm{~m}^{3} \mathrm{~m}^{-3}$ no Latossolo e de 0,25 a $0,38 \mathrm{~m}^{3} \mathrm{~m}^{-3}$ no Argissolo para a tensão de $-10 \mathrm{kPa}$; de 0,11 a $0,21 \mathrm{~m}^{3}$ $\mathrm{m}^{-3}$ no Latossolo e de 0,24 a $0,36 \mathrm{~m}^{3} \mathrm{~m}^{-3}$ no Argissolo para a tensão de $-150 \mathrm{kPa}$; de 0,09 a $0,21 \mathrm{~m}^{3} \mathrm{~m}^{-3}$ no Latossolo e de 0,22 a $0,34 \mathrm{~m}^{3} \mathrm{~m}^{-3}$ no Argissolo para a tensão de $-300 \mathrm{kPa}$.

Comparando as duas classes de solos, pode-se observar que os maiores valores de retenção de água no solo foi para a cultura anual (CA arg) no Argissolo, em todas as tensões para as duas camadas. Já os menores valores foram atribuídos para a pastagem (PA) no Latossolo. Diante disso, observa-se a influência do tamanho dos poros na retenção de água no solo, uma vez que, a cultura anual (CA arg) apresentou o maior valor de microporosidade e conteúdo de argila, obtendo o maior valor de retenção de água no solo. Por outro lado, a pastagem (PA) apresentou um dos menores valores de microporos e também o maior conteúdo de areia, consequentemente, menor retenção de água. 
Tabela 9. Valores médios de retenção de água no solo $\left(\mathrm{m}^{3} \mathrm{~m}^{-3}\right)$ retida às tensões de $-10,-150 \mathrm{e}$ $-300 \mathrm{kPa}$, para as duas classes de solos, sob diferentes formas de uso e de ocupação, nas camadas de 0 a 10 e 10 a $20 \mathrm{~cm}$.

\begin{tabular}{|c|c|c|c|}
\hline \multirow{2}{*}{$\begin{array}{l}\text { Usos e ocupações } \\
\text { dos solos }\end{array}$} & \multicolumn{3}{|c|}{ Retenção de água no solo $\left(\mathrm{m}^{3} \mathrm{~m}^{-3}\right)$} \\
\hline & $-10 \mathrm{kPa}$ & $-150 \mathrm{kPa}$ & $-300 \mathrm{kPa}$ \\
\hline \multicolumn{4}{|c|}{ Camada de 0 a $10 \mathrm{~cm}$} \\
\hline \multicolumn{4}{|c|}{ Latossolo Vermelho distrófico } \\
\hline M & $0,20 \mathrm{AB}$ & $0,19 \mathrm{AB}$ & $0,18 \mathrm{~A}$ \\
\hline $\mathrm{P}$ & $0,20 \mathrm{AB}$ & $0,19 \mathrm{AB}$ & $0,18 \mathrm{~A}$ \\
\hline PA & $0,12 \quad \mathrm{~B}$ & $0,10 \quad \mathrm{~B}$ & $0,08 \quad \mathrm{~B}$ \\
\hline $\mathrm{PL}_{1}$ & $0,19 \mathrm{AB}$ & $0,18 \mathrm{AB}$ & $0,15 \mathrm{AB}$ \\
\hline $\mathrm{PL}_{2}$ & $0,23 \mathrm{~A}$ & $0,22 \mathrm{~A}$ & $0,20 \mathrm{~A}$ \\
\hline $\mathrm{CA}$ & $0,19 \mathrm{AB}$ & $0,18 \mathrm{AB}$ & $0,18 \mathrm{~A}$ \\
\hline $\mathrm{CV}(\%)$ & 28,08 & 29,73 & 30,51 \\
\hline \multicolumn{4}{|c|}{ Argissolo Vermelho-Amarelo eutrófico } \\
\hline VD & $0,24 \mathrm{~A}$ & $0,23 \mathrm{~A}$ & $0,22 \mathrm{~A}$ \\
\hline $\mathrm{P} \arg _{1}$ & $0,29 \mathrm{~A}$ & $0,27 \mathrm{~A}$ & $0,25 \mathrm{~A}$ \\
\hline $\mathrm{CA}$ arg & $0,34 \mathrm{~A}$ & $0,33 \mathrm{~A}$ & $0,32 \mathrm{~A}$ \\
\hline $\mathrm{P} \arg _{2}$ & $0,27 \mathrm{~A}$ & $0,23 \mathrm{~A}$ & $0,21 \mathrm{~A}$ \\
\hline $\mathrm{CV}(\%)$ & 27,65 & 30,93 & 33,47 \\
\hline \multicolumn{4}{|c|}{ Camada 10 a $20 \mathrm{~cm}$} \\
\hline \multicolumn{4}{|c|}{ Latossolo Vermelho distrófico } \\
\hline M & $0,20 \mathrm{~A}$ & $0,19 \mathrm{~A}$ & $0,18 \mathrm{AB}$ \\
\hline $\mathrm{P}$ & $0,19 \mathrm{~A}$ & $0,18 \mathrm{~A}$ & $0,17 \mathrm{AB}$ \\
\hline PA & $0,12 \mathrm{~A}$ & $0,11 \mathrm{~A}$ & $0,09 \quad \mathrm{~B}$ \\
\hline $\mathrm{PL}_{1}$ & $0,16 \mathrm{~A}$ & $0,15 \mathrm{~A}$ & $0,13 \mathrm{AB}$ \\
\hline $\mathrm{PL}_{2}$ & $0,21 \mathrm{~A}$ & $0,19 \mathrm{~A}$ & $0,18 \mathrm{AB}$ \\
\hline $\mathrm{CA}$ & $0,22 \mathrm{~A}$ & $0,21 \mathrm{~A}$ & $0,21 \mathrm{~A}$ \\
\hline $\mathrm{CV}(\%)$ & 29,00 & 30,90 & 32,66 \\
\hline \multicolumn{4}{|c|}{ Argissolo Vermelho-Amarelo eutrófico } \\
\hline VD & $0,25 \quad \mathrm{~B}$ & $0,24 \mathrm{~A}$ & $0,22 \mathrm{~A}$ \\
\hline $\mathrm{P} \arg _{1}$ & $0,27 \mathrm{AB}$ & $0,26 \mathrm{~A}$ & $0,24 \mathrm{~A}$ \\
\hline CA arg & $0,38 \mathrm{~A}$ & $0,36 \mathrm{~A}$ & $0,34 \mathrm{~A}$ \\
\hline $\mathrm{P} \arg _{2}$ & $0,29 \mathrm{AB}$ & $0,26 \mathrm{~A}$ & $0,25 \mathrm{~A}$ \\
\hline $\mathrm{CV}(\%)$ & 22,38 & 24,32 & 26,56 \\
\hline
\end{tabular}

Médias seguidas de mesma letra, na coluna, não diferem estatisticamente entre si pelo teste de Tukey a $5 \%$ de probabilidade.

$\mathrm{M}=$ Cultura da manga, $\mathrm{P}=$ Pastagem, $\mathrm{PA}=$ Pastagem, $\mathrm{PL}_{1}=$ Pastagem, $\mathrm{PL}_{2}=$ Pastagem, $\mathrm{CA}=$ cultura anual, $\mathrm{VD}$ = Vegetação degradada com pequenos fragmentos de área com vegetação nativa, $\mathrm{P} \arg _{1}=\mathrm{Pastagem}_{\mathrm{C}} \mathrm{CA} \arg =$ Cultura anual e $\mathrm{P} \arg _{2}=$ Pastagem.

No geral, observa-se para todas as tensões nas duas camadas estudadas, maiores valores de retenção de água para o Argissolo. De acordo com Figueiredo et al. (2008), os Latossolos do cerrado são solos que apresentam baixa retenção de água, devido principalmente, à composição oxídica da fração argila e a presença de estrutura do tipo granular. 
Como verificado anteriormente, algumas propriedades físicas do solo podem ser alteradas pelas práticas de manejo e, dessa maneira a infiltração de água e a condutividade hidráulica do solo modifica-se.

A permeabilidade do solo depende, dentre outros fatores, da quantidade, da continuidade e do tamanho de poros, sendo a compactação e a descontinuidade dos poros responsáveis pela redução significativa da permeabilidade do solo à água. $\mathrm{O}$ conhecimento da infiltração da água no solo e da condutividade hidráulica é fundamental para a solução de problemas relativos à conservação da água e do solo, e controle do escoamento superficial, sendo de grande importância para o manejo do solo e da água o entendimento do processo de infiltração e de suas relações com as propriedades do solo (SOUZA e ALVEZ, 2003).

$\mathrm{Na}$ Tabela 10 encontram-se os valores médios de taxa constante de infiltração de água no solo e de condutividade hidráulica do solo saturado para a superfície do solo, para as duas classes de solos sob diferentes formas de uso e de ocupação. Foram verificadas diferenças significativas para os valores médios de taxa constante de infiltração nas duas classes de solos para os diferentes usos do solo, o que evidencia a influencia do tipo de cobertura do solo sobre a infiltração do mesmo. Para a condutividade hidráulica do solo saturado houve diferença significativa entre os usos e ocupações somente para o Latossolo.

Os valores de taxa constante de infiltração de água para a superfície do solo variaram de 11,81 a $81,27 \mathrm{~cm} \mathrm{~h}^{-1}$ no Latossolo e de 13,77 a $54,86 \mathrm{~cm} \mathrm{~h}^{-1}$ no Argissolo. Os valores de condutividade hidráulica do solo saturado variaram de 1,69 a $18,41 \mathrm{~cm} \mathrm{~h}^{-1}$ no Latossolo e de 2,11 a 4,47 $\mathrm{cm} \mathrm{h}^{-1}$ no Argissolo. 
Tabela 10. Valores médios de taxa constante de infiltração e de condutividade hidráulica do solo saturado $\left(\mathrm{cm} \mathrm{h}^{-1}\right)$, para as duas classes de solos, sob diferentes formas de uso e de ocupação, na superfície do solo.

\begin{tabular}{|c|c|c|}
\hline Usos e ocupações dos solos & Taxa constante de infiltração $\left(\mathrm{cm} \mathrm{h}^{-1}\right)$ & Condutividade hidráulica $\left(\mathrm{cm} \mathrm{h}^{-1}\right)$ \\
\hline \multicolumn{3}{|c|}{ Latossolo Vermelho distrófico } \\
\hline M & 11,81 & 1,69 \\
\hline $\mathrm{P}$ & 14,00 & 2,47 \\
\hline PA & $42,77 \quad B^{*}$ & $12,90 \mathrm{~A}^{*}$ \\
\hline $\mathrm{PL}_{1}$ & $17,77 \quad C^{*}$ & 2,95 \\
\hline $\mathrm{PL}_{2}$ & $21,91 \quad \mathrm{BC}^{*}$ & 3,47 \\
\hline CA & $81,27 \mathrm{~A}^{*}$ & $18,41 \mathrm{~A}^{*}$ \\
\hline $\mathrm{CV}(\%)$ & 20,36 & 26,23 \\
\hline \multicolumn{3}{|c|}{ Argissolo Vermelho-Amarelo eutrófico } \\
\hline VD & $15,68 \quad B^{*}$ & $2,11 \mathrm{~A}^{*}$ \\
\hline $\mathrm{P} \arg _{1}$ & $13,77 \quad \mathrm{~B}^{*}$ & 2,39 A* \\
\hline CA arg & $54,86 \mathrm{~A} *$ & $4,47 \mathrm{~A}^{*}$ \\
\hline $\mathrm{P} \arg _{2}$ & $20,91 \quad B^{*}$ & $3,89 \mathrm{~A}^{*}$ \\
\hline $\mathrm{CV}(\%)$ & 30,70 & 37,84 \\
\hline
\end{tabular}

Médias seguidas de mesma letra, na coluna, não diferem estatisticamente entre si pelo teste de Tukey a 5\% de probabilidade.

* As letras são referentes à comparação dos dados transformados para raiz quadrada.

$\mathrm{M}=$ Cultura da manga, $\mathrm{P}=$ Pastagem, $\mathrm{PA}=$ Pastagem, $\mathrm{PL}_{1}=$ Pastagem, $\mathrm{PL}_{2}=$ Pastagem, $\mathrm{CA}=$ cultura anual, $\mathrm{VD}$

$=$ Vegetação degradada com pequenos fragmentos de área com vegetação nativa, $\mathrm{P} \arg _{1}=$ Pastagem, $\mathrm{CA} \arg =$ Cultura anual e $\mathrm{P} \arg _{2}=$ Pastagem.

Nas Figuras 11, 12 e 13 estão apresentados os gráficos da infiltração média acumulada em função do tempo para a superfície do solo. No geral, os valores da correlação $\mathrm{R}^{2}$, estão próximos de 1 , o que mostra um bom ajuste da curva aos pontos experimentais. Os diferentes usos e ocupações do solo mostraram diferenças na infiltração média acumulada, sendo observado para as duas classes de solos maior infiltração para as culturas anuais. Observa-se também que para um mesmo tempo de infiltração, esta é maior para o Latossolo, devido ao maior conteúdo de areia deste solo quando comparado com o Argissolo. 

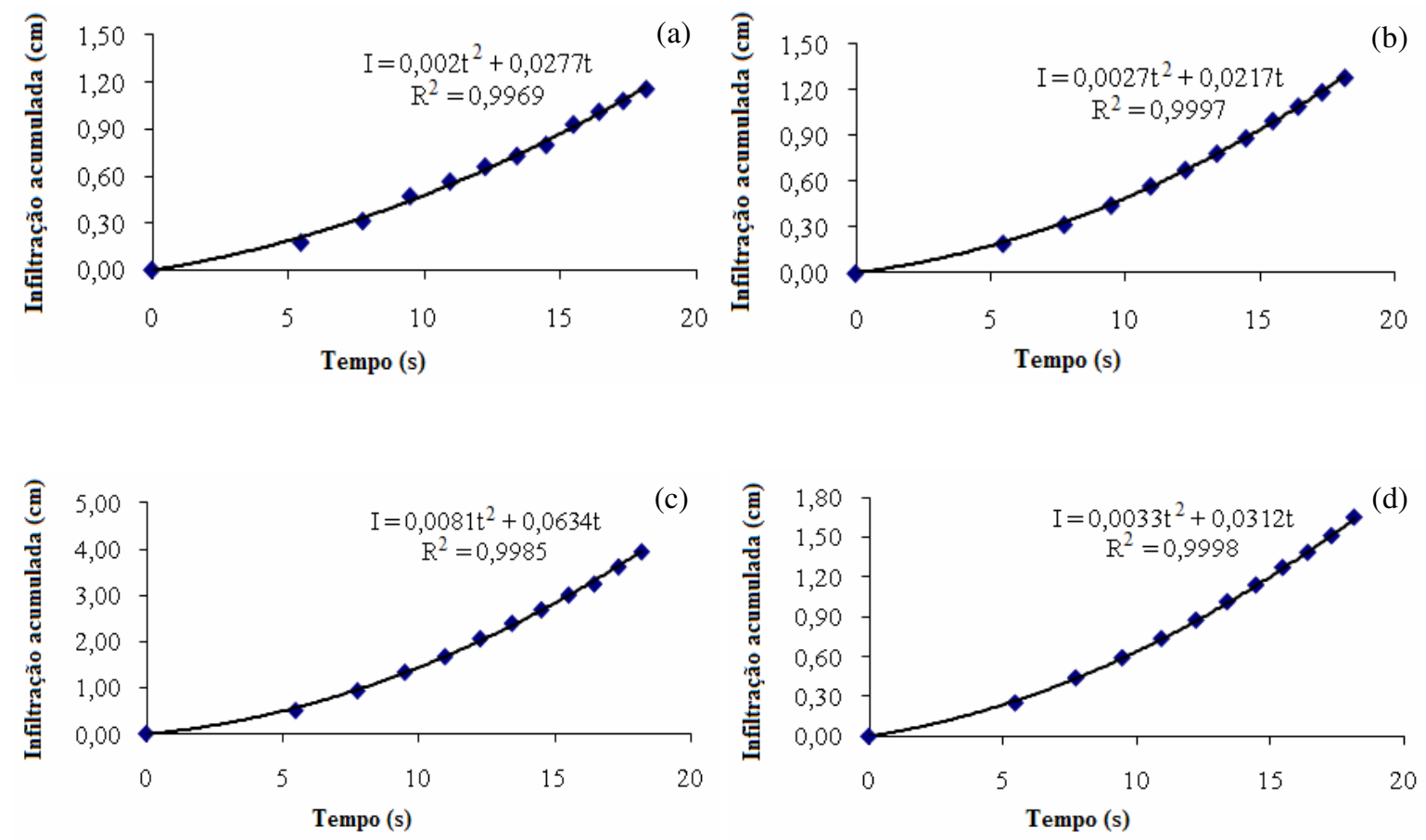

(e)
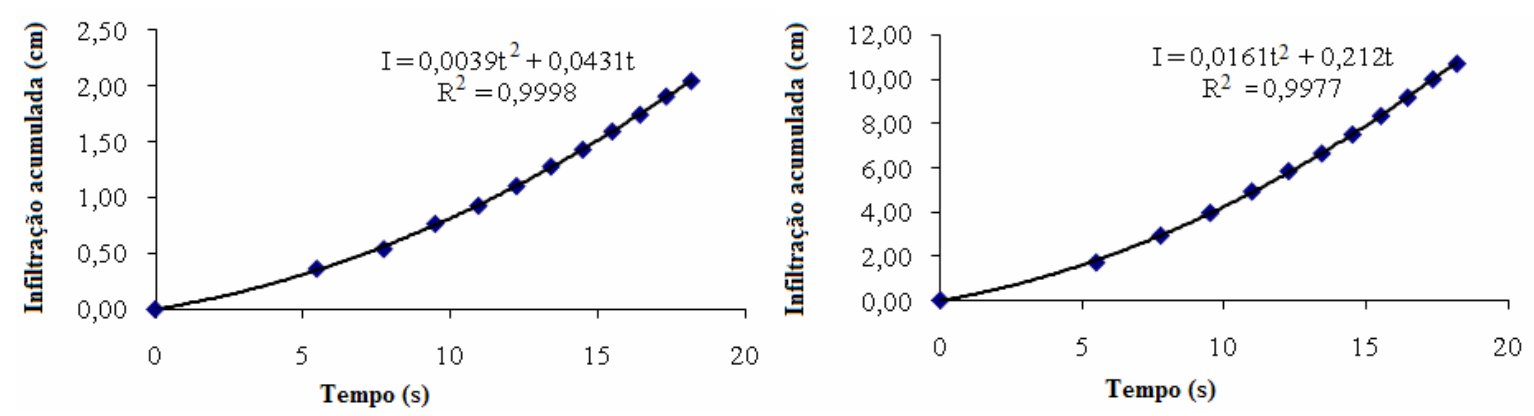

Figura 11. Infiltração média acumulada $(\mathrm{cm})$, para o Latossolo Vermelho distrófico nos diferentes usos e manejos: (a) Cultura da manga; (b), (c), (d), (e) Pastagem e (f) Cultura anual. 


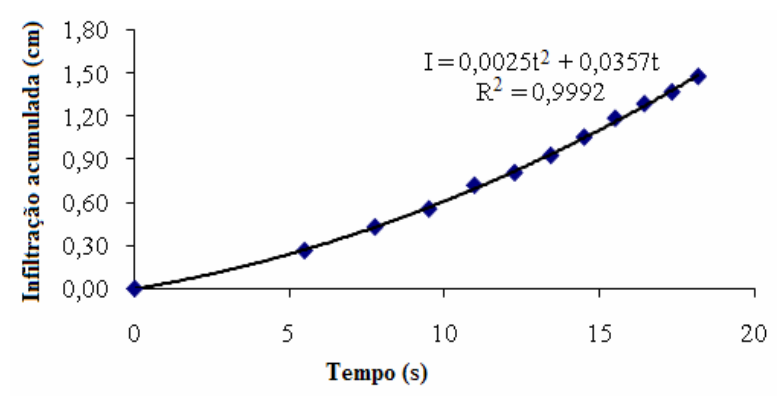

Figura 12. Infiltração média acumulada $(\mathrm{cm})$, para a Vegetação degradada com pequenos fragmentos remanescentes de área com vegetação nativa, em área de transição entre o Latossolo Vermelho distrófico e o Argissolo Vermelho-Amarelo eutrófico.
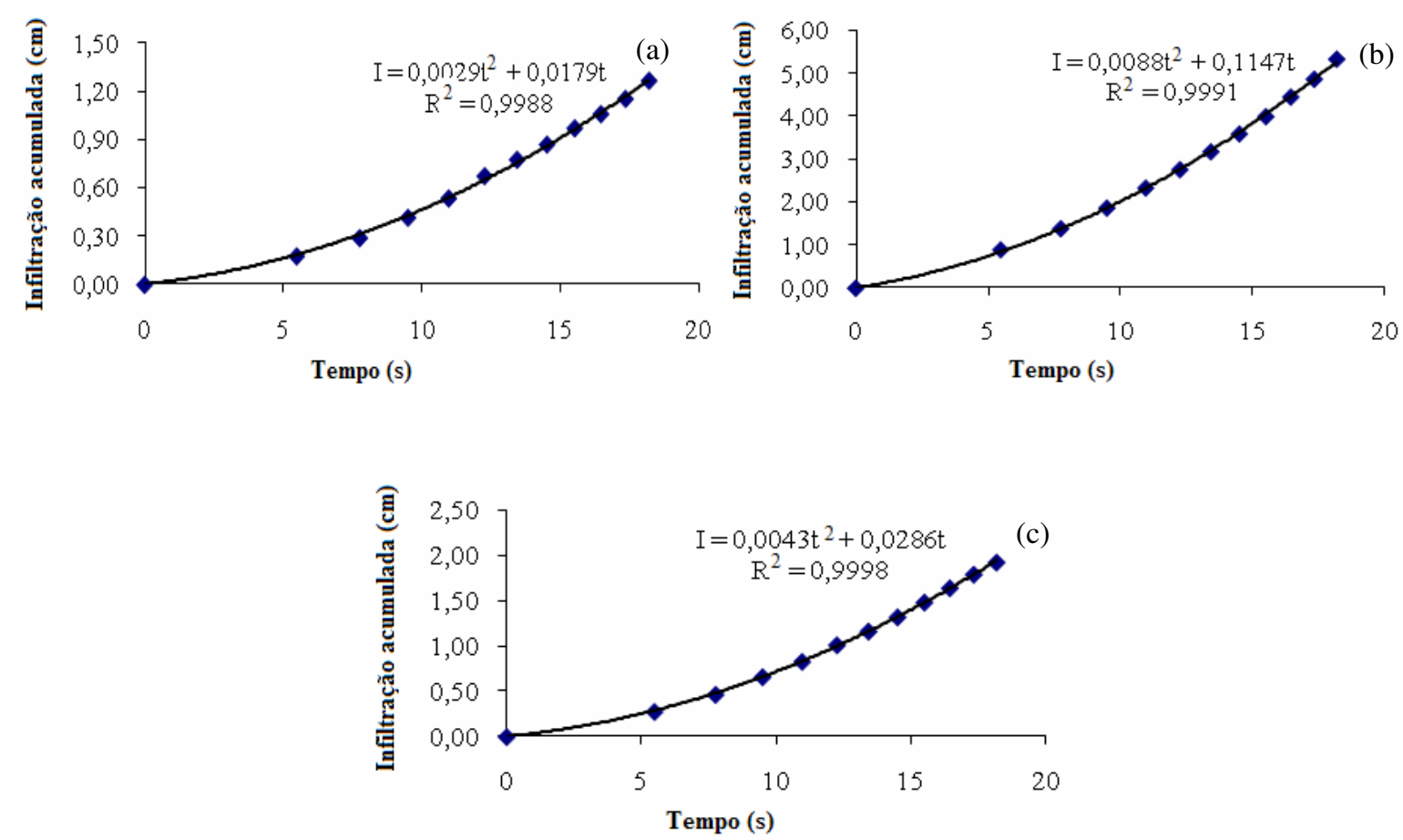

Figura 13. Infiltração média acumulada $(\mathrm{cm})$, para o Argissolo Vermelho-Amarelo nos diferentes usos e manejos: (a), (c) Pastagem e (b) Cultura anual.

Assim como para a infiltração acumulada, o maior valor de taxa constante de infiltração de água no solo foi verificado para as culturas anuais nas duas classes 
de solos, sendo maior para o Latossolo. Este maior valor de taxa constante de infiltração para as culturas anuais ocorreu provavelmente, devido ao preparo convencional do solo. Quando se prepara o solo, a capacidade de infiltração tende a aumentar, em razão da quebra da estrutura da camada superficial.

Observa-se que para um mesmo uso de solo houve diferença entre os valores encontrados para as duas classes de solos, sendo encontrado um valor de taxa constante de infiltração menor para o Argissolo. O que pode ser atribuído para este menor valor é o maior conteúdo de silte e de argila presente neste solo.

Solos arenosos tendem a ser mais permeáveis que os solos argilosos, por possuírem maior macroporosidade. Silva (2003) salienta que, solos com maior macroporosidade permitem uma maior movimentação de água, uma vez que dispõe de maior área de transporte. O que deve ser considerado também com relação ao movimento de água no solo não é somente o tamanho do poro, mas a continuidade dos mesmos, pois pequenos poros podem conduzir mais água quando estes são contínuos.

Nas áreas com culturas anuais, pelo fato de haver o revolvimento do solo no momento do preparo, a infiltração foi maior do que nas áreas com pastagens em ambos os solos. Solos situados em áreas de pastagem sofrem intensa compactação, ocasionada pelo pastoreio dos animais. Estes resultados concordam com Queiroz (2008), Pinheiro et al. (2009) e Centurion et al. (2001).

O menor valor de taxa constante de infiltração no Latossolo foi encontrado para o solo sob cultivo de manga (M) com 11,81 $\mathrm{cm} \mathrm{h}^{-1}$, seguido da pastagem (P) com $14,00 \mathrm{~cm} \mathrm{~h}^{-1}$, provavelmente devido o solo destas áreas se encontrarem compactados. Solos compactados apresentam menor quantidade de poros, e consequentemente, menores valores de infiltração. A compactação do solo é um grave problema em sistema de pastejo, devido entre outros fatores, ao excesso de animais por área (superpastejo). Em pomares, a compactação geralmente ocorre devido ao tráfego intenso de máquinas para as operações de manutenção do pomar. Mas para a área com a cultura da manga (M), isto não ocorreu devido a este fator, uma vez que não há a utilização destas práticas. O que pode ser atribuído a isto, é o fato de que, nesta área há pastejo de animais, pois o proprietário coloca-os na área para que os mesmos se alimentem das frutas que caem sobre o solo, promovendo assim, uma maior compactação do mesmo. 
Para o Argissolo o menor valor de taxa constante de infiltração foi observado para a pastagem $\left(\mathrm{P} \arg _{1}\right)\left(13,77 \mathrm{~cm} \mathrm{~h}^{-1}\right)$. A vegetação degradada (VD) também apresentou um valor baixo de taxa constante de infiltração $\left(15,68 \mathrm{~cm} \mathrm{~h}^{-1}\right)$, isso ocorreu provavelmente, pelo fato do solo apresentar alta densidade do solo e baixa macroporosidade.

Para a superfície do solo, os valores de taxa constante de infiltração foram classificados entre moderado, moderado a rápido e rápido. Sendo moderado para a área cultivada com manga (M) no Latossolo, moderado a rápido para a vegetação degradada (VD) no Argissolo e para as pastagens em ambos os solos, exceto para a pastagem (PA) no Latossolo, que foi classificado como rápido. As culturas anuais para os dois solos estudados foram classificadas como rápido, segundo a classificação de Soil Survey Staff (1993).

Assim como observado no presente trabalho, Souza e Alves (2003) também verificaram que as diferentes formas de uso e de manejo do solo promoveram alterações na infiltração de água, pois a mesma indica as diferenças no comportamento hidrodinâmico do solo em função da alteração de sua estrutura, considerando que tais modificações são acentuadas em função do manejo.

Quanto à condutividade hidráulica do solo saturado na superfície do solo, os maiores valores verificados para o Latossolo foram para a cultura anual (CA) seguido da pastagem (PA). Este maior valor de condutividade hidráulica do solo saturado encontrado para a cultura anual com $18,41 \mathrm{~cm} \mathrm{~h}^{-1}$ é provavelmente devido ao revolvimento do solo nesta camada durante o preparo, o que levou ao destorroamento do mesmo, aumentando assim o número de macroporos. Estes resultados concordam com Silva et al. (2005), que também encontraram maiores valores de condutividade hidráulica para o solo sob plantio convencional.

Para o solo cultivado com manga (M), onde se observou o menor valor de condutividade com 1,69 $\mathrm{cm} \mathrm{h}^{-1}$, ocorreu o processo contrário por ser uma área bastante compactada. De acordo com Ottoni Filho (2003), a condutividade hidráulica é uma das grandezas pedológicas que mais diz respeito aos processos dinâmicos nos vazios do solo.

No Argissolo o maior valor de condutividade hidráulica também foi observado para a cultura anual (CA $\arg$ ) $\operatorname{com} 4,47 \mathrm{~cm} \mathrm{~h}^{-1}$. Já o menor valor, foi verificado para a vegetação degradada (VD) com $2,11 \mathrm{~cm} \mathrm{~h}^{-1}$. Neste solo, os usos e ocupações não diferiram estatisticamente entre si, e assim como para a taxa constante de infiltração e a infiltração 
acumulada, os valores de condutividade hidráulica foram menores quando comparados ao Latossolo.

Assim como a infiltração de água no solo, a condutividade hidráulica é mais dependente da estrutura do que da textura do solo. As práticas culturais adotadas alterando a estrutura do solo influenciam diretamente na mesma. Com os distintos usos do solo a porosidade se modifica. Paralelamente a isto, deve-se modificar também a condutividade. A magnitude destas modificações estruturais ocasionadas pelo manejo depende da ocorrência e da frequência das operações de práticas agrícolas superficiais e subsuperficiais no solo e, também, do efeito compactante produzido pelo trânsito do maquinário agrícola ou de animais (MESQUITA e MORAES, 2004).

De acordo com a classificação de Soil Survey Staff (1993), na superfície do solo os valores de condutividade hidráulica do solo saturado foram classificados entre lento, lento a moderado e moderado a rápido. Sendo lento para a cultura da manga (M) no Latossolo, lento a moderado para a vegetação degradada (VD) no Argissolo, para a cultura anual (CA arg) no Argissolo, e para as pastagens em ambos os solos, exceto (PA) no Latossolo que foi classificado como moderado a rápido. Para cultura anual (CA) no Latossolo também foi classificado como moderado a rápido.

$\mathrm{Na}$ Tabela 11 encontram-se os valores médios de taxa constante de infiltração de água no solo para as profundidades de 10 e de $20 \mathrm{~cm}$. Observa-se que não houve diferença significativa nos valores médios de taxa constante de infiltração nos diferentes usos e ocupações nas duas classes de solos, para as duas profundidades analisadas.

Os valores de taxa constante de infiltração de água no solo variaram de 0,07 a $0,95 \mathrm{~cm} \mathrm{~h}^{-1}$ no Latossolo e de 0,04 a $0,35 \mathrm{~cm} \mathrm{~h}^{-1}$ no Argissolo para a profundidade de 10 $\mathrm{cm}$, e de 0,01 a $0,30 \mathrm{~cm} \mathrm{~h}^{-1}$ no Latossolo e de 0,03 a $0,17 \mathrm{~cm} \mathrm{~h}^{-1}$ no Argissolo para a profundidade de $20 \mathrm{~cm}$. Na profundidade de $10 \mathrm{~cm}$ os maiores valores de taxa constante de infiltração foram observados para as culturas anuais em ambos os solos, devido ao preparo convencional. No Latossolo, também foi observado um maior valor de taxa constante de infiltração para a pastagem (PA), por ser uma área com alto conteúdo de areia. Para a profundidade de $20 \mathrm{~cm}$ o maior valor de taxa constante de infiltração foi observado para a pastagem (PA) seguido da pastagem $\left(\mathrm{PL}_{2}\right)$ no Latossolo, e para a cultura anual (CA arg) no Argissolo. 
Tabela 11. Valores médios de taxa constante de infiltração $\left(\mathrm{cm} \mathrm{h}^{-1}\right)$, para as duas classes de solos, sob diferentes formas de uso e de ocupação, nas profundidades de 10 e de 20 $\mathrm{cm}$.

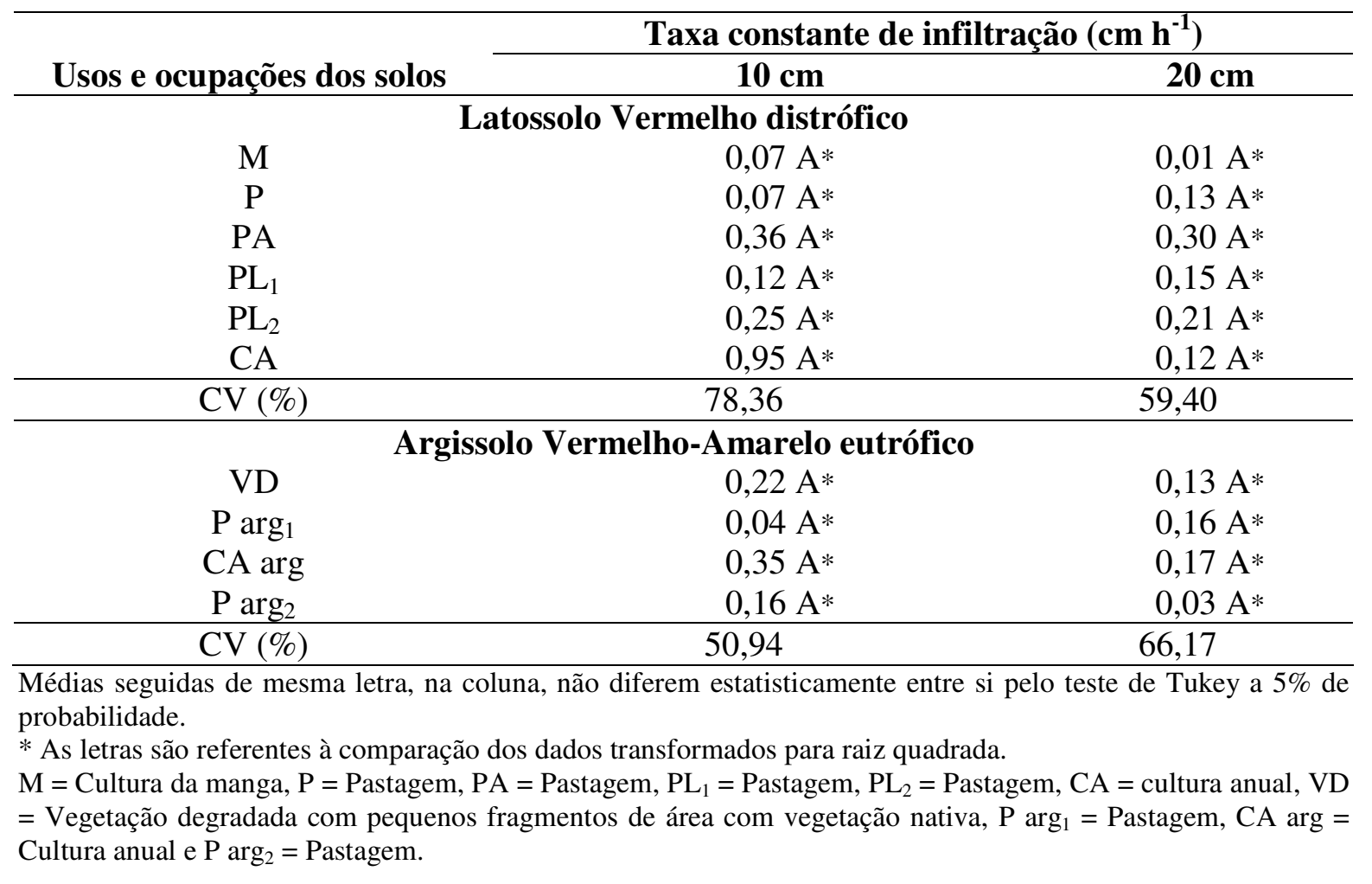

Os valores de taxa constante de infiltração foram considerados muito lentos nas profundidades de 10 e de $20 \mathrm{~cm}$ para todos os usos e em ambos os solos, com exceção a cultura anual (CA) no Latossolo que, para a profundidade de $10 \mathrm{~cm}$, foi classificado como lento de acordo com a classificação de Soil Survey Staff (1993).

Quanto à condutividade hidráulica do solo saturado os valores médios para as profundidades de 10 e de $20 \mathrm{~cm}$ encontram-se na Tabela 12. Para a condutividade hidráulica também não houve diferença significativa entre os diferentes usos e ocupações nas duas classes de solos, para as duas profundidades avaliadas. 
Tabela 12. Valores médios de condutividade hidráulica do solo saturado $\left(\mathrm{cm} \mathrm{h}^{-1}\right)$, para as duas classes de solos, sob diferentes formas de uso e de ocupação, nas profundidades de 10 e de $20 \mathrm{~cm}$.

\begin{tabular}{|c|c|c|}
\hline \multirow[b]{2}{*}{ Usos e ocupaç̃̃es dos solos } & \multicolumn{2}{|c|}{ Condutividade hidráulica $\left(\mathrm{cm} \mathrm{h}^{-1}\right)$} \\
\hline & $10 \mathrm{~cm}$ & $20 \mathrm{~cm}$ \\
\hline \multicolumn{3}{|c|}{ Latossolo Vermelho distrófico } \\
\hline M & $0,14 \mathrm{~A}^{*}$ & $0,02 \mathrm{~A} *$ \\
\hline $\mathrm{P}$ & $0,05 \mathrm{~A} *$ & $0,14 \mathrm{~A}^{*}$ \\
\hline PA & $0,22 \mathrm{~A} *$ & $0,19 \mathrm{~A}^{*}$ \\
\hline $\mathrm{PL}_{1}$ & $0,10 \mathrm{~A} *$ & $0,10 \mathrm{~A} *$ \\
\hline $\mathrm{PL}_{2}$ & $0,36 \mathrm{~A} *$ & $0,27 \mathrm{~A} *$ \\
\hline $\mathrm{CA}$ & $0,70 \mathrm{~A} *$ & $0,13 \mathrm{~A}^{*}$ \\
\hline $\mathrm{CV}(\%)$ & 87,80 & 59,04 \\
\hline \multicolumn{3}{|c|}{ Argissolo Vermelho-Amarelo eutrófico } \\
\hline VD & $0,09 \mathrm{~A} *$ & $0,07 \mathrm{~A}^{*}$ \\
\hline $\mathrm{P} \arg _{1}$ & $0,14 \mathrm{~A}^{*}$ & $0,25 \mathrm{~A} *$ \\
\hline $\mathrm{CA}$ arg & $0,05 \mathrm{~A}^{*}$ & $0,24 \mathrm{~A}^{*}$ \\
\hline $\mathrm{P} \arg _{2}$ & $0,22 \mathrm{~A} *$ & $0,06 \mathrm{~A}^{*}$ \\
\hline $\mathrm{CV}(\%)$ & 69,15 & 65,14 \\
\hline
\end{tabular}

Médias seguidas de mesma letra, na coluna, não diferem estatisticamente entre si pelo teste de Tukey a 5\% de probabilidade.

* As letras são referentes à comparação dos dados transformados para raiz quadrada.

$\mathrm{M}=$ Cultura da manga, $\mathrm{P}=$ Pastagem, $\mathrm{PA}=$ Pastagem, $\mathrm{PL}_{1}=$ Pastagem, $\mathrm{PL}_{2}=$ Pastagem, $\mathrm{CA}=$ cultura anual, $\mathrm{VD}$

= Vegetação degradada com pequenos fragmentos de área com vegetação nativa, $\mathrm{P} \arg _{1}=\mathrm{Pastagem}_{\mathrm{C}} \mathrm{CA} \arg =$ Cultura anual e $\mathrm{P} \arg _{2}=$ Pastagem.

Os valores de condutividade hidráulica do solo saturado variaram de 0,05 a $0,70 \mathrm{~cm} \mathrm{~h}^{-1}$ no Latossolo e de 0,05 a $0,22 \mathrm{~cm} \mathrm{~h}^{-1}$ no Argissolo para a profundidade de $10 \mathrm{~cm}$, e de 0,02 a $0,27 \mathrm{~cm} \mathrm{~h}^{-1}$ no Latossolo e de 0,06 a $0,25 \mathrm{~cm} \mathrm{~h}^{-1}$ no Argissolo para a profundidade de $20 \mathrm{~cm}$. Na profundidade de $10 \mathrm{~cm}$ o maior valor de condutividade hidráulica do solo saturado no Latossolo foi observado para a cultura anual (CA) seguido das pastagens ( $\mathrm{PL}_{2}$ e PA), e no Argissolo o maior valor observado foi para a pastagem ( $\mathrm{P} \arg _{2}$ ). Para a profundidade de $20 \mathrm{~cm}$ o maior valor de condutividade hidráulica do solo saturado no Latossolo foi observado para a pastagem $\left(\mathrm{PL}_{2}\right)$, e no Argissolo para a pastagem ( $\left.\mathrm{P} \arg _{1}\right)$, seguido da cultura anual (CA arg).

Para as profundidades de 10 e de $20 \mathrm{~cm}$ para todos os usos e em ambos os solos os valores de condutividade hidráulica do solo saturado foram considerados muito lentos. Com exceção para a cultura anual (CA) no Latossolo na profundidade de $10 \mathrm{~cm}$, o qual foi classificado como lento. 
Os valores de taxa constante de infiltração e de condutividade hidráulica do solo saturado, nas duas classes de solos, foram bem menores para as profundidades de $10 \mathrm{~cm}$ e de $20 \mathrm{~cm}$ quando comparados com os valores obtidos na superfície do solo, isso ocorreu devido à influência da cobertura vegetal. Aliado a isso, com o aumento da profundidade, há aumento dos conteúdos de argila e aumento nos valores de densidade do solo, contribuindo também para os menores valores observados para tais profundidades.

Quanto às propriedades físicas dos solos da Sub-Bacia estudada, podese observar que, o Argissolo apresentou maior microporosidade, porosidade total, armazenamento e retenção de água no solo quando comparado com o Latossolo. Quanto às variáveis DMP e macroporosidade, estes não apresentaram diferenças entre si independentemente da cobertura do solo, pois os valores destas propriedades estão próximos para ambos os solos.

Estes resultados indicam que para a maioria das variáveis dependentes das propriedades do solo, como a textura do solo, há diferenças destas quando se comparam as duas classes de solos. E que outras variáveis, como o DMP e a macroporosidade, as quais são dependentes da estrutura, e consequentemente da sua cobertura vegetal, os valores estão próximos para os dois solos.

No geral, as melhores condições físicas foram observadas no Argissolo, sendo a cultura anual (CA arg), o uso que apresentou os maiores valores de macroporosidade, microporosidade, porosidade total e retenção de água no solo, e menor valor de densidade do solo. Estas melhores condições são importantes, pois esta área apresentou o maior conteúdo de silte, de acordo com Lima e Andrade (2001), elevados teores de silte no solo favorecem o processo de erosão.

Apesar das áreas ocupadas com pastagens serem um dos usos mais indicados, estas se encontram em processo de degradação dos solos, sendo as propriedades macroporosidade, microporosidade, porosidade total e densidade do solo, as mais degradadas. Quanto ao solo cultivado com manga (M) e sob vegetação degradada (VD), estes também apresentaram baixos valores destas mesmas propriedades.

No que diz respeito à permeabilidade dos solos estudados, o Latossolo apresentou melhores valores de infiltração e de condutividade hidráulica, mesmo com algumas propriedades físicas degradadas, devido os Latossolos serem solos bastante permeáveis. 
Observa-se que as melhores condições de permeabilidade foram encontradas para as culturas anuais devido ao preparo do solo, seguido das pastagens devido aos maiores valores de DMP. O solo sob a cultura da manga (M) e sob vegetação degradada (VD) por apresentarem piores condições com relação à macroporosidade dos solos, consequentemente apresentaram menor permeabilidade quando comparados com os outros usos.

O que se deve ressaltar também é que nas áreas com culturas anuais, as quais apresentaram boas condições de permeabilidade, é devido o solo estar preparado no período de coleta de solos, e isso dá a impressão de uma área com boas condições de solo e de manejo, o que pode não ser uma verdade, pois estas áreas ficam em pousio durante algumas épocas do ano, devendo-se tomar cuidado com manejo das mesmas. Em locais com solos descobertos associados à degradação de algumas propriedades físicas há maior risco de erosão e degradação do solo.

Com relação às propriedades químicas dos solos sob diferentes usos e ocupações, nas Tabelas 13 e 14 encontram-se os valores médios das análises químicas para as camadas 0 a 10 e 10 a $20 \mathrm{~cm}$, respectivamente, sendo estes valores classificados de acordo com Raij et al. (2001). Para a camada de 0 a $10 \mathrm{~cm}$ no Latossolo, houve diferença significativa entre os usos e ocupações do solo para as variáveis $\mathrm{P}, \mathrm{Ca}^{+2}, \mathrm{Mg}^{+2}, \mathrm{SB}, \mathrm{CTC}, \mathrm{B}$, cobre, Mn e $\mathrm{Zn}$. No Argissolo houve diferença significativa para as variáveis $\mathrm{pH}, \mathrm{P}, \mathrm{B}$, cobre, Fe e Mn.

Os valores de $\mathrm{pH}$ variaram de 5,2 a 5,5 no Latossolo e de 5,1 a 6,0 no Argissolo, se enquadrando entre médio e alto, sendo alto para a cultura anual (CA arg) no Argissolo e médio para os demais usos e ocupações nas duas classes de solos. O maior valor encontrado para a cultura anual no Argissolo (CA $\arg$ ) provavelmente, é devido à correção do solo. No Latossolo o maior valor de pH também foi observado para a cultura anual (CA), que não diferenciou estatisticamente das pastagens. No Argissolo também foi observado este efeito, o que comprova que a correção do solo aumentou o pH nestes usos e ocupações, pois difere da vegetação degradada (VD) que apresentou o menor valor de $\mathrm{pH}$, pela ausência de correção nesta área. 
Tabela 13. Valores médios de $\mathrm{pH}, \mathrm{MO}, \mathrm{P}, \mathrm{K}^{+}, \mathrm{Ca}^{+2}, \mathrm{Mg}^{+2}, \mathrm{Al}^{+3}, \mathrm{H}+\mathrm{Al}, \mathrm{SB}, \mathrm{CTC}, \mathrm{V} \%$ e micronutrientes, para as duas classes de solos, sob diferentes formas de uso e de ocupação, na camada de 0 a $10 \mathrm{~cm}$.

\begin{tabular}{|c|c|c|c|c|c|c|c|c|}
\hline $\begin{array}{c}\text { Usos e } \\
\text { ocupações } \\
\text { dos solos }\end{array}$ & $\frac{\mathbf{p H}}{\mathrm{CaCl}_{2}}$ & $\frac{\text { MO }}{\mathrm{g} \mathrm{dm}^{-3}}$ & $\frac{\mathbf{P}}{\mathrm{mg} \mathrm{dm}^{-3}}$ & $\mathbf{K}^{+}$ & $\mathrm{Ca}^{+2}$ & $\frac{\mathbf{M g}^{\mathbf{+ 2}}}{\mathrm{mmol}_{\mathrm{c}} \mathrm{dm}^{-3}}$ & $\mathbf{A l}^{+3}$ & $\mathbf{H}+\mathbf{A l}$ \\
\hline \multicolumn{9}{|c|}{ Camada 0 a $10 \mathrm{~cm}$} \\
\hline \multicolumn{9}{|c|}{ Latossolo Vermelho distrófico } \\
\hline M & $5,3 \mathrm{~A}$ & $17 \mathrm{~A}^{*}$ & $13 \mathrm{~A}$ & $1,4 \mathrm{~A}^{*}$ & $27 \mathrm{AB}$ & $9 \mathrm{AB}$ & $1 \mathrm{~A}$ & $25 \mathrm{~A}$ \\
\hline $\mathrm{P}$ & $5,4 \mathrm{~A}$ & $18 \mathrm{~A}^{*}$ & $8 \mathrm{AB}$ & $1,3 \mathrm{~A} *$ & $24 \mathrm{AB}$ & $11 \mathrm{AB}$ & $1 \mathrm{~A}$ & $21 \mathrm{~A}$ \\
\hline PA & $5,3 \mathrm{~A}$ & $10 \mathrm{~A}^{*}$ & $6 \mathrm{~B}$ & $1,5 \mathrm{~A}^{*}$ & $18 \mathrm{~B}$ & $5 \mathrm{~B}$ & $1 \mathrm{~A}$ & $16 \mathrm{~A}$ \\
\hline $\mathrm{PL}_{1}$ & $5,2 \mathrm{~A}$ & $18 \mathrm{~A}^{*}$ & $7 \mathrm{~B}$ & $1,4 \mathrm{~A}^{*}$ & $18 \mathrm{~B}$ & $8 \mathrm{AB}$ & $1 \mathrm{~A}$ & $20 \mathrm{~A}$ \\
\hline $\mathrm{PL}_{2}$ & $5,4 \mathrm{~A}$ & $19 \mathrm{~A}^{*}$ & $7 \mathrm{~B}$ & $0,9 \mathrm{~A}^{*}$ & $33 \mathrm{AB}$ & $13 \mathrm{AB}$ & $1 \mathrm{~A}$ & $21 \mathrm{~A}$ \\
\hline CA & $5,5 \mathrm{~A}$ & $17 \mathrm{~A}^{*}$ & $12 \mathrm{~A}$ & $1,8 \mathrm{~A}^{*}$ & $43 \mathrm{~A}$ & $14 \mathrm{~A}$ & $1 \mathrm{~A}$ & $23 \mathrm{~A}$ \\
\hline $\mathrm{CV}(\%)$ & 5,35 & 23,86 & 27,93 & 28,79 & 38,91 & 39,58 & 24,21 & 21,68 \\
\hline \multicolumn{9}{|c|}{ Argissolo Vermelho-Amarelo eutrófico } \\
\hline VD & $5,2 \quad \mathrm{~B}$ & $21 \mathrm{~A}^{*}$ & $12 \mathrm{~B}$ & $1,5 \mathrm{~A}^{*}$ & $52 \mathrm{~A}^{*}$ & $18 \mathrm{~A}^{*}$ & $2 \mathrm{~A}^{*}$ & $28 \mathrm{~A}$ \\
\hline $\mathrm{P} \arg _{1}$ & $5,5 \mathrm{AB}$ & $27 \mathrm{~A}^{*}$ & $14 \mathrm{~B}$ & $2,4 \mathrm{~A} *$ & $99 \mathrm{~A}^{*}$ & $22 \mathrm{~A} *$ & $1 \mathrm{~A}^{*}$ & $27 \mathrm{~A}$ \\
\hline $\mathrm{CA}$ arg & $6,0 \mathrm{~A}$ & $33 \mathrm{~A}^{*}$ & $35 \mathrm{~A}$ & $2,7 \mathrm{~A}^{*}$ & $148 \mathrm{~A}^{*}$ & $38 \mathrm{~A}^{*}$ & $1 \mathrm{~A}^{*}$ & $27 \mathrm{~A}$ \\
\hline $\mathrm{P} \arg _{2}$ & $5,3 \mathrm{AB}$ & $20 \mathrm{~A}^{*}$ & $10 \mathrm{~B}$ & $1,0 \mathrm{~A} *$ & $49 \mathrm{~A}^{*}$ & $17 \mathrm{~A}^{*}$ & $1 \mathrm{~A}^{*}$ & $27 \mathrm{~A}$ \\
\hline \multirow[t]{3}{*}{$\mathrm{CV}(\%)$} & 8,07 & 19,04 & 48,93 & 43,16 & 45,09 & 33,38 & 30,84 & 16,61 \\
\hline & SB & CTC & $\mathbf{V}$ & B & $\mathbf{C u}$ & $\mathbf{F e}$ & Mn & $\mathbf{Z n}$ \\
\hline & \multicolumn{2}{|c|}{$\mathrm{mmol}_{\mathrm{c}} \mathrm{dm}^{-3}$} & $\%$ & & & $\mathrm{mg} \mathrm{dm}^{-3}$ & & \\
\hline \multicolumn{9}{|c|}{ Latossolo Vermelho distrófico } \\
\hline M & $37 \mathrm{AB}$ & $62 \mathrm{AB}$ & $60 \mathrm{~A}$ & $0,36 \mathrm{~A}$ & $1,1 \quad \mathrm{~B}^{*}$ & $51 \mathrm{~A}^{*}$ & $23,0 \quad \mathrm{~B} *$ & $1,7 \quad \mathrm{~B} *$ \\
\hline $\mathrm{P}$ & $36 \mathrm{AB}$ & $57 \mathrm{AB}$ & $63 \mathrm{~A}$ & $0,31 \mathrm{AB}$ & $1,2 \quad \mathrm{~B} *$ & $25 \mathrm{~A}^{*}$ & $33,2 \quad \mathrm{~B} *$ & $1,2 \quad \mathrm{~B} *$ \\
\hline PA & $25 \mathrm{~B}$ & $41 \mathrm{~B}$ & $59 \mathrm{~A}$ & 0,18 & $3,6 \mathrm{AB} *$ & $23 \mathrm{~A}^{*}$ & $32,5 \quad \mathrm{~B}^{*}$ & $3,1 \mathrm{AB} *$ \\
\hline $\mathrm{PL}_{1}$ & $28 \mathrm{~B}$ & $47 \mathrm{~B}$ & $59 \mathrm{~A}$ & $0,24 \mathrm{BC}$ & $1,6 \mathrm{~B}^{*}$ & $32 \mathrm{~A} *$ & $36,4 \quad \mathrm{~B}^{*}$ & $1,7 \quad \mathrm{~B} *$ \\
\hline $\mathrm{PL}_{2}$ & $46 \mathrm{AB}$ & $67 \mathrm{AB}$ & $68 \mathrm{~A}$ & $0,31 \mathrm{AB}$ & $1,5 \quad \mathrm{~B}^{*}$ & $31 \mathrm{~A}^{*}$ & $31,5 \quad \mathrm{~B}^{*}$ & $1,8 \quad \mathrm{~B}^{*}$ \\
\hline $\mathrm{CA}$ & $59 \mathrm{~A}$ & $82 \mathrm{~A}$ & $70 \mathrm{~A}$ & $0,28 \mathrm{AB}$ & $14,6 \mathrm{~A}^{*}$ & $33 \mathrm{~A} *$ & $85,8 \mathrm{~A}^{*}$ & $4,9 \mathrm{~A}^{*}$ \\
\hline $\mathrm{CV}(\%)$ & 37,20 & 28,22 & 10,94 & 16,72 & 49,05 & 23,67 & 22,83 & 27,24 \\
\hline \multicolumn{9}{|c|}{ Argissolo Vermelho-Amarelo eutrófico } \\
\hline VD & $72 \mathrm{~A}^{*}$ & $100 \mathrm{~A}^{*}$ & $63 \mathrm{~A}$ & $0,32 \quad \mathrm{~B}$ & $5,36 \mathrm{~B} *$ & $\mathrm{~B} *$ & $44,3 \mathrm{AB}^{*}$ & $3,3 \mathrm{~A}^{*}$ \\
\hline $\mathrm{P} \arg _{1}$ & $123 \mathrm{~A}^{*}$ & $149 \mathrm{~A}^{*}$ & $73 \mathrm{~A}$ & $0,33 \mathrm{~B}$ & $9,3 \quad \mathrm{AB}^{*}$ & $60 \mathrm{AB}^{*}$ & $29,5 \quad B *$ & $3,8 \mathrm{~A}^{*}$ \\
\hline $\mathrm{CA}$ arg & $189 \mathrm{~A}^{*}$ & $215 \mathrm{~A}^{*}$ & $83 \mathrm{~A}$ & $0,48 \mathrm{~A}$ & $15,5 \mathrm{~A}^{*}$ & $32 \quad \mathrm{~B} *$ & $65,2 \mathrm{~A}^{*}$ & $4,1 \mathrm{~A}^{*}$ \\
\hline $\mathrm{P} \arg _{2}$ & $67 \mathrm{~A}^{*}$ & $93 \mathrm{~A}^{*}$ & $66 \mathrm{~A}$ & $0,30 \quad \mathrm{~B}$ & $6,4 \quad \mathrm{~B} *$ & $102 \mathrm{~A}^{*}$ & $31,5 \quad \mathrm{~B} *$ & $2,8 \mathrm{~A}^{*}$ \\
\hline $\mathrm{CV}(\%)$ & 41,52 & 31,47 & 23,05 & 19,07 & 31,43 & 27,18 & 20,41 & 26,93 \\
\hline
\end{tabular}

Médias seguidas de mesma letra, na coluna, não diferem estatisticamente entre si pelo teste de Tukey a 5\% de probabilidade.

* As letras são referentes à comparação dos dados transformados para raiz quadrada.

$\mathrm{M}=$ Cultura da manga, $\mathrm{P}=$ Pastagem, $\mathrm{PA}=$ Pastagem, $\mathrm{PL}_{1}=$ Pastagem, $\mathrm{PL}_{2}=$ Pastagem, $\mathrm{CA}=$ cultura anual, $\mathrm{VD}$ = Vegetação degradada com pequenos fragmentos de área com vegetação nativa, $\mathrm{P} \arg _{1}=\mathrm{Pastagem}_{\mathrm{C}} \mathrm{CA} \arg =$ Cultura anual e $\mathrm{P} \arg _{2}=$ Pastagem.

O uso e o manejo do solo são fatores que interferem no conteúdo de matéria orgânica do solo. A matéria orgânica (MO) variou de 10 a $19 \mathrm{~g} \mathrm{dm}^{-3}$ no Latossolo e de 20 a $33 \mathrm{~g} \mathrm{dm}^{-3}$ no Argissolo. Comparando-se as duas classes de solos, observa-se que os maiores conteúdos de matéria orgânica foram observados para o Argissolo, sendo o maior 
conteúdo encontrado para a cultura anual (CA arg), isto ocorreu provavelmente devido ao maior conteúdo de argila, pois geralmente, solos argilosos tendem a apresentar maiores conteúdos de matéria orgânica.

Observa-se uma relação entre o conteúdo de matéria orgânica e a densidade do solo, nos usos com maiores conteúdos de matéria orgânica verifica-se menores valores de densidade do solo, pois a densidade do solo aumenta com a diminuição do conteúdo de matéria orgânica. A matéria orgânica influi na agregação do solo, melhorando a sua estrutura e consequentemente a sua porosidade, diminuindo assim, a sua densidade.

$\mathrm{O}$ conteúdo de fósforo (P) nos solos variou de 6 a $13 \mathrm{mg} \mathrm{dm}^{-3}$ no Latossolo e de 10 a $35 \mathrm{mg} \mathrm{dm}^{-3}$ no Argissolo, sendo alto para a vegetação degradada (VD) no Argissolo, médio para a cultura da manga (M) no Latossolo, para a pastagem ( $\left.\mathrm{P} \arg _{1}\right)$ e para a cultura anual (CA arg) no Argissolo, e baixo para os demais usos e ocupações. No Latossolo o maior conteúdo de fósforo foi observado para a cultura anual (CA) e o menor para a pastagem (PA). No Argissolo também foi observado comportamento semelhante, sendo o maior conteúdo encontrado para a cultura anual (CA $\arg )$ e o menor valor para a pastagem $(\mathrm{P} \arg 2)$.

Observa-se para as duas classes de solos que os menores conteúdos de fósforo (P) foram encontrados para as pastagens, isso pode ser devido à ausência de adubação quando comparado com a cultura anual. Estes resultados concordam com os obtidos por Centurion et al. (2001) que também observaram os menores teores de fósforo para a pastagem.

Quanto às bases trocáveis, o conteúdo de potássio $\left(\mathrm{K}^{+}\right)$variou de 0,9 a $1,8 \mathrm{mmol}_{\mathrm{c}} \mathrm{dm}^{-3}$ para o Latossolo e de 1,0 a 2,7 $\mathrm{mmol}_{\mathrm{c}} \mathrm{dm}^{-3}$ para o Argissolo, sendo médio para as culturas anuais (CA e CA $\arg$ ) nas duas classes de solos e para a pastagem $\left(\mathrm{P} \arg { }_{1}\right)$ no Argissolo, e baixo para os demais usos e ocupações. Para o conteúdo de cálcio $\left(\mathrm{Ca}^{+2}\right)$, estes foram altos para todos os usos e ocupações nas duas classes de solos, variando de 18 a 43 $\mathrm{mmol}_{\mathrm{c}} \mathrm{dm}^{-3}$ no Latossolo e de 49 a $148 \mathrm{mmol}_{\mathrm{c}} \mathrm{dm}^{-3}$ no Argissolo. E os de magnésio $\left(\mathrm{Mg}^{+2}\right)$ variaram entre 5 e $14 \mathrm{mmol}_{\mathrm{c}} \mathrm{dm}^{-3}$ para o Latossolo e entre 17 e $38 \mathrm{mmol}_{\mathrm{c}} \mathrm{dm}^{-3}$ para o Argissolo, estes foram médios para as pastagens ( $\mathrm{PA}$ e $\left.\mathrm{PL}_{1}\right)$ no Latossolo e alto para os demais

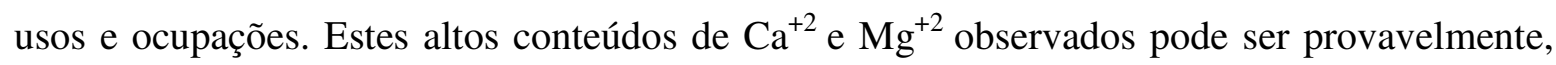
devido à aplicação de calcário, Queiroz (2008) avaliando os solos desta Sub-Bacia, também

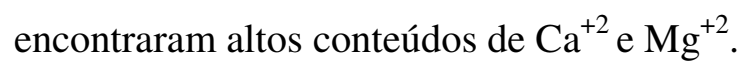


Observa-se que os maiores conteúdos observados para todas as bases trocáveis foram para as culturas anuais nas duas classes de solo. Os menores conteúdos de bases trocáveis foram observados para o Latossolo, sendo o menor valor de $\mathrm{K}^{+}$encontrado para a pastagem $\left(\mathrm{PL}_{2}\right)$, o de $\mathrm{Ca}^{+2}$ para as pastagens $\left(\mathrm{PA}\right.$ e $\left.\mathrm{PL}_{1}\right)$, e o de $\mathrm{Mg}^{+2}$ para a pastagem (PA). Como observado para o fósforo (P), as bases também apresentaram os menores conteúdos para as pastagens nas duas classes de solos, evidenciando mais uma vez a ausência de adubação quando comparado às culturas anuais.

Os valores de alumínio $\left(\mathrm{Al}^{+3}\right)$ não apresentaram diferenças significativas, estes foram $1 \mathrm{mmol}_{\mathrm{c}} \mathrm{dm}^{-3}$ para todos os usos nas duas classes de solos, com exceção a vegetação degradada (VD) no Argissolo, que apresentou o maior valor observado com $2 \mathrm{mmol}_{\mathrm{c}} \mathrm{dm}^{-3}$, Carneiro et al. (2009) também encontraram maiores teores de $\mathrm{Al}^{+3}$ para áreas não manejadas.

Com relação à acidez potencial $(\mathrm{H}+\mathrm{Al})$, os valores variaram de $16 \mathrm{a}$ $25 \mathrm{mmol}_{\mathrm{c}} \mathrm{dm}^{-3}$ no Latossolo e de 27 a $28 \mathrm{mmol}_{\mathrm{c}} \mathrm{dm}^{-3}$ no Argissolo. No Latossolo o maior valor foi observado para a cultura da manga (M). E no Argissolo o maior valor foi encontrado para a vegetação degradada (VD), concordando com os resultados obtidos por Carneiro et al. (2009), não diferenciando estatisticamente dos demais usos no Argissolo ( $\mathrm{P} \arg _{1}$, CA $\arg$ e P $\left.\arg _{2}\right)$.

Os valores de soma de bases (SB) variaram de 25 a $59 \mathrm{mmol}_{\mathrm{c}} \mathrm{dm}^{-3}$ no Latossolo e de 67 a $189 \mathrm{mmol}_{\mathrm{c}} \mathrm{dm}^{-3}$ no Argissolo, a capacidade de troca catiônica (CTC) variou de 41 a $82 \mathrm{mmol}_{\mathrm{c}} \mathrm{dm}^{-3}$ no Latossolo e de 93 a $215 \mathrm{mmol}_{\mathrm{c}} \mathrm{dm}^{-3}$ no Argissolo, e a saturação por bases (V\%) variou de 59 a 70\% no Latossolo e de 63 a $83 \%$ no Argissolo. Para estas variáveis os maiores valores encontrados foram para as culturas anuais nas duas classes de solos. No Latossolo os menores valores foram observados para a pastagem (PA), refletindo os teores das bases.

Os valores de saturação por bases (V\%) não diferiram estatisticamente entre si nas duas classes de solos, sendo alto para a cultura anual (CA arg) no Argissolo e médio para os demais usos e ocupações nas duas classes de solos. Verifica-se que os valores de saturação por bases foram maiores para o Argissolo, devido ao fato deste ser um solo naturalmente eutrófico. 
Quanto aos valores de CTC, pode-se afirmar que estes refletiram os conteúdos de matéria orgânica no solo. Pode-se verificar também que, o Argissolo apresentou os maiores valores de CTC, devido além dos maiores conteúdos de matéria orgânica no solo, aos maiores conteúdos de argila presente neste solo.

Para os micronutrientes, os conteúdos variaram de 0,18 a $0,36 \mathrm{mg} \mathrm{dm}^{-3}$ no Latossolo e de 0,30 a $0,48 \mathrm{mg} \mathrm{dm}^{-3}$ no Argissolo para o boro (B), o qual apresentou conteúdos baixos para a pastagem (PA) no Latossolo e médio para os demais usos e ocupações. Os conteúdos de cobre $(\mathrm{Cu})$, ferro $(\mathrm{Fe})$, manganês $(\mathrm{Mn})$ e zinco $(\mathrm{Zn})$ foram altos para todos os usos nas duas classes de solos, variando de 1,1 a 14,6 $\mathrm{mg} \mathrm{dm}^{-3}$ no Latossolo e de 5,36 a 15,5 $\mathrm{mg} \mathrm{dm}^{-3}$ no Argissolo para o cobre $(\mathrm{Cu})$, de 23 a $51 \mathrm{mg} \mathrm{dm}^{-3}$ no Latossolo e de 32 a $102 \mathrm{mg} \mathrm{dm}^{-3}$ no Argissolo para o ferro (Fe), de 23 a 85,8 $\mathrm{mg} \mathrm{dm}^{-3}$ no Latossolo e de 29,5 a $65,2 \mathrm{mg} \mathrm{dm}^{-3}$ no Argissolo para manganês (Mn) e de 1,2 a 4,9 $\mathrm{mg} \mathrm{dm}^{-3}$ no Latossolo e de 2,8 a $4,1 \mathrm{mg} \mathrm{dm}^{-3}$ no Argissolo para zinco (Zn).

Para o B o maior conteúdo encontrado no Latossolo foi para a cultura da manga (M) e no Argissolo foi para a cultura anual (CA arg), sendo os menores valores observados para a pastagem (PA) no Latossolo e para a pastagem ( $\left.\mathrm{P} \arg _{2}\right)$ no Argissolo. Para o cobre os maiores conteúdos foram encontrados para as culturas anuais nas duas classes de solos, e o menor valor para a cultura da manga (M) no Latossolo e para a vegetação degradada (VD) no Argissolo. Para o Fe o maior conteúdo encontrado no Latossolo foi para a cultura da manga (M) e no Argissolo para a pastagem ( $\left.\mathrm{P} \arg _{2}\right)$, já o menor valor foi observado para a pastagem (PA) no Latossolo e para a cultura anual (CA arg) no Argissolo. Para Mn e Zn no Latossolo o maior conteúdo observado foi para a cultura anual (CA), e os menores conteúdos destes, foram encontrados para a cultura da manga (M) e para a pastagem (P), respectivamente. No Argissolo também foram observados maiores conteúdos destes para a cultura anual (CA arg), sendo os menores valores de Mn para a pastagem ( $\left.\mathrm{P} \arg _{1}\right)$ e de $\mathrm{Zn}$ para a pastagem $\left(\mathrm{P} \arg _{2}\right)$.

Para a camada de 10 a $20 \mathrm{~cm}$, no Latossolo, houve diferença significativa entre os usos e ocupações do solo para as variáveis $\mathrm{pH}, \mathrm{P}, \mathrm{Ca}^{+2}, \mathrm{Mg}^{+2}, \mathrm{SB}, \mathrm{CTC}$, $\mathrm{V} \%$ e para os micronutrientes. No Argissolo houve diferença para as variáveis $\mathrm{pH}, \mathrm{Ca}^{+2}, \mathrm{Mg}^{+2}$, SB, CTC, V\%, B e cobre (Tabela 14). 
Tabela 14. Valores médios de $\mathrm{pH}, \mathrm{MO}, \mathrm{P}, \mathrm{K}^{+}, \mathrm{Ca}^{+2}, \mathrm{Mg}^{+2}, \mathrm{Al}^{+3}, \mathrm{H}+\mathrm{Al}, \mathrm{SB}, \mathrm{CTC}, \mathrm{V} \%$ e micronutrientes, para as duas classes de solos, sob diferentes formas de uso e de ocupação, na camada de 10 a $20 \mathrm{~cm}$.

\begin{tabular}{|c|c|c|c|c|c|c|c|c|}
\hline $\begin{array}{c}\text { Usos e } \\
\text { ocupações } \\
\text { dos solos }\end{array}$ & $\frac{\mathbf{p H}}{\mathrm{CaCl}_{2}}$ & $\frac{\text { MO }}{\mathrm{g} \mathrm{dm}^{-3}}$ & $\frac{\mathbf{P}}{\mathrm{mg} \mathrm{dm}}$ & $\mathbf{K}^{+}$ & $\mathbf{C a}^{+2}$ & $\frac{\mathbf{M g}^{+2}}{\mathrm{mmol}_{\mathrm{c}} \mathrm{dm}^{-}}$ & $\mathbf{A l}^{+3}$ & $\mathbf{H}+\mathbf{A l}$ \\
\hline \multicolumn{9}{|c|}{ Camada 10 a $20 \mathrm{~cm}$} \\
\hline \multicolumn{9}{|c|}{ Latossolo Vermelho distrófico } \\
\hline M & $4,7 \quad \mathrm{~B}$ & $11 \mathrm{~A}$ & $8 \mathrm{AB}$ & $0,8 \mathrm{~A}^{*}$ & $20 \mathrm{~B}$ & $7 \mathrm{AB}$ & $2 \mathrm{~A}$ & $35 \mathrm{~A}$ \\
\hline $\mathrm{P}$ & $5,4 \mathrm{~A}$ & $10 \mathrm{~A}$ & $7 \mathrm{AB}$ & $1,0 \mathrm{~A}^{*}$ & $22 \mathrm{~B}$ & $7 \mathrm{AB}$ & $1 \mathrm{~A}$ & $19 \mathrm{~B}$ \\
\hline PA & $5,4 \mathrm{~A}$ & $8 \mathrm{~A}$ & $7 \mathrm{AB}$ & $0,9 \mathrm{~A}^{*}$ & $23 \mathrm{~B}$ & $4 \mathrm{~B}$ & $1 \mathrm{~A}$ & $15 \mathrm{~B}$ \\
\hline $\mathrm{PL}_{1}$ & 5,4 A & $8 \mathrm{~A}$ & $6 \mathrm{~B}$ & $1,5 \mathrm{~A}^{*}$ & $19 \mathrm{~B}$ & $8 \mathrm{AB}$ & $1 \mathrm{~A}$ & $15 \mathrm{~B}$ \\
\hline $\mathrm{PL}_{2}$ & $5,4 \mathrm{~A}$ & $13 \mathrm{~A}$ & $6 \mathrm{~B}$ & $0,7 \mathrm{~A}^{*}$ & $30 \mathrm{AB}$ & $9 \mathrm{AB}$ & $1 \mathrm{~A}$ & $19 \mathrm{~B}$ \\
\hline $\mathrm{CA}$ & $5,6 \mathrm{~A}$ & $10 \mathrm{~A}$ & $10 \mathrm{~A}$ & $1,0 \mathrm{~A}^{*}$ & $43 \mathrm{~A}$ & $12 \mathrm{~A}$ & $1 \mathrm{~A}$ & $19 \mathrm{~B}$ \\
\hline $\mathrm{CV}(\%)$ & 5,24 & 34,02 & 27,91 & 35,13 & 31,07 & 41,43 & 23,47 & 15,85 \\
\hline \multicolumn{9}{|c|}{ Argissolo Vermelho-Amarelo eutrófico } \\
\hline VD & $5,2 \quad \mathrm{~B}$ & $14 \mathrm{~A} *$ & $14 \mathrm{~A}^{*}$ & $1,1 \mathrm{~A}^{*}$ & $49 \mathrm{~B}^{*}$ & $15 \mathrm{~B}^{*}$ & $2 \mathrm{~A}^{*}$ & $25 \mathrm{~A}$ \\
\hline $\mathrm{P} \arg _{1}$ & $5,5 \mathrm{AB}$ & $22 \mathrm{~A} *$ & $11 \mathrm{~A}^{*}$ & $1,2 \mathrm{~A}^{*}$ & $92 \mathrm{AB}^{*}$ & $22 \mathrm{AB}^{*}$ & $1 \mathrm{~A}^{*}$ & $24 \mathrm{~A}$ \\
\hline CA arg & $6,1 \mathrm{~A}$ & $25 \mathrm{~A}^{*}$ & $18 \mathrm{~A}^{*}$ & $1,7 \mathrm{~A}^{*}$ & $185 \mathrm{~A}^{*}$ & $45 \mathrm{~A}^{*}$ & $1 \mathrm{~A}^{*}$ & $24 \mathrm{~A}$ \\
\hline $\mathrm{P} \arg _{2}$ & $5,8 \mathrm{AB}$ & $18 \mathrm{~A}^{*}$ & $8 \mathrm{~A}^{*}$ & $0,4 \mathrm{~A}^{*}$ & $77 \quad \mathrm{~B}^{*}$ & $26 \mathrm{AB}^{*}$ & $1 \mathrm{~A}^{*}$ & $21 \mathrm{~A}$ \\
\hline $\mathrm{CV}(\%)$ & 8,57 & 28,29 & 27,48 & 50,65 & 35,12 & 32,23 & 25,84 & 23,76 \\
\hline \multirow{2}{*}{\multicolumn{3}{|c|}{$\mathrm{mmol}_{\mathrm{c}} \mathrm{dm}^{-3}$}} & $\mathbf{V}$ & B & $\mathbf{C u}$ & $\mathbf{F e}$ & Mn & Zn \\
\hline & & & $\%$ & & & $\mathrm{mg} \mathrm{dm}^{-3}$ & & \\
\hline \multicolumn{9}{|c|}{ Latossolo Vermelho distrófico } \\
\hline M & $28 \quad \mathrm{~B}$ & $63 \mathrm{AB}$ & $45 \quad \mathrm{~B}$ & $0,33 \mathrm{~A}$ & $1,2 \quad \mathrm{~B}^{*}$ & $32 \mathrm{~A}$ & $18,6 \quad$ B & $0,8 \quad \mathrm{BC}^{*}$ \\
\hline $\mathrm{P}$ & $31 \mathrm{~B}$ & $49 \quad \mathrm{~B}$ & $62 \mathrm{~A}$ & $0,29 \mathrm{AB}$ & $1,3 \quad \mathrm{~B}^{*}$ & $15 \mathrm{~B}$ & $33,4 \mathrm{AB}$ & $0,4 \quad C^{*}$ \\
\hline PA & $27 \quad \mathrm{~B}$ & $43 \mathrm{~B}$ & $62 \mathrm{~A}$ & $0,19 \quad \mathrm{C}$ & $4,6 \mathrm{AB}^{*}$ & $19 \mathrm{~B}$ & $36,3 \mathrm{AB}$ & $2,4 \mathrm{AB}^{*}$ \\
\hline $\mathrm{PL}_{1}$ & 29 B & $44 \quad \mathrm{~B}$ & $65 \mathrm{~A}$ & $0,21 \quad \mathrm{BC}$ & $1,4 \quad \mathrm{~B}^{*}$ & $17 \mathrm{~B}$ & $27,4 \quad$ B & $0,7 \quad B C^{*}$ \\
\hline $\mathrm{PL}_{2}$ & $40 \mathrm{AB}$ & $59 \mathrm{AB}$ & $68 \mathrm{~A}$ & $0,29 \mathrm{AB}$ & $1,4 \quad \mathrm{~B}^{*}$ & $20 \quad \mathrm{~B}$ & 26,9 B & $0,9 \mathrm{ABC}^{*}$ \\
\hline $\mathrm{CA}$ & $56 \mathrm{~A}$ & $75 \mathrm{~A}$ & $74 \mathrm{~A}$ & $0,27 \mathrm{ABC}$ & $11,9 \mathrm{~A}$ & $24 \mathrm{AB}$ & $63,6 \mathrm{~A}$ & 2,9 A* \\
\hline $\mathrm{CV}(\%)$ & 31,21 & 22,13 & 11,16 & 18,09 & 42,90 & 23,35 & 47,26 & 35,71 \\
\hline \multicolumn{9}{|c|}{ Argissolo Vermelho-Amarelo eutrófico } \\
\hline VD & $65 \mathrm{~B}^{*}$ & 89 B & $65 \mathrm{~B}$ & $0,28 \quad \mathrm{~B}$ & $5,9 \quad \mathrm{~B}^{*}$ & $23 \mathrm{~A}$ & $41,7 \mathrm{~A}$ & $2,7 \mathrm{~A}^{*}$ \\
\hline $\mathrm{P} \arg _{1}$ & $115 \mathrm{AB}^{*}$ & $138 \mathrm{AB}$ & $74 \mathrm{AB}$ & $0,32 \mathrm{AB}$ & $10,1 \mathrm{AB}^{*}$ & $49 \mathrm{~A}$ & $29,8 \mathrm{~A}$ & $2,2 \mathrm{~A}^{*}$ \\
\hline CA arg & $231 \mathrm{~A}^{*}$ & $256 \mathrm{~A}$ & $90 \mathrm{~A}$ & $0,40 \mathrm{~A}$ & $17,3 \mathrm{~A}^{*}$ & $32 \mathrm{~A}$ & $65,4 \mathrm{~A}$ & $2,4 \mathrm{~A}^{*}$ \\
\hline $\mathrm{P} \arg _{2}$ & $105 \mathrm{AB}^{*}$ & $125 \mathrm{AB}$ & $80 \mathrm{AB}$ & $0,26 \quad \mathrm{~B}$ & 7,9 $\mathrm{AB}^{*}$ & $34 \mathrm{~A}$ & $29,5 \mathrm{~A}$ & $1,1 \mathrm{~A}^{*}$ \\
\hline $\mathrm{CV}(\%)$ & 33,30 & 48,02 & 16,75 & 20,86 & 32,31 & 46,46 & 47,91 & 34,37 \\
\hline
\end{tabular}

Médias seguidas de mesma letra, na coluna, não diferem estatisticamente entre si pelo teste de Tukey a 5\% de probabilidade.

* As letras são referentes à comparação dos dados transformados para raiz quadrada.

$\mathrm{M}=$ Cultura da manga, $\mathrm{P}=$ Pastagem, $\mathrm{PA}=$ Pastagem, $\mathrm{PL}_{1}=$ Pastagem, $\mathrm{PL}_{2}=$ Pastagem, $\mathrm{CA}=$ cultura anual, $\mathrm{VD}$ $=$ Vegetação degradada com pequenos fragmentos de área com vegetação nativa, $\mathrm{P} \arg _{1}=$ Pastagem, $\mathrm{CA} \arg =$ Cultura anual e $\mathrm{P} \arg _{2}=$ Pastagem .

Os valores de pH variaram de 4,7 a 5,6 no Latossolo e de 5,2 a 6,1 no Argissolo, sendo baixo para a cultura da manga (M) no Latossolo, médio para as pastagens (P, $\left.\mathrm{PA}, \mathrm{PL}_{1}, \mathrm{PL}_{2}\right)$ no Latossolo e para a pastagem ( $\left.\mathrm{P} \arg _{1}\right)$ e a vegetação degradada (VD) no Argissolo, alto para a cultura anual (CA) no Latossolo e para a pastagem $\left(\mathrm{P} \arg _{2}\right)$ no 
Argissolo, e muito alto para a cultura anual (CA arg) no Argissolo. Assim como na camada superficial, os maiores valores encontrados foram para as culturas anuais nas duas classes de solos, e estas não diferiram das pastagens. $\mathrm{O}$ menor valor de $\mathrm{pH}$ encontrado foi para o solo cultivado com manga (M) no Latossolo e com vegetação degradada (VD) no Argissolo.

A matéria orgânica (MO) variou de 8 a $13 \mathrm{~g} \mathrm{dm}^{-3}$ no Latossolo e de 14 a $25 \mathrm{~g} \mathrm{dm}^{-3}$ no Argissolo, apresentando conteúdos mais baixos que na camada superficial, normalmente com o aumento da profundidade há diminuição do conteúdo de matéria orgânica devido à cobertura vegetal sobre o solo. Assim como na camada superficial, os maiores conteúdos foram encontrados para o Argissolo, sendo o maior conteúdo observado para a cultura anual (CA arg).

Os conteúdos de fósforo $(\mathrm{P})$ nos solos variaram de 6 a $10 \mathrm{mg} \mathrm{dm}^{-3}$ no Latossolo e de 8 a $18 \mathrm{mg} \mathrm{dm}^{-3}$ no Argissolo, estes foram alto para a vegetação degradada (VD) no Argissolo, médio para a cultura anual ( $\mathrm{CA}$ arg) no Argissolo e baixo para os demais usos e ocupações. Observa-se que os conteúdos para esta camada decresceram em relação à camada superficial, o que comprova a baixa mobilidade do P. De modo semelhante à camada superficial, os maiores conteúdos foram encontrados para as culturas anuais nas duas classes de solo.

Com relação às bases trocáveis, os conteúdos de potássio $\left(\mathrm{K}^{+}\right)$ variaram de 0,7 a 1,5 $\mathrm{mmol}_{\mathrm{c}} \mathrm{dm}^{-3}$ no Latossolo e de 0,4 a $1,7 \mathrm{mmol}_{\mathrm{c}} \mathrm{dm}^{-3}$ no Argissolo, sendo muito baixo para as pastagens $\left(\mathrm{PL}_{2}\right)$ no Latossolo e $\left(\mathrm{P} \arg _{2}\right)$ no Argissolo, baixo para a cultura da manga (M) no Latossolo, para as pastagens ( $\left.\mathrm{P}, \mathrm{PA}, \mathrm{PL}_{1}\right)$ no Latossolo e $\left(\mathrm{P} \arg { }_{1}\right)$ no Argissolo, para a cultura anual (CA) no Latossolo e para a vegetação degradada (VD) no Argissolo, e médio para a cultura anual (CA arg) no Argissolo. Os conteúdos de cálcio $\left(\mathrm{Ca}^{+2}\right)$ variaram de 19 a $43 \mathrm{mmol}_{\mathrm{c}} \mathrm{dm}^{-3}$ no Latossolo e de 49 e $185 \mathrm{mmol}_{\mathrm{c}} \mathrm{dm}^{-3}$ no Argissolo, o qual foram altos para todos os usos e ocupações nas duas classes de solos. Quanto aos conteúdos de magnésio $\left(\mathrm{Mg}^{+2}\right)$ que variaram de 4 a $12 \mathrm{mmol}_{\mathrm{c}} \mathrm{dm}^{-3}$ no Latossolo e de 15 a $45 \mathrm{mmol}_{\mathrm{c}} \mathrm{dm}^{-3}$ no Argissolo, foram baixo para a pastagem (PA) no Latossolo, médio para a cultura da manga (M) e para as pastagens ( $\mathrm{P}$ e $\mathrm{PL}_{1}$ ) no Latossolo, e alto para os demais usos e ocupações do solo.

Para o Latossolo o maior conteúdo de $\mathrm{K}^{+}$foi para a pastagem $\left(\mathrm{PL}_{1}\right)$ e de $\mathrm{Ca}^{+2}$ e $\mathrm{Mg}^{+2}$ para a cultura anual (CA). No Argissolo o maior conteúdo observado para 
todas as bases trocáveis foi para a cultura anual (CA $\arg$ ), sendo o menor conteúdo de $\mathrm{K}^{+}$

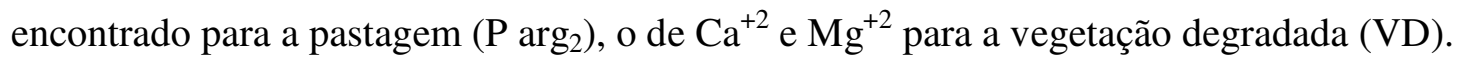

Os valores de alumínio $\mathrm{Al}^{+3}$ seguiram a tendência da camada superficial, sendo o maior valor observado para a vegetação degradada (VD) no Argissolo. Quanto ao $\mathrm{H}+\mathrm{Al}$, estes variaram de 15 a $35 \mathrm{mmol}_{\mathrm{c}} \mathrm{dm}^{-3}$ no Latossolo e de 21 a $25 \mathrm{mmol}_{\mathrm{c}} \mathrm{dm}^{-}$ ${ }^{3}$ no Argissolo, sendo no Latossolo o maior valor encontrado para a cultura da manga (M), e o menor para as pastagens ( $\mathrm{PA}$ e $\left.\mathrm{PL}_{1}\right)$, e no Argissolo o maior valor observado para a vegetação degradada (VD), e o menor para a pastagem ( $\left.\mathrm{P} \arg _{2}\right)$.

Os valores de soma de bases $(\mathrm{SB})$ variaram de 27 a $56 \mathrm{mmol}_{\mathrm{c}} \mathrm{dm}^{-3}$ no Latossolo e de 65 a $231 \mathrm{mmol}_{\mathrm{c}} \mathrm{dm}^{-3}$ no Argissolo, e a capacidade de troca catiônica (CTC) variou de 43 a $75 \mathrm{mmol}_{\mathrm{c}} \mathrm{dm}^{-3}$ no Latossolo e de 89 a $256 \mathrm{mmol}_{\mathrm{c}} \mathrm{dm}^{-3}$ no Argissolo. Para a CTC os valores se apresentaram de forma semelhante à camada superficial. A saturação por bases (V\%) variou de 45 a 74\% no Latossolo e de 65 a 90\% no Argissolo, sendo baixo para a cultura da manga (M) no Latossolo, médio para as pastagens ( $\mathrm{P}, \mathrm{PA}, \mathrm{PL}_{1}$ e $\mathrm{PL}_{2}$ ) no Latossolo e para a vegetação degradada (VD) no Argissolo, e alto para as culturas anuais (CA e CA arg) nas duas classes de solos, e para as pastagens no Argissolo ( $\mathrm{P} \arg _{1}$ e $\mathrm{P} \arg _{2}$ ).

Para as variáveis $\mathrm{SB}, \mathrm{CTC}$ e $\mathrm{V} \%$, os maiores valores encontrados foram para as culturas anuais nas duas classes de solos. No Latossolo os menores valores de SB e CTC foram para a pastagem (PA), assim como na camada superficial, estes valores refletem os teores das bases, e para o V\% o menor valor observado foi para a cultura da manga (M). No Argissolo os menores valores de SB, CTC e V\% foram observados para a vegetação degradada (VD).

Quanto aos micronutrientes, os conteúdos variaram de 0,19 a 0,33 mg $\mathrm{dm}^{-3}$ para o Latossolo e de 0,26 a 0,40 $\mathrm{mg} \mathrm{dm}^{-3}$ no Argissolo para boro (B), sendo baixo para a pastagem (PA) no Latossolo e médio para os demais usos e ocupações. De 1,2 a 11,9 $\mathrm{mg} \mathrm{dm}^{-3}$ no Latossolo e de 5,9 a $17,3 \mathrm{mg} \mathrm{dm}^{-3}$ no Argissolo para cobre $(\mathrm{Cu})$, de 15 a $32 \mathrm{mg} \mathrm{dm}^{-3}$ no Latossolo e de 23 a $49 \mathrm{mg} \mathrm{dm}^{-3}$ no Argissolo para ferro (Fe), e de 18,6 a 63,6 mg dm $\mathrm{mo}^{-3}$ Latossolo e de 29,5 a 65,4 $\mathrm{mg} \mathrm{dm}^{-3}$ no Argissolo para manganês (Mn), os quais apresentaram conteúdos altos para todos os usos e ocupações nas duas classes de solos. E de 0,4 a 2,9 mg $\mathrm{dm}^{-3}$ no Latossolo e de 1,1 a $2,7 \mathrm{mg} \mathrm{dm}^{-3}$ no Argissolo para zinco ( $\mathrm{Zn}$ ), sendo baixo para a 
pastagem (P) no Latossolo, médio para a cultura da manga $(\mathrm{M})$ e para as pastagens $\left(\mathrm{PL}_{1}, \mathrm{PL}_{2}\right)$ no Latossolo e a pastagem ( $\left.\mathrm{P} \arg _{2}\right)$ no Argissolo, e alto para os demais usos e ocupações.

No geral, os maiores conteúdos foram atribuídos para as culturas anuais e os menores para as pastagens nas duas classes de solos. Com isso observa-se que esses menores valores encontrados para as pastagens são reflexos de manejo inadequado das pastagens quanto à adubação. A pastagem (PA) no Latossolo apresentou o menor teor de bases e consequentemente à menor saturação por bases, o que pode ser atribuído à baixa CTC neste uso do solo, reflexo do baixo conteúdo de matéria orgânica encontrada, além disso, trata-se de um solo com alto conteúdo de areia, o que pode ter contribuído para tais características.

A vegetação degradada (VD) no Argissolo apresentou o menor valor de $\mathrm{pH}$, e os maiores teores de $\mathrm{Al}^{+3}$ e $\mathrm{H}+\mathrm{Al}$, provavelmente devido à ausência de adubação nesta área, estes resultados concordam com os obtidos por Carneiro et al. (2009), que também encontraram maiores teores destes quando comparados às áreas manejadas. Por outro lado, o conteúdo de matéria orgânica, fósforo (P) e as bases $\mathrm{Ca}^{+2}$ e $\mathrm{Mg}^{+2}$, e CTC apresentaram-se altos, devido se tratar de um solo originalmente eutrófico.

A área com a cultura da manga (M) no Latossolo também apresentou baixo valor de $\mathrm{pH}$ e o maior teor de $\mathrm{H}+\mathrm{Al}$ para a camada de 10 a $20 \mathrm{~cm}$, também reflexo da ausência de correção do solo, o que pode afetar o desenvolvimento das plantas.

Verificam-se quanto às propriedades químicas dos dois solos estudados, que o Latossolo apresentou condições menos favoráveis ao desenvolvimento das plantas quando comparado com o Argissolo, devido ser um solo originalmente distrófico, característica dos Latossolos que apresentam baixa fertilidade natural, estes resultados estão de acordo com Queiroz (2008).

Com isso observa-se que o Latossolo encontra-se em processo de degradação química, merecendo bastante atenção quanto ao manejo e adubação para que se possa proporcionar um melhor desenvolvimento da vegetação e uma melhor cobertura do solo, evitando assim, o escoamento superficial e a erosão.

Diante do exposto, pode-se confirmar o que já havia sido evidenciado anteriormente, que o Argissolo apresenta melhores propriedades físicas e químicas em relação ao Latossolo. Salienta-se que o Latossolo representa $70 \%$ da área da Sub-Bacia, merecendo 
bastante atenção em seu manejo para que se possa evitar a sua degradação, sendo as propriedades físicas as mais degradadas.

\subsection{Escoamento superficial}

$\mathrm{Na}$ Tabela 15 estão apresentados os valores médios de precipitação, escoamento superficial e coeficiente de escoamento, dos últimos 18 anos, da Sub-Bacia em estudo.

Tabela 15. Valores de precipitação $(\mathrm{mm})$, escoamento superficial $(\mathrm{mm})$ e coeficiente de escoamento, nos últimos 18 anos, da Sub-Bacia Jardim Novo Horizonte, Ilha Solteira, SP.

\begin{tabular}{|c|c|c|c|}
\hline Anos & Precipitações & $\begin{array}{l}\text { Escoamentos } \\
\text { m - }\end{array}$ & $\begin{array}{c}\text { Coeficientes de escoamentos } \\
(\%)\end{array}$ \\
\hline $2^{\circ}$ semestre 1991 & 383,50 & 15,82 & 4 \\
\hline 1992 & 1065,90 & 29,67 & 3 \\
\hline 1993 & 1117,90 & 49,79 & 4 \\
\hline 1994 & 1016,40 & 93,91 & 9 \\
\hline 1995 & 1195,10 & 78,88 & 7 \\
\hline 1996 & 1440,60 & 90,56 & 6 \\
\hline 1997 & 1455,30 & 135,82 & 9 \\
\hline 1998 & 1567,90 & 125,48 & 8 \\
\hline 1999 & 1112,50 & 78,46 & 7 \\
\hline 2000 & 1445,40 & 135,23 & 9 \\
\hline 2001 & 1200,80 & 81,76 & 7 \\
\hline 2002 & 1071,30 & 85,70 & 8 \\
\hline 2003 & 1381,60 & 177,75 & 13 \\
\hline 2004 & 1138,20 & 61,31 & 5 \\
\hline 2005 & 1099,20 & 52,31 & 5 \\
\hline 2006 & 1437,00 & 122,94 & 9 \\
\hline 2007 & 1267,20 & 148,62 & 12 \\
\hline 2008 & 1749,70 & 225,20 & 13 \\
\hline $1^{\circ}$ semestre 2009 & 742,20 & 73,96 & 10 \\
\hline Total & 22887,70 & 1863,17 & 148 \\
\hline Média & $\mathbf{1 2 7 1 , 5 4}$ & 103,51 & 8 \\
\hline
\end{tabular}


$\mathrm{O}$ resultado encontrado referente à precipitação total do período analisado foi de $22.887,70 \mathrm{~mm}$, com um valor médio anual de $1.271,54 \mathrm{~mm}$. Para o escoamento superficial, foi observado um valor total de $1.863,17 \mathrm{~mm}$ e um valor médio anual de $103,51 \mathrm{~mm}$. Os dados apresentaram um coeficiente de determinação $\mathrm{R}^{2}$ igual a 0,56 . Entre todas as precipitações registradas no período de 18 anos, destacou-se a do ano de 2008 com $1.749,70 \mathrm{~mm}$, o qual produziu um total de água escoado superficialmente equivalente a 225,20 $\mathrm{mm}$, registrando o maior escoamento observado para o período analisado.

Ao relacionar as maiores lâminas de escoamento superficial com os respectivos valores de total precipitado, foi verificado que estas lâminas não estão necessariamente associadas aos maiores valores desta variável, com exceção ao ano de 2008 conforme descrito anteriormente. Isto mostra que a ocorrência de escoamento superficial não pode ser explicada simplesmente pela influência de uma única variável, embora muitas vezes, tenha sido observado que os maiores escoamentos estejam associados a maiores valores de precipitação. Estes resultados concordam com os obtidos por Alencar et al. (2006), que também não encontraram relação entre as maiores precipitações anuais com as maiores lâminas de escoamento superficial observadas.

Os maiores escoamentos ocorreram nos anos de 2008 com 225,20 mm, 2003 com 177,75 mm e 2007 com 148,62 mm. No ano de 2003 este valor de escoamento está associado a sétima maior precipitação observada e em 2007 a oitava maior precipitação observada para o período analisado, confirmando o que foi descrito anteriormente.

O coeficiente de escoamento é a relação entre o total precipitado e o total escoado, sendo o maior deles observado para os anos de 2008 e 2003 com 13\% que correspondem aos anos com maior escoamento superficial. O valor médio do coeficiente de escoamento superficial para o período analisado foi de $8 \%$, ou seja, do total precipitado $8 \%$ escoa sobre a superfície do solo. Queiroz (2008) estudando a mesma Sub-Bacia encontrou para o período de 2003 a 2007 valores médios de coeficiente de escoamento igual a $11 \%$.

Este pequeno valor de coeficiente de escoamento encontrado para a Sub-Bacia Jardim Novo Horizonte, pode estar associado dentre outros fatores, às boas condições de infiltração de água nos solos estudados. Uma das principais características dos Latossolos é a sua permeabilidade, isso se deve à sua estrutura granular que lhe conferem esta característica de serem solos bastante porosos e permeáveis, permitindo uma boa drenagem. Já 
os Argissolos, apresentam um caráter abrupto de variação no teor de argila no horizonte B, e esta maior concentração de argila em subsuperfície causa uma redução na velocidade de infiltração de água no solo. Apesar disso, assim como no Latossolo, o Argissolo apresentou uma boa infiltração, isso ocorreu devido às duas classes de solos apresentarem textura média, permitindo uma maior permeabilidade.

Alencar et al. (2006) estudando a influência da precipitação no escoamento superficial de uma microbacia, observaram um coeficiente de escoamento médio igual a $4 \%$. Os mesmos salientam que, este pequeno valor observado está associado às propriedades físicas do solo da microbacia, a excelente cobertura deste, e as boas condições de infiltração como observado neste trabalho.

Além disso, aproximadamente $50 \%$ da Sub-Bacia está ocupada com pastagem, que promove uma maior cobertura do solo, diminuindo assim, o impacto das gotas de chuva e o escoamento superficial. Marson e Leopoldo (1999) estudando uma microbacia na qual predominava o Latossolo com cobertura vegetal de pastagem, situação semelhante à SubBacia estudada, também encontraram um baixo coeficiente de escoamento médio, de aproximadamente $11 \%$.

O uso e o manejo do solo exercem grande influência no impacto da gota da chuva sobre a superfície do solo, e consequentemente, sobre o escoamento superficial produzido durante um evento de precipitação. Por isso, é de suma importância a adoção de práticas de manejo que promovem a conservação do solo e da água.

Pode-se observar que, nos primeiros anos analisados foram encontrados os menores coeficientes de escoamento, entre 3 e $4 \%$. Por outro lado, nos últimos anos estes coeficientes foram maiores, alcançando em 2007 e 2008, 12 e 13\% respectivamente. Maiores valores de coeficiente de escoamento superficial associados às condições de degradação de algumas propriedades do solo são preocupantes, pois com isso aumenta-se o risco de erosão.

Na Tabela 16 estão contidos os valores médios de precipitação, de evapotranspiração, de escoamento superficial observado e estimado, dos últimos 18 anos, da Sub-Bacia em estudo. 
Tabela 16. Valores de precipitação $(\mathrm{mm})$, de evapotranspiração $(\mathrm{mm})$, de escoamentos superficiais observados e calculados (mm), nos últimos 18 anos, da Sub-Bacia Jardim Novo Horizonte, Ilha Solteira, SP.

\begin{tabular}{|c|c|c|c|c|}
\hline \multirow[b]{2}{*}{ Anos } & \multirow[b]{2}{*}{ Precipitações } & \multirow[b]{2}{*}{ Evapotranspirações } & \multicolumn{2}{|c|}{ Escoamento superficial } \\
\hline & & & Observados & Calculados \\
\hline $2^{\circ}$ semestre 1991 & 383,50 & 1005,50 & 15,82 & 7,08 \\
\hline 1992 & 1065,90 & 1916,40 & 29,67 & 35,66 \\
\hline 1993 & 1117,90 & 2123,30 & 49,79 & 42,87 \\
\hline 1994 & 1016,40 & 2050,90 & 93,91 & 58,22 \\
\hline 1995 & 1195,10 & 2171,80 & 78,88 & 95,87 \\
\hline 1996 & 1440,60 & 2133,90 & 90,56 & 56,46 \\
\hline 1997 & 1455,30 & 2279,20 & 135,82 & 148,19 \\
\hline 1998 & 1567,90 & 2147,70 & 125,48 & 102,68 \\
\hline 1999 & 1112,50 & 2588,90 & 78,46 & 124,52 \\
\hline 2000 & 1445,40 & 1892,60 & 135,23 & 134,57 \\
\hline 2001 & 1200,80 & 2026,40 & 81,76 & 108,44 \\
\hline 2002 & 1071,30 & 2184,90 & 85,70 & 99,01 \\
\hline 2003 & 1381,60 & 2154,80 & 177,75 & 112,31 \\
\hline 2004 & 1138,20 & 2472,80 & 61,31 & 48,27 \\
\hline 2005 & 1099,20 & 2477,80 & 52,31 & 71,31 \\
\hline 2006 & 1437,00 & 2394,50 & 122,94 & 122,38 \\
\hline 2007 & 1267,20 & 2622,20 & 148,62 & 189,39 \\
\hline 2008 & 1749,70 & 2438,00 & 225,20 & 317,15 \\
\hline $1^{\circ}$ semestre 2009 & 742,20 & 1366,10 & 73,96 & 49,90 \\
\hline Total & 22887,70 & 40447,70 & 1863,17 & 1924,26 \\
\hline Média & 1271,54 & 2247,09 & 103,51 & 106,90 \\
\hline
\end{tabular}

Houve uma diferença no escoamento observado em relação ao escoamento calculado, sendo o escoamento observado menor que o calculado, apresentando 103,51 e 106,90 mm, respectivamente. O valor de $\mathrm{R}^{2}$ encontrado, igual a 0,56 , está associado às discrepâncias entre o escoamento observado e o calculado, pois valores de $\mathrm{R}^{2}$ próximos de 1 mostram um bom ajuste do escoamento observado com o calculado.

De acordo com Díaz et al. (2007), nestes casos em que há diferenças entre o escoamento observado e o calculado, é devido a erros sistemáticos de observação, decorrentes de falta de registros de alguns picos ou leituras efetuadas em uma só vez ao dia.

Segundo os mesmos autores, o modelo SIMHUNER se baseia em dados de precipitação e de evapotranspiração para estimar o escoamento superficial. Inicialmente a precipitação alimenta a evapotranspiração, a qual pode anular a primeira. Se a precipitação for anulada pela evapotranspiração, a bacia se encontra em fase de equilíbrio, em caso contrário, há escoamento superficial. 
Assim, a evapotranspiração representa importante fator na retirada de água do solo, pois quanto maior ela for maior será a infiltração de água no solo e menor o escoamento superficial. A evapotranspiração média nos últimos 18 anos para a Sub-Bacia estudada foi de 2.247,09 mm, o qual juntamente com as boas condições de infiltração de água nos solos resultou em baixos coeficientes de escoamento.

A simulação hidrológica da variação do escoamento superficial dos solos da Sub-Bacia Jardim Novo Horizonte nos últimos 18 anos encontra-se nas Figuras 14, $15,16,17$ e 18.

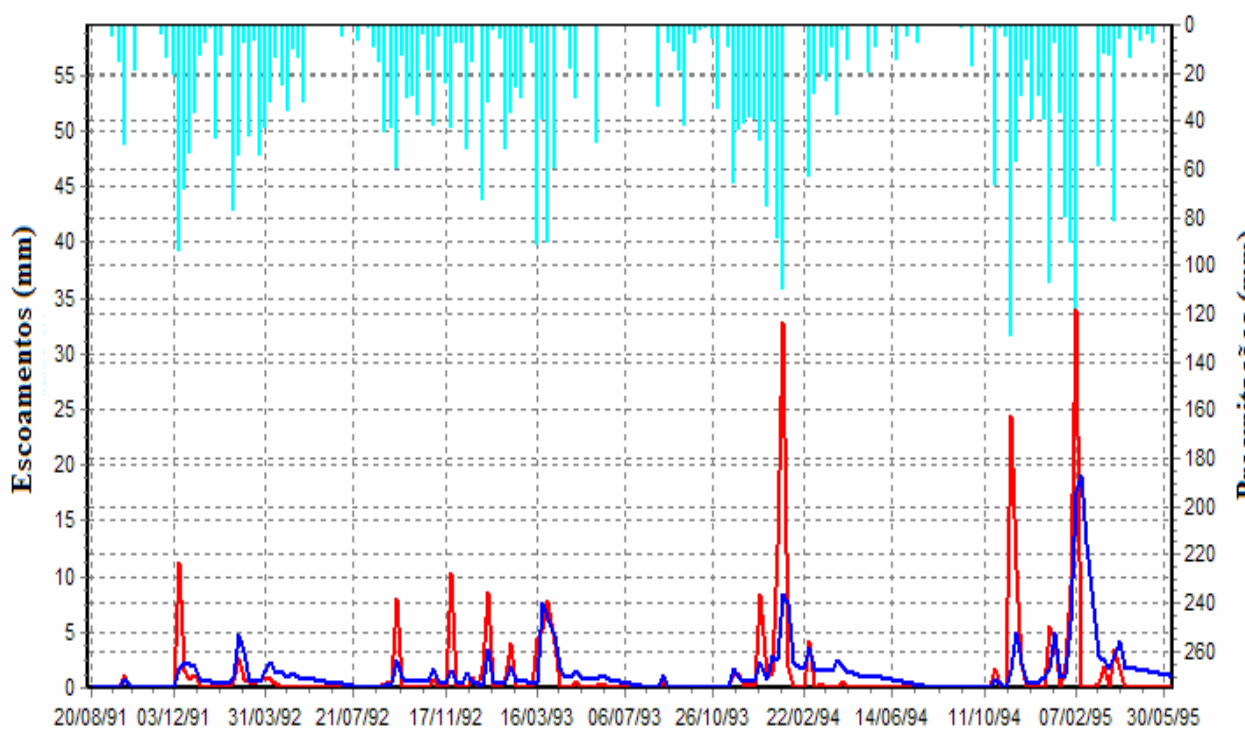

Legenda

- Precipitação

- Escoamento observado

- Escoamento calculado

Figura 14. Simulação hidrológica da variação do escoamento superficial nos solos da SubBacia Jardim Novo Horizonte, Ilha Solteira-SP, para os períodos de 20/08/1991 a 30/05/1995. 

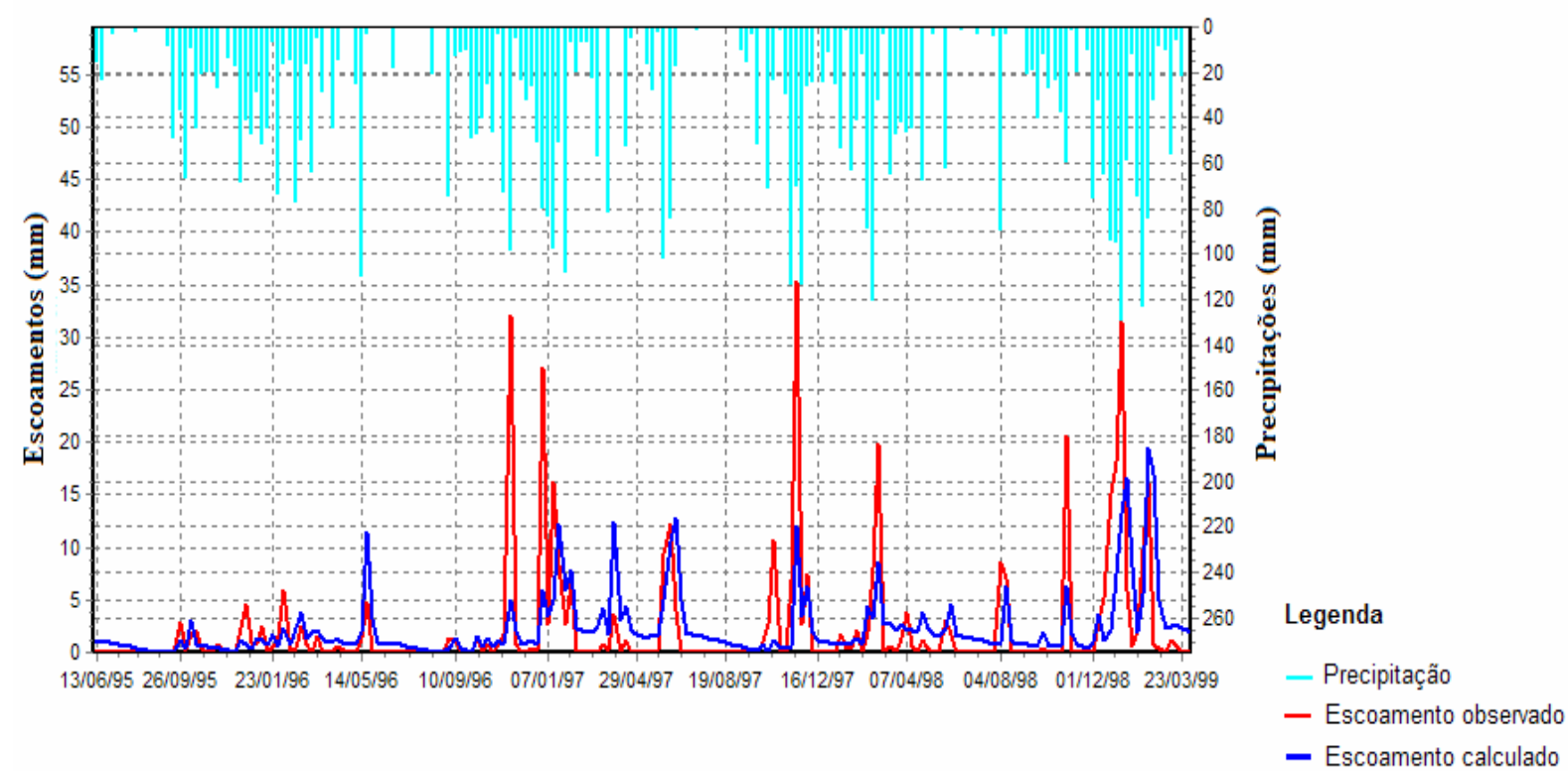

Figura 15. Simulação hidrológica da variação do escoamento superficial nos solos da SubBacia Jardim Novo Horizonte, Ilha Solteira-SP, para os períodos de 13/06/1995 a 23/03/1999.

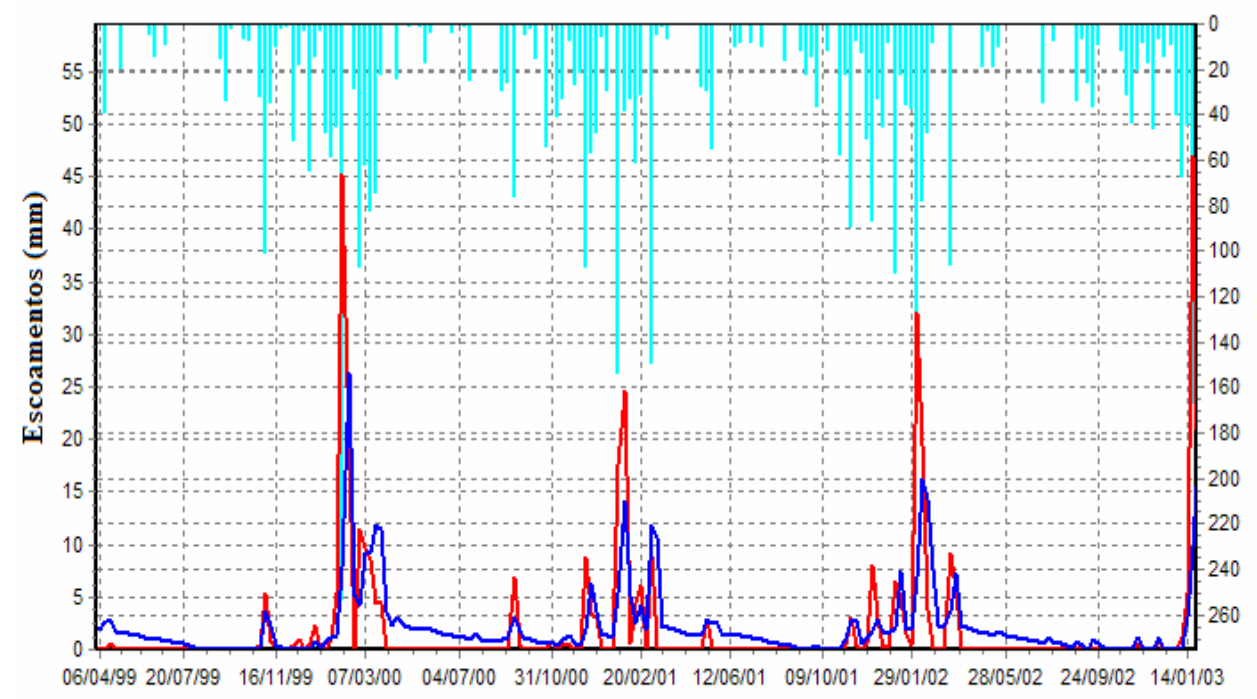

Legenda

Figura 16. Simulação hidrológica da variação do escoamento superficial nos solos da SubBacia Jardim Novo Horizonte, Ilha Solteira-SP, para os períodos de 06/04/1999 a $14 / 01 / 2003$. 


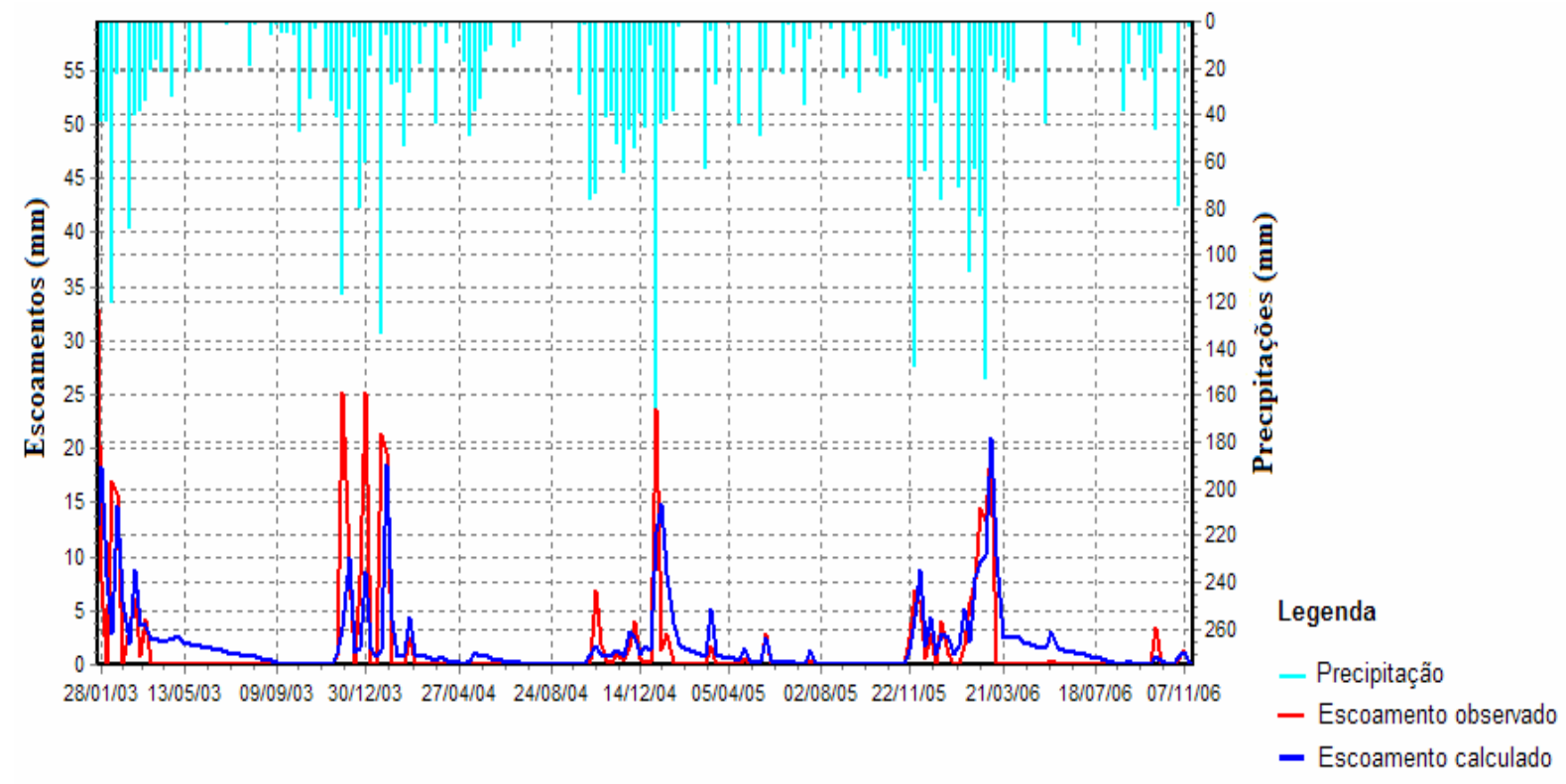

Figura 17. Simulação hidrológica da variação do escoamento superficial nos solos da SubBacia Jardim Novo Horizonte, Ilha Solteira-SP, para os períodos de 28/01/2003 a 07/11/2006.

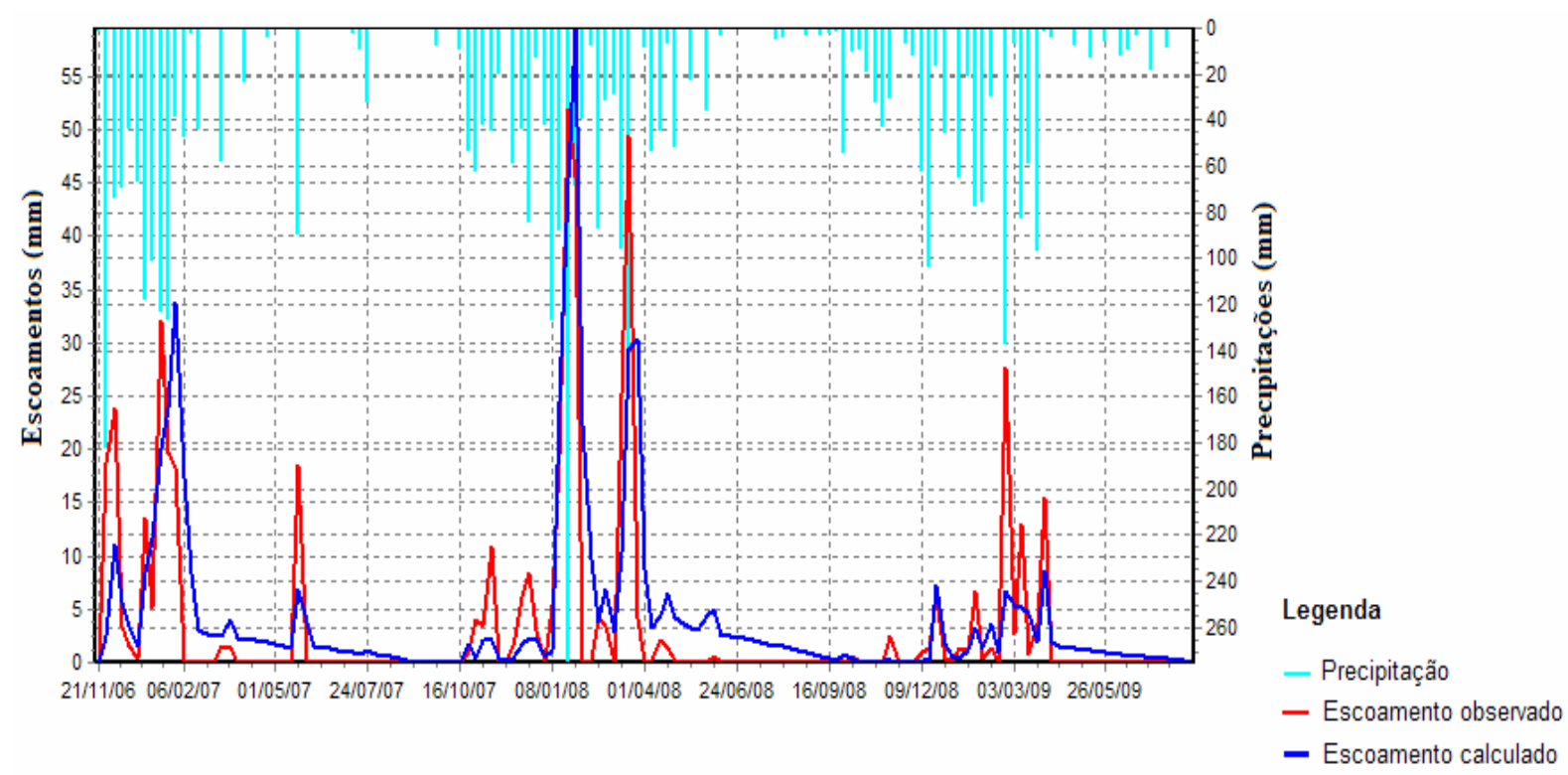

Figura 18. Simulação hidrológica da variação do escoamento superficial nos solos da SubBacia Jardim Novo Horizonte, Ilha Solteira-SP, para os períodos de 21/11/2006 a 28/05/2009. 
As Figuras 14, 15, 16, 17 e 18 permitem observar o contraste entre o escoamento observado e o calculado discutido anteriormente. Como observado, nos anos de 2003 e 2008 houve o maior escoamento superficial, correspondendo ao período de 14/01/2003 a 28/01/2003 (Figuras 16 e 17) e 08/01/2008 a 01/04/2008 (Figura 18). Verifica-se também um maior escoamento superficial no período compreendido entre 16/11/1999 a 07/03/2000 (Figura 16). Os quais correspondem ao período chuvoso da região que compreende principalmente os meses de outubro a março.

Silva (2006) avaliando o escoamento superficial em uma sub-bacia localizada no Estado de Minas Gerais, observou para o período de outubro de 2004 a março de 2005 um aumento significativo no escoamento superficial devido ao aumento da concentração de chuvas neste período, que correspondem ao período chuvoso, como observado neste trabalho.

De acordo com Santos et al. (2009), no período chuvoso a precipitação pode ser irregular, havendo dias ou horas de chuva intensa, intercalados de períodos curtos de estiagem, estas chuvas intensas favorecem o escoamento superficial e consequentemente a infiltração de água no solo é reduzida.

Isto ocorre, pois a infiltração de água no solo irá ocorrer até que a capacidade do solo em armazenar água seja excedida, e quando isso acontece o processo de infiltração de água cessa e o escoamento superficial se inicia. Além disso, em períodos chuvosos o teor de água no solo permanece alto e isso ocasiona uma diminuição na infiltração de água no solo.

Por outro lado, Silva (2006) salienta que as precipitações em período seco, normalmente são oriundas de frentes frias, com baixa intensidade e longa duração. Aliado a isso, neste período o teor de água no solo já se encontra consideravelmente baixo, situação esta que não propicia a geração de escoamentos superficiais altos.

Com isso, pode-se afirmar que, os baixos valores de coeficiente de escoamento observados para os solos indicam que apenas uma pequena parte da precipitação que chega sobre a Sub-Bacia será convertida em escoamento superficial, significando que a mesma apresenta uma baixa tendência ao escoamento superficial e boa capacidade de drenagem se adequadamente manejada. 
Estes resultados indicam que a Sub-Bacia Jardim Novo Horizonte apresenta naturalmente baixo potencial de escoamento superficial. Mas devido à degradação de algumas propriedades do solo, deve-se tomar bastante atenção quanto às práticas de manejo e conservação do solo para que estas propriedades sejam recuperadas, evitando assim, o aumento do escoamento superficial. 


\section{CONCLUSÕES}

De acordo com os resultados obtidos pôde-se concluir que:

- A degradação de algumas propriedades físicas e químicas do Latossolo pelo uso e manejo, causa maior risco de erosão para a Sub-bacia Jardim Novo Horizonte.

- As taxas de infiltração da água nos solos moderadas e rápidas promovem baixo escoamento superficial.

- A Sub-Bacia estudada apresentou boa capacidade de drenagem e baixo escoamento superficial, porém devido à degradação de algumas propriedades dos solos que afetam a dinâmica da água neste, sobretudo no Latossolo, algumas áreas apresentam risco de erosão. 


\section{REFERÊNCIAS BIBLIOGRÁFICAS}

ALENCAR, D. B. S.; SILVA, C. L.; OLIVEIRA, C. A. S. Influência da precipitação no escoamento superficial em uma microbacia hidrográfica do Distrito Federal. Engenharia Agrícola, Jaboticabal, SP, v. 26, n. 1, p. 103-112, 2006.

ANGERS, D.A.; MEHUYS, G.R. Aggregate stability to water. In: CARTER, M. R. Soil sampling and methods of analysis. Boca Raton, Florida: Lewis Publishers, 2000. p. 529-539.

AVANZINI, J. C. Modelagem do escoamento superficial e erosão hídrica em uma microbacia hidrográfica na região dos tabuleiros costeiros. 2005. 68 f. Dissertação (Mestrado em Agronomia/Solos e Nutrição de Plantas) - Universidade Federal de Lavras, Lavras, MG, 2005.

BERTONI, J.; LOMBARDI NETO, F. Conservação do solo. São Paulo: Editora Ícone, 1990. $355 \mathrm{p}$.

BRANDÃO, V. S. et al. Infiltração de água no solo. 3 ed. Viçosa: UFV, 2009. 120 p. CAMARGO, O. A.; ALLEONI, L. R. F. Compactação do solo e o desenvolvimento de plantas. Piracicaba: ESALQ, 1997. 132 p. 
CARNEIRO, M. A. C. et al. Atributos físicos, químicos e biológicos de solo de cerrado sob diferentes sistemas de uso e manejo. Revista Brasileira de Ciência do Solo, Viçosa, MG, v. 33, p. 147-157, 2009.

CARVALHO, N. O. Hidrossedimentologia prática. Rio de Janeiro: Companhia de Pesquisa em Recursos Minerais, 1994. 602p.

CASTRO FILHO, C.; MUZILLI, O.; PADANOSCHI, A. L. Estabilidade dos agregados e sua relação com o teor de carbono orgânico num Latossolo Roxo distrófico, em função de sistemas de plantio, rotação de culturas e métodos de preparo das amostras. Revista Brasileira de Ciência do Solo, Viçosa, MG, v. 22, n. 3, p. 527-538, 1998.

CAVENAGE, A. et al. Alterações nas propriedades físicas de um Latossolo Vermelho-escuro sob diferentes culturas. Revista Brasileira de Ciência do Solo, Viçosa, MG, v. 23, p. 997 1003, 1999.

CECONI, D. E. et al. Influência do uso do solo nas propriedades físicas na microbacia hidrográfica do Lageado Biguá, Alecrim-RS. In: CONGRESSO BRASILEIRO DE CIÊNCIA DO SOLO, 31, 2007, Gramado. Anais... Gramado: Sociedade Brasileira de Ciência do Solo, 2007. CD-ROM.

CENTURION, J. F.; CARDOSO, J. P.; NATALE, W. Efeito de formas de manejo em algumas propriedades físicas e químicas de um Latossolo Vermelho em diferentes agroecossistemas. Revista Brasileira de Engenharia Agrícola e Ambiental, Campina Grande, PB, v. 5, n. 2, p. 254-258, 2001.

CURI, N. et al. Vocabulário de ciência do solo. Campinas: Sociedade Brasileira de Ciência do Solo, 1993. p. 90. 
DÍAZ, E. et al. Evalución agrohidrológica para Riego: su estúdio en Entre Ríos. Paraná: Universidad Nacional de Entre Ríos, 2007. 212 p.

DUARTE, S. M. A. et al. Levantamento de solo e declividade da microbacia hidrográfica Timbaúba no Brejo Paraibano, através de técnicas de fotointerpretação e SIG. Revista de Biologia e Ciência da Terra, Campina Grande, PB, v. 4, n. 2, 2004.

EMBRAPA. Manual de métodos de análise de solo. 2. ed. Rio de Janeiro: EMBRAPACNPS, 1997. 212 p.

FERREIRA, M. M. et al. Física do solo. Textos Acadêmicos. Lavras: Editora UFLA, 2003. 79 p.

FE/IS/UNESP. Clima do município de Ilha Solteira, SP. Disponível em: $<$ http://www.agr.feis.unesp.br/clima.php>. Acesso em: 30 ago. 2009.

FIGUEIREDO, C. C.; RAMOS, M. L. G.; TOSTES, R. Propriedades físicas e matéria orgânica de um Latossolo Vermelho sob sistemas de manejo e cerrado nativo. Bioscience, Uberlândia, MG, v. 24, n. 3, p. 24-30, 2008.

FIGUEIREDO, C. C. et al. Propriedades físico-hídricas em Latossolo do Cerrado sob diferentes sistemas de manejo. Revista Brasileira de Engenharia Agrícola e Ambiental, Campina Grande, PB, v. 13, n. 2, p. 146-151, 2009.

FILIZOLA, H. F.; GOMES, M. A. F.; SOUZA, M.D. Manual de procedimentos de coleta de amostras em áreas agrícolas para análise de qualidade ambiental: solo, água e sedimentos. Jaguariúna: Embrapa Meio Ambiente, 2006. 169 p.

GONÇALVES, C. S. et al. Qualidade da água numa microbacia hidrográfica de cabeceira situada em região produtora de fumo. Revista Brasileira de Engenharia Agrícola e Ambiental, Campina Grande, PB, v. 9, n. 3, p. 391-399, 2005. 
INÁCIO, E. S. B. et al. Quantificação da erosão em pastagem com diferentes declividades na microbacia do Ribeirão Salomea. Revista Brasileira de Engenharia Agrícola e Ambiental, Campina Grande, PB, v. 11, n. 4, p. 355-360, 2007.

KIEHL, E. J. Manual de edafologia. São Paulo: Agronômica Ceres, 1979. 262p.

KIRCHNER, H. S. et al. Índices topográficos do potencial de erosão em estradas florestais. In: RODRIGUES, V.A.; BUCCI, L.A. Manejo de microbacias hidrográficas: experiências nacionais e internacionais. Botucatu: FEPAF, 2006. p. 188-199.

LIMA, P. M. P.; ANDRADE, H. Erodibilidade entressulcos e atributos de solos com B textural e B latossólico do município de Lavras - MG. Revista Brasileira de Ciência do Solo, Viçosa, MG, v. 25, n. 2, p. 463-474, 2001.

MAGRINI, A.; SANTOS, M. A. Gestão ambiental de bacias hidrográficas. Rio de Janeiro: Instituto Virtual Internacional de Mudanças Globais, 2001. 271 p.

MARCHÃO, R. L. et al. Qualidade física de um Latossolo Vermelho sob sistemas de integração lavoura-pecuária no Cerrado. Pesquisa Agropecuária Brasileira, Brasília, DF, v. 42, n. 6, p. 873-882, 2007.

MARCHÃO, R. L. Integração lavoura-pecuária num latossolo do cerrado: impacto na física, matéria orgânica e macrofauna. 2007. 153f. Tese (Doutorado em Agronomia/Solo e Água) - Escola de Agronomia e Engenharia de Alimentos, Universidade Federal de Goiás, Goiânia, GO, 2007.

MARSON, E. A.; LEOPOLDO, P. R. Caracterização quantitativa de escoamento em microbacia na região central do estado de São Paulo. Energia na Agricultura, v. 14, n. 4, p. $1-8,1999$. 
MATIAS, S. S. R. et al. Atributos físicos de um Latossolo Vermelho submetido a diferentes usos. Revista Ciência Agronômica, Fortaleza, CE, v. 40, n. 3, p. 331-338, 2009.

MELLO, C.R. Estudo hidrológico em microbacia hidrográfica com regime de escoamento efêmero. 2003. 133 f. Tese (Doutorado em Agronomia/Solos e Nutrição de Plantas) Universidade Federal de Lavras, Lavras, MG, 2003.

MESQUITA, M. G. B. F.; MORAES, S. O. A dependência entre a condutividade hidráulica saturada e atributos físicos do solo. Ciência Rural, Santa Maria, RS, v. 34, n. 3, p. 963-969, 2004.

OLIVEIRA, J. B. Solos do Estado de São Paulo: descrição das classes registradas no mapa pedológico. Boletim do Instituto Agronômico de Campinas, IAC, Campinas, n. 45, 1999. $112 \mathrm{p}$.

OLIVEIRA, J. B. et al. Mapa pedológico do Estado de São Paulo - legenda expandida. Campinas: IAC, 1999. 63p.

OTTONI FILHO, T. B. Uma classificação físico-hídrica dos solos. Revista Brasileira de Ciência do Solo, Viçosa, MG, v. 27, p. 211-222, 2003.

PAIVA, E. M. C. Evolução de processo erosivo acelerado em trecho do Arroio Vacacai Mirim. Revista Brasileira de Recursos Hídricos, Porto Alegre, RS, v. 6, n. 2, p. 129-135, 2001.

PEREIRA, S. B. et al. Desprendimento e arraste do solo pelo escoamento superficial. Revista Brasileira de Engenharia Agrícola e Ambiental, Campina Grande, PB, v. 7, n. 3, p. 423 429, 2003. 
PINHEIRO, A.; TEIXEIRA, L. P.; KAUFMANN, V. Capacidade de infiltração de água em solos sob diferentes usos e práticas de manejo agrícola. Ambi-água, Taubaté, SP, v. 4, n. 2, p. 188-199, 2009.

PIROLI, E. L. et al. Análise do uso da terra na microbacia do arroio do meio - Santa Maria RS, por sistema de informações geográficas e imagem de satélite. Ciência Rural, Santa Maria, RS, v. 32, n. 3, p. 407-413, 2002.

PORTUGAL, A. F. et al. Atributos químicos e físicos de um Cambissolo háplico distrófico sob diferentes usos na zona da mata mineira. Revista Brasileira de Ciência do Solo, Viçosa, MG, v. 32, p. 249-258, 2008.

PRUSKI, F. F.; RODRIGUES, L. N.; SILVA, D. D. Modelo hidrológico para estimativa do escoamento superficial em áreas agrícolas. Revista Brasileira de Engenharia Agrícola e Ambiental, Campina Grande, PB, v. 5, n. 2, p. 301-307, 2001.

PRUSKI, F. F.; BRANDÃO, V.S.; SILVA, D. D. Escoamento superficial. 2. ed. Viçosa: UFV, 2008. $87 \mathrm{p}$.

QUEIROZ, H. A. Caracterização fisiográfica e de alguns atributos físicos e químicos dos solos da microbacia Jardim Novo Horizonte, em Ilha Solteira, SP. 2008. 61 f. Dissertação (Mestrado em Agronomia/Sistema de Produção) - Faculdade de Engenharia, Universidade Estadual "Júlio de Mesquita Filho", Ilha Solteira, SP, 2008.

RAIJ, B. V. et al. Análise Química para avaliação da fertilidade de solos tropicais. Campinas: Instituto Agronômico, 2001. 285p.

RANIERI, B. L.; ESPINOSA, E.; MORTATTI, J. Erosão mecânica e transporte de sedimentos em alguns dos maiores rios do mundo. In: MORTTATI, J.; PROBST, J.L. Hidrogeoquímica de bacias de drenagem. Piracicaba: CENA, 1998. 235p. 
RANZINI, M. Modelagem hidrológica de uma microbacia com mata atlântica: simulação do Corte Raso. In: RODRIGUES, V.A.; BUCCI, L.A. Manejo de microbacias hidrográficas: experiências nacionais e internacionais. Botucatu: FEPAF, 2006. p. 103-119.

REICHARDT, K. Dinâmica da matéria e energia nos ecossistemas. 2.ed. Piracicaba: ESALQ, Departamento de Física e Meteorologia, 1996. 160p.

REINERT, D. J.; REICHERT, J. M. Propriedades físicas do solo. Apostila didática. UFSM, Santa Maria, 2006. 18p.

REYNOLDS, W. D.; ELRICK, D. E. In situ measurement of field-satured hydraulic conductivity, sorptivity, and the - parameter using the Guelph permeameter. Soil Science, Baltimore, v. 140, n. 4, p. 292-302, 1985.

RIBEIRO, K. D. Influência da distribuição de vazios na condutividade hidráulica do solo saturado. 2005. 56 f. Dissertação (Mestrado em Engenharia Agrícola/Irrigação e Drenagem) Universidade Federal de Lavras, Lavras, MG, 2005.

RIGHETTO, A.M. Hidrologia e recursos hídricos. São Carlos: EESC-USP, 1998. 840 p.

SALTON, J. C. et al. Agregação e estabilidade de agregados do solo em sistemas agropecuários em Mato Grosso do Sul. Revista Brasileira de Ciência do Solo, Viçosa, MG, v. 32, p. 11-21, 2008.

SANTOS, K. S.; LEMES, S. S.; ROMÃO, P. A. Uso do solo e escoamento superficial na bacia do córrego da pedreira em Goiânia (GO): uma análise a partir de imagens de alta resolução espacial. In: SIMPÓSIO BRASILEIRO DE SENSORIAMENTO REMOTO, 14, 2009, Natal. Anais... Natal: INPE, 2009. p. 859-866.

SCHLOTZHAVER, S.D.; LITTELL, R. C. SAS: System for elementary statistical analysis. 2.ed. Cary: SAS, 1997. 905p. 
SILVA, A.C. Relação entre voçorocas e solos na região de Lavras (MG). 1990. $124 \mathrm{f}$.

Dissertação (Mestrado em Agronomia/Solos e Nutrição de Plantas) - Universidade Federal de Lavras, Lavras, MG, 1990.

SILVA, I. F.; MIELNICZUK, J. Sistemas de cultivo e características do solo afetando a estabilidade de agregados. Revista Brasileira de Ciência do Solo, Viçosa, MG, v. 22, p. 311$317,1998$.

SILVA, J. R. Compactação do solo exercida por tráfego de colheita e transporte de madeira. 2003. 134 f. Tese (Doutorado em Agronomia/Energia na Agricultura) - Faculdade de Ciências Agronômicas, Universidade Estadual “Júlio de Mesquita Filho”, Botucatu, SP, 2003.

SILVA, M. A. S. et al. Atributos físicos do solo relacionados ao armazenamento de água em um Argissolo Vermelho sob diferentes sistemas de preparo. Ciência Rural, Santa Maria, RS, v. 35 , n. 3 , p. 544-552, 2005.

SILVA, P. M. O. Modelagem do escoamento superficial e erosão na sub-bacia hidrográfica do ribeirão marcela, Alto Rio Grande, MG. 2006. 155 f. Tese (Doutorado em Engenharia Agrícola/Irrigação e Drenagem) - Universidade Federal de Lavras, Lavras, MG, 2006.

SILVA, A. M.; SCHULZ, H. E.; CAMARGO, P.B. Erosão e hidrossedimentologia em bacias hidrográfica. 2. ed. São Carlos: Editora Rima, 2007. 158 p.

SILVEIRA, A. L. L. A. Ciclo hidrológico e bacia hidrográfica. In: TUCCI, C. E. M.

Hidrologia: Ciência e Aplicação. 2. ed. Porto Alegre: ABRH, 2001. p. 35-52.

SOIL CONSERVATION SERVICE. National engineering handbook. Washington: USDA United States Department of Agriculture, 1972. n.p. (Section 4: Hydrology). 
SOIL SURVEY STAFF. Soil survey manual. Washington: Soil Conservation Service United States Department of Agriculture. Gov. Print. Office, 1993. 437 p. (Handbook, 18).

SOUTO, A. R.; CRESTANA, S. Identificação das áreas potenciais de produção de sedimento com o modelo AGNPS e técnicas de SIG em uma microbacia hidrográfica. Revista Brasileira de Engenharia Agrícola e Ambiental, Campina Grande, PB, v. 4, n. 3, p. 429-435, 2000.

SOUZA, Z. M.; ALVES, M. C. Movimento de água e resistência à penetração em um Latossolo Vermelho distrófico de cerrado, sob diferentes usos e manejos. Revista Brasileira de Engenharia Agrícola e Ambiental, Campina Grande, PB, v. 7, n. 1, p. 18-23, 2003.

STHRALER, A. N. Quantitative analysis of watershed geomorphology. American Geophysical Union, Transactions, v. 38, p. 913-920, 1957.

TUCCI, C. E. M. Escoamento superficial. In: TUCCI, C. E. M. Hidrologia: Ciência e Aplicação. 2. ed. Porto Alegre: ABRH, 2001. p. 391-441.

VAN GENUCHTEN, M. T. A closed-form equation for predicting the hydraulic conductivity of unsaturated soils. Soil Science Society America Journal, Madison, v. 44, p. 892-898, 1980.

VIEIRA, S. R.; REYNOLDS, W. D.; TOPP, G. C. Spatial variability of hydraulic properties in a highly structured clay soil. In: WIERANGA, P. J.; BACHELET, D. Of flow and transport models for the unsaturated zone. Las Cruces: Department of Agronomy and Horticulture, New Mexico State University, 1988. p. 471-483.b

ZHANG, R. Determination of soil sorptivity and hydraulic conductivity from the disk infiltrometer. Soil Science Society America Journal, Madison, v. 61, p. 1024-1030, 1997. 
APÊNDICE 
Apêndice 1: Parâmetros de Van Genuchten para 12 classes texturais e valores de sucção de 0,5 a $6,0 \mathrm{~cm}$.

\begin{tabular}{lccccccc}
\hline \multicolumn{1}{c}{ Textura } & & & & $\mathbf{h}_{\mathbf{0}}$ & & & \\
& $-0,5$ & $-1,0$ & $-2,0$ & $-3,0$ & $-4,0$ & $-5,0$ & $-6,0$ \\
\hline Arenosa & 2,9 & 2,5 & 1,8 & 1,3 & 0,9 & 0,7 & 0,5 \\
Areia franca & 3,0 & 2,8 & 2,5 & 2,2 & 1,9 & 1,6 & 1,4 \\
Franco-arenosa & 4,0 & 4,0 & 4,0 & 4,0 & 4,0 & 4,1 & 4,1 \\
Franco & 5,6 & 5,8 & 6,4 & 7,0 & 7,7 & 8,4 & 9,2 \\
Siltosa & 8,1 & 8,3 & 8,9 & 9,5 & 10,1 & 10,8 & 11,5 \\
Franco-siltosa & 7,2 & 7,5 & 8,1 & 8,7 & 9,4 & 10,1 & 10,9 \\
Franco-argilo-arenosa & 3,3 & 3,6 & 4,3 & 5,2 & 6,3 & 7,6 & 9,1 \\
Franco-argilosa & 6,0 & 6,2 & 6,8 & 7,4 & 8,0 & 8,7 & 9,5 \\
Franco-argilo-siltosa & 8,1 & 8,3 & 8,7 & 9,1 & 9,6 & 10,1 & 10,6 \\
Argilo-arenosa & 3,4 & 3,6 & 4,2 & 4,8 & 5,5 & 6,3 & 7,2 \\
Argilo-siltosa & 6,2 & 6,3 & 6,5 & 6,7 & 6,9 & 7,1 & 7,3 \\
Argilosa & 4,1 & 4,2 & 4,4 & 4,6 & 4,8 & 5,1 & 5,3 \\
\hline
\end{tabular}

Adaptado de Van Genuchten (1980).

Apêndice 2: Classes de permeabilidade do solo à água $\left(\mathrm{cm} \mathrm{h}^{-1}\right)$.

\begin{tabular}{lc}
\hline \multicolumn{1}{c}{ Classe } & Permeabilidade \\
\hline Rápida & $>25,4$ \\
Moderada a rápida & $25,4-12,7$ \\
Moderada & $12,7-6,35$ \\
Lenta a moderada & $6,35-2,0$ \\
Lenta & $2,0-0,5$ \\
Muito lenta & $<0,5$ \\
\hline
\end{tabular}

Adaptado de Soil Survey Staff (1993). 
Apêndice 3: Valores de CN para bacias com ocupação agrícola.

\begin{tabular}{|c|c|c|c|c|c|}
\hline \multirow[b]{2}{*}{ Uso do Solo } & \multirow[b]{2}{*}{ Superfície } & \multicolumn{4}{|c|}{ Tipo de Solo } \\
\hline & & $\mathbf{A}$ & B & $\mathbf{C}$ & D \\
\hline \multirow[t]{2}{*}{ Solo Lavrado } & Com sulcos retilíneos & 77 & 86 & 91 & 94 \\
\hline & Em fileiras retas & 70 & 80 & 87 & 90 \\
\hline Plantações & Em curvas de nível & 67 & 77 & 83 & 87 \\
\hline \multirow{2}{*}{ regulares } & Terraceado em nível & 64 & 76 & 84 & 88 \\
\hline & Em fileiras retas & 64 & 76 & 84 & 88 \\
\hline \multirow{3}{*}{$\begin{array}{l}\text { Plantações de } \\
\text { cereais }\end{array}$} & Em curvas de nível & 62 & 74 & 82 & 85 \\
\hline & Terraceado em nível & 60 & 71 & 79 & 82 \\
\hline & Em fileiras retas & 62 & 75 & 83 & 87 \\
\hline \multirow{5}{*}{$\begin{array}{l}\text { Plantações de } \\
\text { legumes ou } \\
\text { cultivados }\end{array}$} & Em curvas de nível & 60 & 72 & 81 & 84 \\
\hline & Terraceado em nível & 57 & 70 & 78 & 89 \\
\hline & Pobres & 68 & 79 & 86 & 89 \\
\hline & Normais & 49 & 69 & 79 & 94 \\
\hline & Boas & 39 & 61 & 74 & 80 \\
\hline \multirow[t]{3}{*}{ Pastagens } & Pobres, em curva de nível & 47 & 67 & 81 & 88 \\
\hline & Normais, em curva de nível & 25 & 59 & 75 & 83 \\
\hline & Boas, em curva de nível & 6 & 35 & 70 & 79 \\
\hline Campos & Normais & 30 & 58 & 71 & 78 \\
\hline \multirow[t]{3}{*}{ permanentes } & $\begin{array}{l}\text { Esparsas, de baixa } \\
\text { transpiração }\end{array}$ & 45 & 66 & 77 & 83 \\
\hline & Normais & 36 & 60 & 73 & 79 \\
\hline & Densas, de alta transpiração & 25 & 55 & 70 & 77 \\
\hline Chácaras & Normais & 56 & 75 & 86 & 91 \\
\hline Estradas de & Más & 72 & 82 & 87 & 89 \\
\hline terra & de superfície dura & 74 & 84 & 90 & 92 \\
\hline \multirow[t]{4}{*}{ Florestas } & $\begin{array}{l}\text { Muito esparsas, baixa } \\
\text { transpiração }\end{array}$ & 56 & 75 & 86 & 91 \\
\hline & Esparsas & 46 & 68 & 78 & 84 \\
\hline & Densas, alta transpiração & 26 & 52 & 62 & 69 \\
\hline & Normais & 36 & 60 & 70 & 76 \\
\hline
\end{tabular}

Tucci (2001). 